\title{
Burkina Faso: 2007 Article IV Consultation, First Review Under the Poverty Reduction and Growth Facility, Request for Access Augmentation, Requests for Waivers of Nonobservance of Performance Criteria, and Request for Modification of Performance Criteria-Staff Report; Public Information Notice and Press Release on the Executive Board Discussion; and Statement by the Executive Director for Burkina Faso
}

\begin{abstract}
Under Article IV of the IMF's Articles of Agreement, the IMF holds bilateral discussions with members, usually every year. In the context of a combined discussion of the 2007 Article IV consultation with Burkina Faso, first review under the Poverty Reduction and Growth Facility, request for access augmentation, requests for waivers of nonobservance of performance criteria, and request for modification of performance criteria, the following documents have been released and are included in this package:
\end{abstract}

- $\quad$ The staff report for the combined 2007 Article IV consultation, First Review Under the Poverty Reduction and Growth Facility, Request for Access Augmentation, Requests for Waivers of Nonobservance of Performance Criteria, and Request for Modification of Performance Criteria, prepared by a staff team of the IMF, following discussions that ended on October 4, 2007, with the officials of Burkina Faso on economic developments and policies. Based on information available at the time of these discussions, the staff report was completed on December 20, 2007. The views expressed in the staff report are those of the staff team and do not necessarily reflect the views of the Executive Board of the IMF.

- $\quad$ A Public Information Notice (PIN) and Press Release, summarizing the views of the Executive Board as expressed during its January 9, 2008, discussion of the staff report on issues related to the Article IV consultation and the IMF arrangement, respectively.

- $\quad$ A statement by the Executive Director for Burkina Faso.

The documents listed below have been or will be separately released.

Letter of Intent sent to the IMF by the authorities of Burkina Faso*

Memorandum of Economic and Financial Policies by the authorities of

Burkina Faso*

Technical Memorandum of Understanding*

*Also included in Staff Report

The policy of publication of staff reports and other documents allows for the deletion of market-sensitive information.

$$
\begin{gathered}
\text { Copies of this report are available to the public from } \\
\text { International Monetary Fund • Publication Services } \\
70019^{\text {th }} \text { Street, N.W. • Washington, D.C. 20431 } \\
\text { Telephone: (202) 623-7430 • Telefax: (202) 623-7201 } \\
\text { E-mail: publications@imf.org • Internet: http://www.imf.org }
\end{gathered}
$$

Price: $\$ 18.00$ a copy

\author{
International Monetary Fund \\ Washington, D.C.
}



INTERNATIONAL MONETARY FUND

BURKINA FASO

\section{Article IV Consultation, First Review Under the Poverty Reduction and Growth Facility, Request for Access Augmentation, Requests for Waivers for Nonobservance of Performance Criteria, and Request for Modification of Performance Criteria}

Prepared by the African Department

(In consultation with other departments)

Approved by Thomas Krueger and Mark Plant

December 20, 2007

Discussions: Discussions were held in Ouagadougou September 19-October 4, 2007. The staff met with Prime Minister Tertius Zongo, Minister of Finance Jean-Baptiste Compaoré, National Director of the Central Bank of West African States (BCEAO) Bolo Sanou, and other senior government officials and with donors, private sector representatives, union leaders, and civil society organizations. The mission comprised Messrs. Petri (head), Basdevant, Dwight, Gottschalk (all AFR), and Zejan (resident representative). Mr. Tall (OED) attended the policy meetings.

PRGF arrangement: The three-year PRGF arrangement was approved on April 23, 2007 with a total access of SDR 6.02 million. Burkina Faso's outstanding purchases and loans from the Fund at end-October 2007 amounted to SDR 23.72 million, 39.4 percent of quota. 


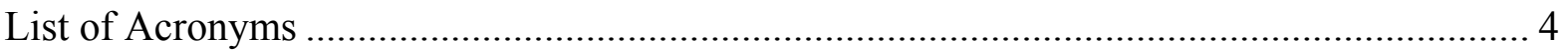

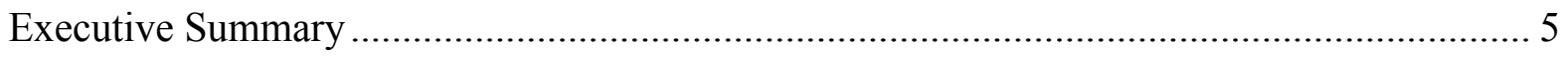

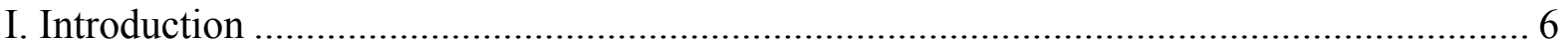

A. Developments Since the 2005 Article IV Consultations ……………………………...... 6

B. Recent Economic Developments and Outlook ……………………........................... 7

II. Surveillance Priorities ............................................................................................ 9

A. External Competitiveness …………………………............................................ 9

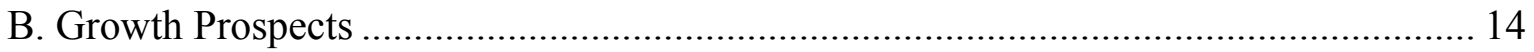

C. Public Sector Efficiency....................................................................................... 16

D. Policy Implications Going Forward...................................................................... 18

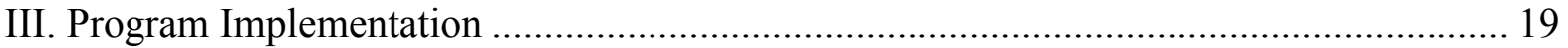

A. Program Implementation and Policies for the Remainder of 2007............................... 19

B. Economic and Structural Policies for 2008 and the Medium Term .............................. 21

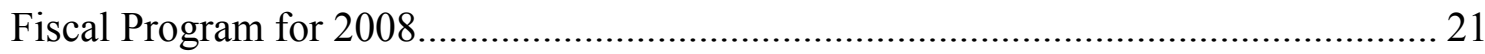

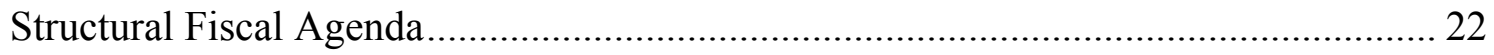

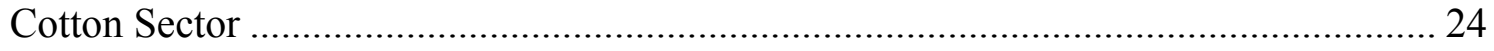

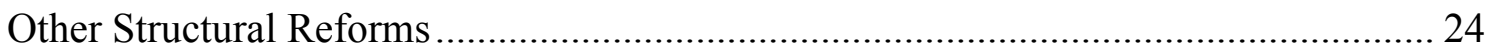

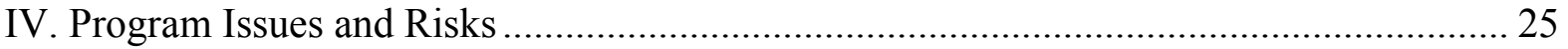

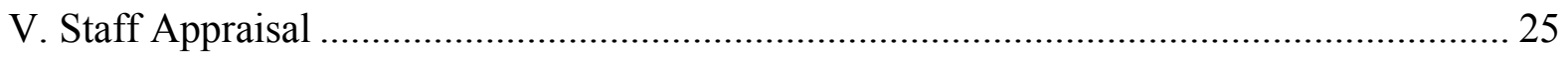

\section{Text Tables}

1. Developments Since the 2005 Article IV Consultation...................................................6

2. Post-MDRI Debt Indicators for Burkina Faso and WAEMU Countries, 2007-27 ...........9

3. Financing Sources for the Current Accent Deficit.....................................................12

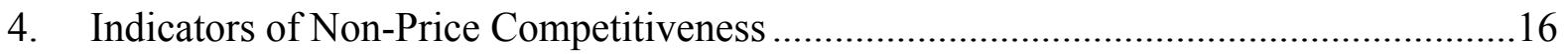

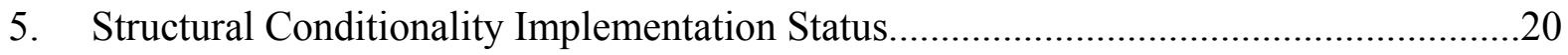

6. Summary of Government Operations, 2006-08 ………............................................22

Figures

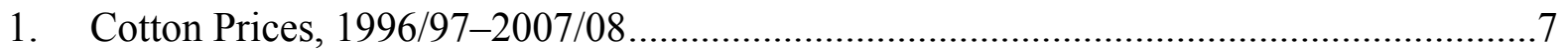

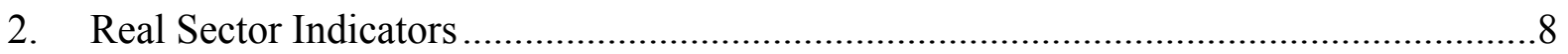

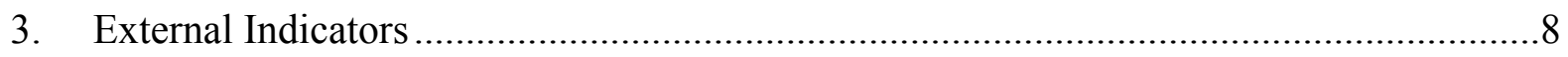

4. World Cotton Prices and Euro/Dollar Exchange Rate....................................................10

5. Indicators of Real Exchange Rate Competitiveness ........................................................

6. Current Account Balances and Debt-to-Export Ratios...................................................12

7. Baseline Current Account and Savings-and-Investment Balances ....................................13

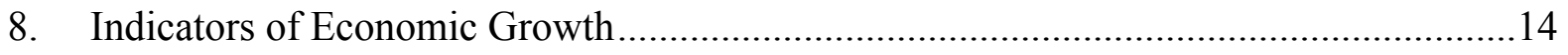

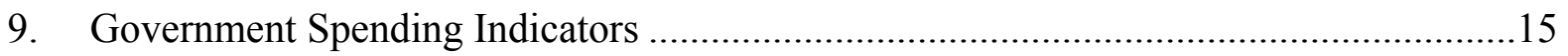




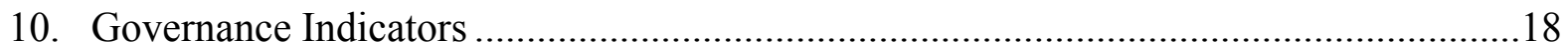

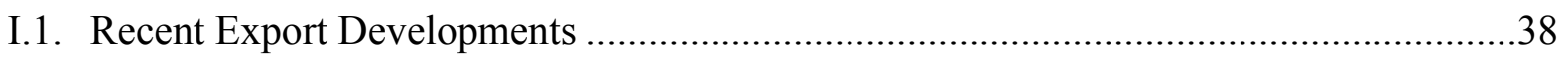

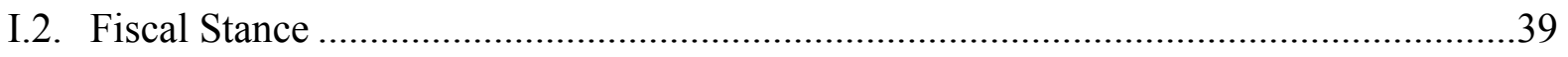

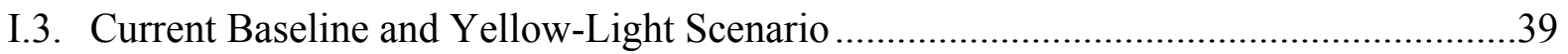

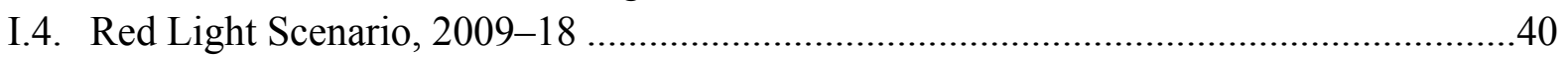

I.5. Indicators of Public External Debt Under Alternative Scenarios, 2005-25 ……............43

Boxes

1. Determining a Sustainable Current Account Deficit ........................................................13

Tables

1. Selected Economic and Financial Indicators, 2004-12 …….....................................28

2. Consolidated Operations of the Central Government, 2004-12 ...................................29

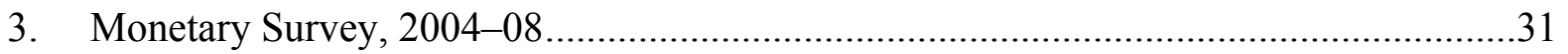

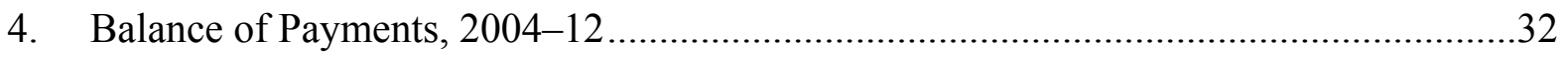

5. IMF Credit Position and Projected Payments to the IMF, 2005-15 ................................33

6. Schedule of Disbursements Under the PRGF Arrangement, 2007-10.............................34

7. Poverty-Reducing Expenditures, 2001-07 …………....................................................

8. Selected Indicators on the Millennium Development Goals, 1990-2005 ……...............36

Appendices

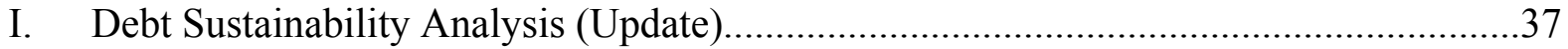

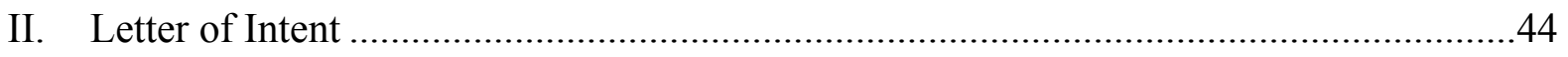

Attachment I. Memorandum of Financial and Economic Policies ............................46

Attachment II. Technical Memorandum of Understanding .......................................57

Appendix Tables

I.1 External Debt Sustainability Framework Including Impact of MDRI,

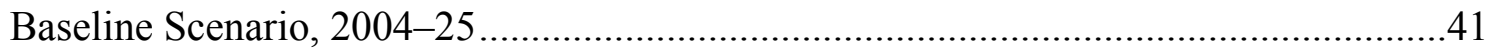

I.1 Sensitivity Analysis for Key Indicators of Public External Debt, 2005-25 ……............42 


\section{LIST OF ACRONYMS}

\begin{tabular}{|c|c|}
\hline $\mathrm{AGO}$ & Auditor General Office \\
\hline BCEAO & Central Bank of West African States \\
\hline CPI & Corruption Perception Index \\
\hline CPIA & Country Policy and Institutional Assessment \\
\hline DDU & Document en Douane Unique (Unique Customs Document) \\
\hline DSA & Debt Sustainability Analysis \\
\hline ECOWAS & Economic Community of West African States \\
\hline ERER & Equilibrium Real Exchange Rate \\
\hline DTIS & Diagnostic Trade Integration Study \\
\hline EPA & Ex Post Assessment \\
\hline HACLCC & $\begin{array}{l}\text { Haute Autorité de Coordination de la Lutte Contre la Corruption } \\
\text { (Supreme Anti-Corruption Authority) }\end{array}$ \\
\hline HIPC & Highly Indebted Poor Country \\
\hline LIC & Low-Income Country \\
\hline LTO & Large Taxpayer Office \\
\hline MDGs & Millennium Development Goals \\
\hline MCC & Millennium Challenge Corporation \\
\hline MDRI & Multilateral Debt Relief Initiative \\
\hline MEFP & Memorandum of Economic and Financial Policies \\
\hline MTEF & Medium-Term Expenditure Framework \\
\hline MTO & Medium Taxpayer Office \\
\hline NPV & Net Present Value \\
\hline OHADA & $\begin{array}{l}\text { Organisation pour l'Harmonisation en Afrique du Droit des Affaires } \\
\text { (Organization for the Harmonization of Business Law in Africa) }\end{array}$ \\
\hline $\mathrm{PC}$ & Performance Criterion \\
\hline PEFA & Public Expenditure and Financial Accountability \\
\hline PFM & Public Financial Management \\
\hline PRGF & Poverty Reduction and Growth Facility \\
\hline PRS & Poverty Reduction Strategy \\
\hline PSI & Policy Support Instrument \\
\hline RER & Real Exchange Rate \\
\hline SIP & Selected Issues Paper \\
\hline SRFP & $\begin{array}{l}\text { Stratégie de Renforcement des Finances Publiques } \\
\text { (Public Finance Strengthening Strategy) }\end{array}$ \\
\hline UNDP & United Nations Development Program \\
\hline TA & Technical Assistance \\
\hline TMU & Technical Memorandum of Understanding \\
\hline VAT & Value Added Tax \\
\hline WAEMU & West African Economic and Monetary Union \\
\hline
\end{tabular}




\section{EXECUTIVE SUMMARY}

- $\quad$ Burkina Faso's recent macroeconomic performance was good. Average real GDP growth was above 6 percent and inflation was low and stable. The fiscal policy stance was in line with policy agreements, but targets for revenue collection were missed.

- $\quad$ Burkina Faso is facing a severe external shock related to the balance of payments implications of weather-related declines in cotton exports and increased oil prices. This is expected to reduce growth, and has negatively impacted the debt sustainability outlook. While policies are being put in place to deal with this shock, the authorities are requesting an increase in access under the PRGF arrangement of 15 percent of quota (SDR 9.03 million). Upon completion of this review, a disbursement of SDR 3.51 million will be available.

- There were delays in structural policy implementation (two structural performance criteria and two benchmarks were missed), although the substance of measures was often in place. The adoption of a pricing mechanism for cotton was a major achievement.

\section{Key Issues}

- Increasing domestic revenues is essential to create fiscal space for poverty-reducing expenditures while keeping debt sustainable. This requires firm efforts to modernize revenue administration and reform the tax regime by broadening the tax base.

- $\quad$ There is some evidence that the real exchange rate is overvalued. The authorities intend to address this through structural reforms aimed at improving competitiveness.

- Improving the climate for private sector development is necessary to sustain growth. Areas of focus will be the financial sector, public utilities and infrastructure, and corruption.

- $\quad$ Public financial management (PFM) needs to be reformed to ensure that public resources are used efficiently and to strengthen governance. Restoring the viability of the cotton sector requires further reforms through government disengagement from the sector.

- Scaling up of aid would help increase growth and reduce poverty. Grant financing is desirable to keep debt sustainable.

\section{Program Risks}

- $\quad$ Risks mainly relate to the domestic revenue effort, the cotton sector, the external environment, and weather-related vulnerabilities. 


\section{INTRODUCTION}

\section{A. Developments Since the 2005 Article IV Consultations}

\section{Burkina Faso's macroeconomic performance in 2005-06 was better than} projected during the last Article IV consultation. Despite a difficult external environment, the economy grew strongly (Text Table 1), compared both to projections and the average for the West African Economic and Monetary Union (WAEMU). In 2006, inflation fell below the WAEMU convergence criterion of 3 percent. The current account improved as official current transfers exceeded expectations. Fiscal policy loosened as planned, with the fiscal deficit (excluding grants) rising. The overall positive macroeconomic performance reflects sound policy implementation, but also delayed adjustment to world cotton prices and additional debt relief. The authorities' policy to pass-through higher energy prices through automatic fuel price adjustments and a tariff increase for electricity were critical for adjusting to the oil price shock. Debt sustainability benefited from MDRI relief, which eased a key constraint on fiscal policy. The revenue effort remained low, including in comparison to other WAEMU countries; with lower-than-projected revenues, the authorities also had to cut back expenditure increases.

Text Table 1. Burkina Faso: Developments Since 2005 Article IV Consultations

\begin{tabular}{|c|c|c|c|c|c|c|c|}
\hline & \multirow{2}{*}{$\frac{2004}{\text { Est. }}$} & \multicolumn{3}{|c|}{2005} & \multicolumn{3}{|c|}{2006} \\
\hline & & Article IV $^{1}$ & Est. & WAEMU & Article IV ${ }^{1}$ & Est. & WAEMU \\
\hline & & \multicolumn{6}{|c|}{ (Annual percentage change) } \\
\hline GDP at constant prices & 4.6 & 3.5 & 7.1 & 4.4 & 4.8 & 5.5 & 3.9 \\
\hline Consumer prices (annual average) & -0.4 & 4.0 & 6.4 & 4.9 & 2.0 & 2.4 & 2.3 \\
\hline Broad money (M2) & -7.2 & 5.3 & -3.8 & 7.2 & 7.1 & 10.2 & 6.1 \\
\hline Credit to the private sector & 12.0 & 4.5 & 24.4 & 15.3 & 3.1 & 14.1 & 11.9 \\
\hline Exports (f.o.b.; valued in CFA francs) & 36.3 & 1.4 & -2.4 & 5.3 & 8.5 & 26.1 & 15.9 \\
\hline Imports (f.o.b.; valued in CFA francs) & 22.1 & 13.1 & 8.6 & 13.6 & 10.6 & 8.5 & 14.2 \\
\hline \multirow[t]{2}{*}{ Terms of trade } & 11.0 & -26.4 & -23.9 & -8.8 & 0.3 & 3.7 & 2.8 \\
\hline & & \multicolumn{6}{|c|}{ (Period average, percent of GDP) } \\
\hline Tax revenue & 11.8 & 12.3 & 11.4 & 14.7 & 13.0 & 11.3 & 15.1 \\
\hline Expenditure and net lending & 21.4 & 22.9 & 21.7 & 21.3 & 24.7 & 22.9 & 22.7 \\
\hline Overall fiscal balance, excluding grants & -8.6 & -9.6 & -9.4 & -5.0 & -10.7 & -10.7 & -5.5 \\
\hline Overall fiscal balance, including grants ${ }^{2}$ & -4.3 & -4.3 & -4.9 & -2.5 & -7.3 & -5.1 & -2.4 \\
\hline Current account balance (excluding current official transfers) & -13.4 & -12.3 & -14.6 & -6.8 & -12.8 & -12.5 & -7.0 \\
\hline Current account balance (including current official transfers) & -10.4 & -9.1 & -11.4 & -5.4 & -11.1 & -9.6 & -5.2 \\
\hline External debt to official creditors & 41.2 & 34.8 & 37.6 & 53.8 & 37.3 & 19.9 & 39.8 \\
\hline
\end{tabular}

Sources: Burkinabè authorities; and IMF staff estimates.

${ }^{1} 2005$ Article IV consultation report (see IMF Country Report No. 05/354, September 30, 2005).

${ }^{2}$ Excluding MDRI grants 
2. The growth performance reflects strong fundamentals, but also limited pass-through of lower world cotton prices to producers (Figure 1). Domestic producer prices have diverged from world cotton prices since the 2002/03 campaign, when world cotton prices peaked in euro terms. Producer prices consistent with profitable ginning operations are, however, expected for the current 2007/08 campaign, for which a new price mechanism was adopted that links domestic producer

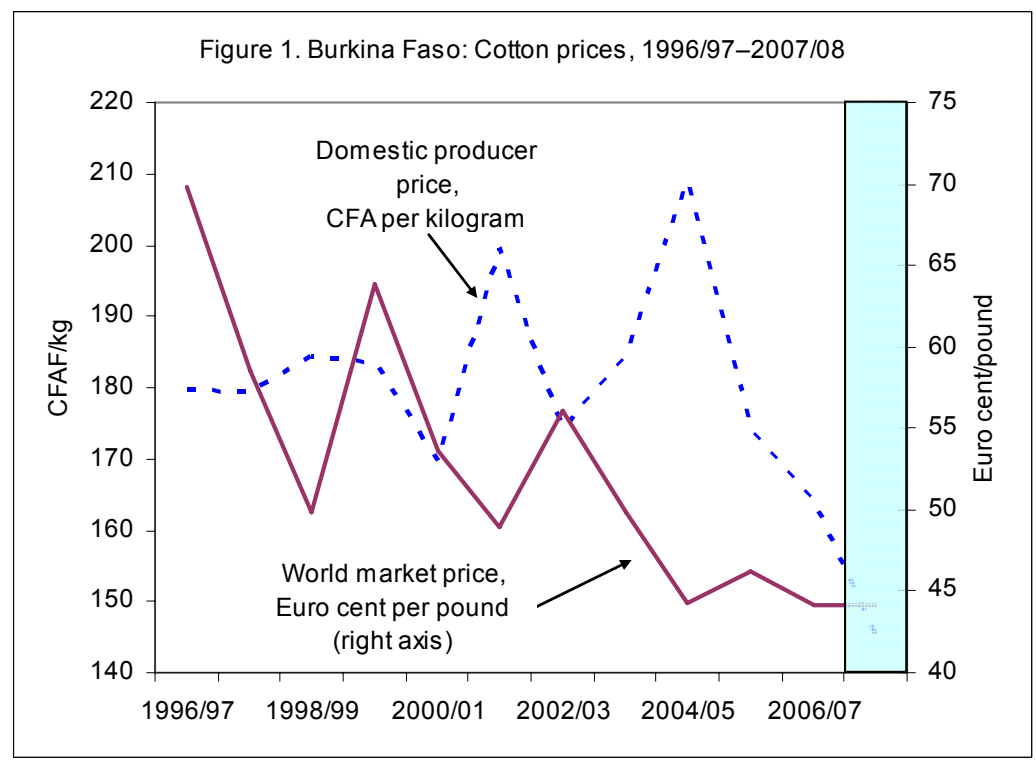
prices to world prices. In the past, limited pass-through shielded producers from the decline in world prices, keeping production — as well as exports and real GDP growth — high. The result was large financial losses at ginning companies, which had to be recapitalized at great cost to the budget.

\section{B. Recent Economic Developments and Outlook}

\section{Cotton production in $\mathbf{2 0 0 7}$ is likely to fall short by almost $\mathbf{5 0}$ percent in} volume terms relative to the original program primarily because of late rainfalls. A lower production base in 2006 (about 15 percent less than expected) and lower cotton producer prices also contributed. As weather conditions normalize, production is projected to rebound in 2008 , but will likely be about 30 percent below the program forecast.

\section{Real GDP growth is forecast at about $\mathbf{4}^{1} \frac{1}{2}$ percent for 2007 and 2008}

(Figure 2), much lower than the $6 \frac{1}{2}$ percent seen in recent years, mainly because of lower cotton production and the recent increase in oil prices. The stimulus from a looser fiscal stance will only partly offset these developments. Inflation has been negative in much of 2007, mostly because food prices have fallen, and is expected to be slightly negative for the year as a whole. The current account deficit, excluding official transfers, will likely widen in 2007 and 2008 because of lower cotton production and higher oil prices, though an expected increase in gold production could partly offset these effects (Figure 3). Moreover, higher grant inflows, including disbursements from the US Millennium Challenge Corporation (MCC), should help rein in the current account deficit, including transfers. 
Figure 2. Burkina Faso: Real Sector Indicators

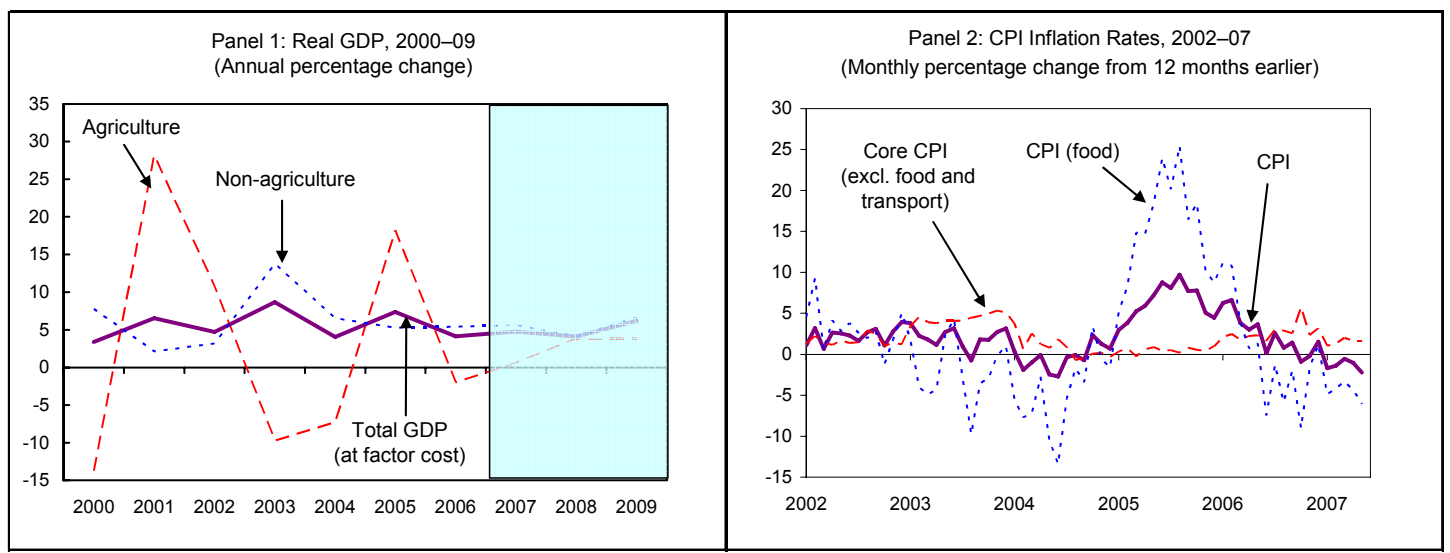

Sources: Burkinabè authorities; and IMF staff estimates.

Figure 3. Burkina Faso: External Indicators

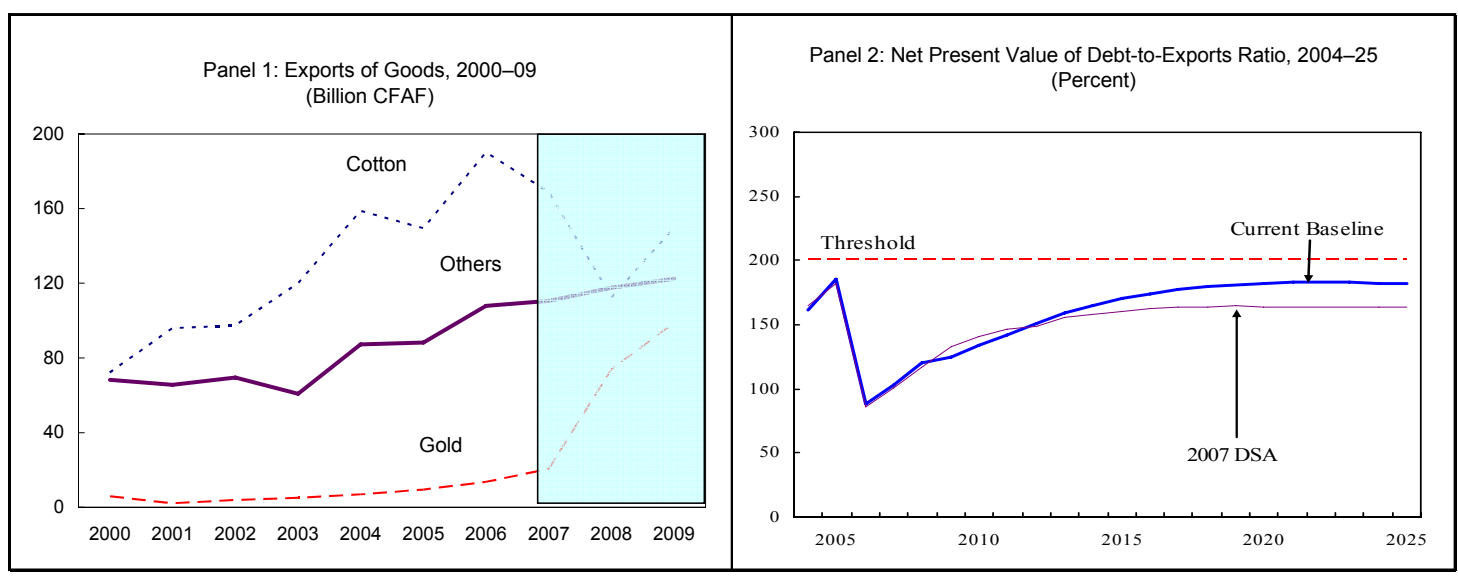

Sources: Burkinabè authorities; and IMF staff estimates.

5. Burkina Faso's risk of debt distress has increased. A key factor is the deterioration in exports. Although Burkina Faso's net present value (NPV) of debt-toGDP ratio is in line with the regional average, its export-based ratios are almost twice the averages (Text Table 2). With exports revised downward because of lower cotton production, even with additional grants, the NPV of debt to exports is projected to rise close to its indicative threshold in the Fund/World Bank Debt Sustainability Analysis (DSA, Figure 3). Another uncertainty is whether Burkina Faso can regain its rating as strong performer under the World Bank's Country Performance and Institutional Assessment (CPIA), following its classification as a medium performer in the 2007 exercise (see DSA appendix). Thus, a reclassification of the debt distress risk as high in the next joint DSA is possible. 
Text Table 2. Post-MDRI Debt Indicators for Burkina Faso and WAEMU Countries, 2007-27 ${ }^{1}$

\begin{tabular}{lcccc}
\hline & \multicolumn{3}{c}{ Peak ratios } & Risk of debt distress rating \\
\cline { 2 - 4 } & $\begin{array}{c}\text { NPV of debt-to- } \\
\text { GDP }\end{array}$ & $\begin{array}{c}\text { NPV of debt-to- } \\
\text { exports }\end{array}$ & $\begin{array}{c}\text { Debt service-to- } \\
\text { exports }\end{array}$ & Moderate \\
\hline Burkina Faso & 22 & 184 & 11 & Moderate \\
Benin & 15 & 99 & 5 & Low \\
Mali & 27 & 106 & 5 & Moderate \\
Niger & 23 & 116 & 5 & Low \\
Senegal & 21 & 86 & 6 & In distress (pre-MDRI) \\
Togo & 21 & 47 & 5 & \\
Average excluding Burkina Faso & 21 & 91 & 5 & \\
\hline
\end{tabular}

Sources: IMF staff reports; and estimates.

${ }^{1}$ Post-MDRI estimates for Côte d'Ivoire and Guinea Bissau were not available.

\section{Surveillance Priorities}

\section{A. External Competitiveness}

\section{Several indicators suggest that Burkina Faso' real exchange rate (RER) is} overvalued. These include competitive pressures in the cotton sector; sluggish noncotton export performance; some estimates of the RER (although the results are not unambiguous; and large and persistent current account deficits. Recent losses in the cotton sector, which stem partly from the appreciation of the euro and the projected decline in exports, are signs the RER is overvalued. In addition, other exports have not yet gained much prominence. ${ }^{1}$ According to an econometric analysis of the equilibrium real exchange rate (ERER), Burkina Faso recently lost competitiveness, though it is unclear from the analysis whether the RER is overvalued. Lastly, Burkina Faso's large current account deficits in recent years could prove unsustainable. The authorities shared some staff concerns about overvaluation, but expected the policies they are adopting to address most competitiveness concerns over time. While there are indications of a real overvaluation, Burkina Faso's membership in the WAEMUwhose RER was deemed in line with fundamentals at the last Article IV consultationgives it ready access to foreign exchange. Moreover, Burkina Faso's fiscal policies have generally been sound.

\section{The euro's appreciation has added to the financial difficulties of the cotton} sector and weighed on export performance. A sharp decline in world cotton prices

\footnotetext{
${ }^{1}$ The evolution of exports as a share of world exports is an alternative measure for assessing external imbalances. In Burkina Faso, this ratio has been relatively stable over the past 10 years; however, this might not be a reliable indicator because cotton production was shielded from the movements in the RER.
} 
(U.S. dollars) since their last peak in late 2003 triggered the sector's crisis (Figure 4). Since then, although U.S. dollar cotton prices have recovered to near historical average levels, the euro has appreciated sharply against the U.S. dollar (Figure 4), effectively offsetting the recovery of world cotton prices. The start-up of large gold mining operations, supported by high gold prices, should partially offset the loss in cotton exports, but cotton remains the economy's most important export. The strength of the euro complicates efforts to diversify into other agricultural products and thus broaden the export base.

Figure 4. Burkina Faso: World Cotton Prices and Euro/Dollar Exchange Rate

Panel 1: World Cotton Prices in U.S. Dollar and Euro, 2001-07 (cent/pound)

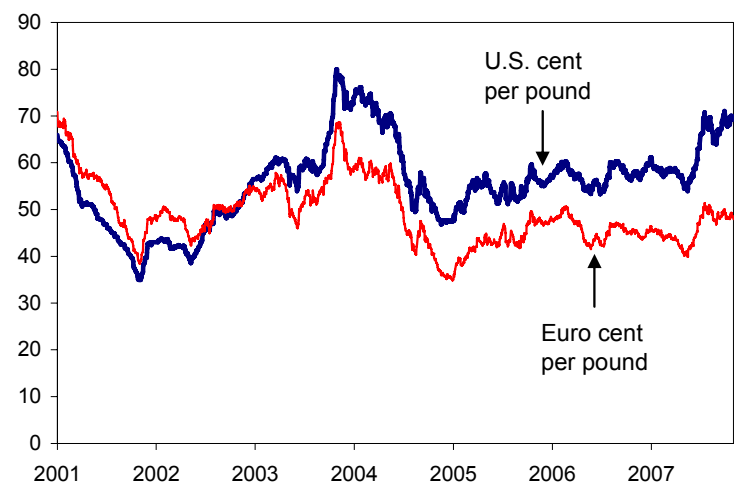

Panel 2: Cumulative Change in the U.S.\$/euro Exchange Rate Since January 2001 (percent)

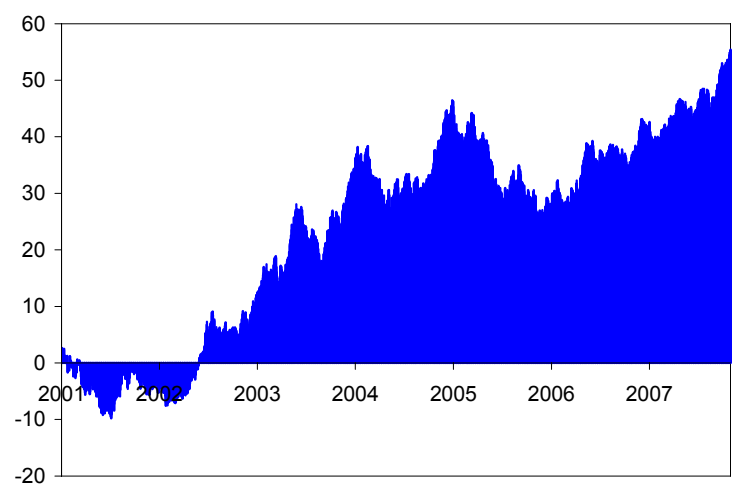

8. Econometric analysis of Burkina Faso's RER produces no clear-cut evidence of overvaluation, but suggests some loss of competitiveness. As of August, 2007, the RER has appreciated by 30 percent since the 1994 devaluation, although it is still 30 percent lower than before it. Staff calculations using cointegration methods suggest that the RER was broadly in line with its fundamentals in 2006 (Figure 5). Two other studies yield contradictory evidence: one finds undervaluation and the other overvaluation. ${ }^{2}$ Despite these diverging results, there is broad agreement that the recent deterioration in the terms of trade would have tended to depreciate the ERER, while the actual real exchange rate appreciated, leading to a loss of competitiveness. However, given the difficulties in determining the ERER, there is considerable uncertainty about whether this has led to an overvaluation of the RER, because this depends on the level of the ERER rate prior to the terms of trade shock. Model uncertainty, data quality issues and the short sample period also complicate the analysis.

\footnotetext{
2 These issues are discussed in more detail in an accompanying selected issues paper (SIP).
} 
Figure 5. Burkina Faso: Indicators of Real Exchange Rate Competitiveness

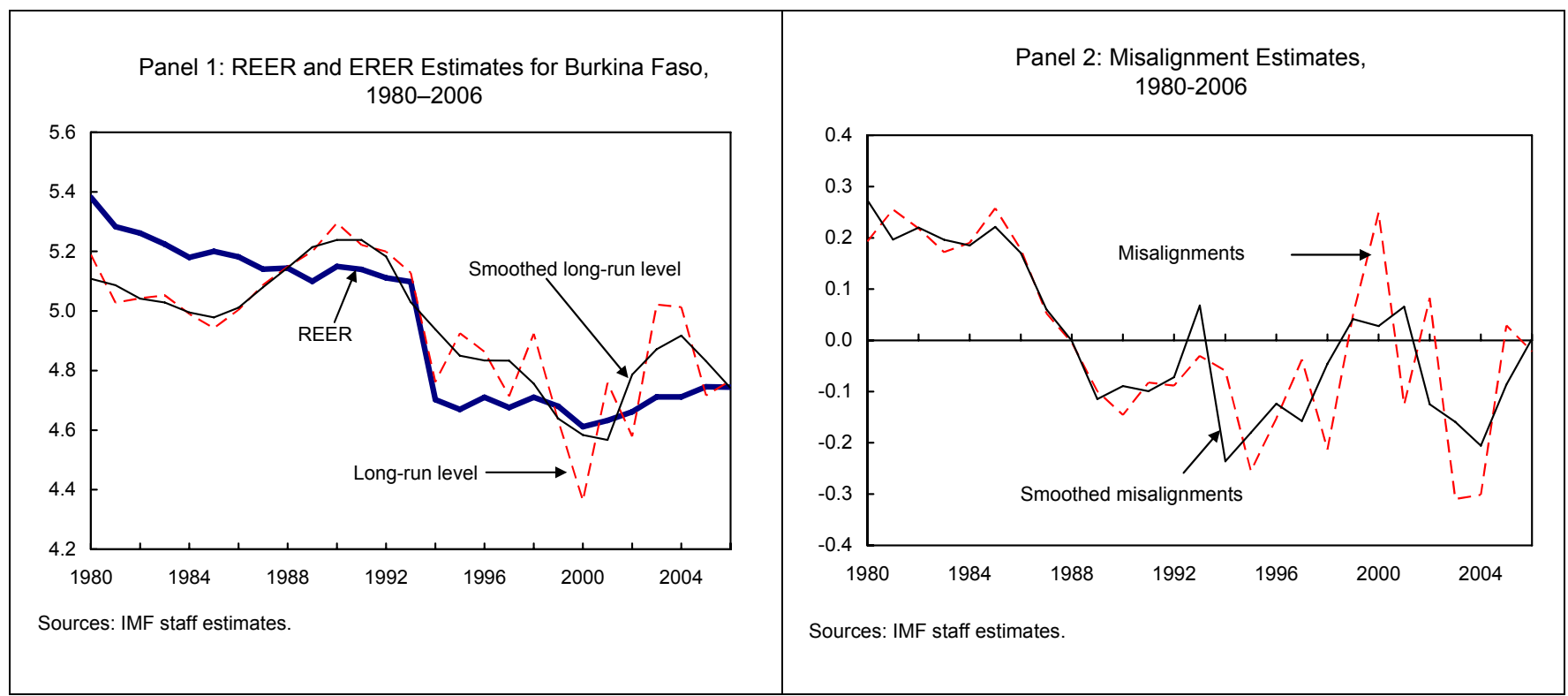

9. The large current account deficit could point to an external imbalance, although the evidence is not conclusive. The current account deficit, including official transfers, averaged 10 percent of GDP in 2002-06, which is large in absolute and relative terms. ${ }^{3}$ If such a deficit were maintained for many years and financed entirely through borrowing, the NPV of debt-to-exports ratio would be unsustainable (Figure 6). ${ }^{4}$ However, only part of the current account deficit over the past five years was financed through borrowing and projected borrowing is unlikely to pose a clear threat to debt sustainability under the baseline (Text Table 3). Under more conservative assumptions for the availability of private sector inflows than in the baseline (Box 1), however, net borrowing of 51/2 percent of GDP would be required. This would be too high to stabilize the NPV of debt-to-exports ratio below its indicative threshold.

\footnotetext{
${ }^{3}$ A multi-year average of the current account deficit was used to filter out the effect of temporary fluctuations. Simulations of the hypothetical current account in the absence of the cotton price shock also suggest an underlying deficit of about 10 percent of GDP.

${ }^{4}$ The focus here is on public borrowing, because it is unlikely that the private sector, with the exception of cotton, has access to external financing, and external public debt sustainability is the main constraint for Burkina Faso.
} 
Figure 6. Burkina Faso: Current Account Balances and Debt-to-Export Ratios

Panel 1: Current Account Balance (Including grants), 1990-2006 (Percent of GDP)

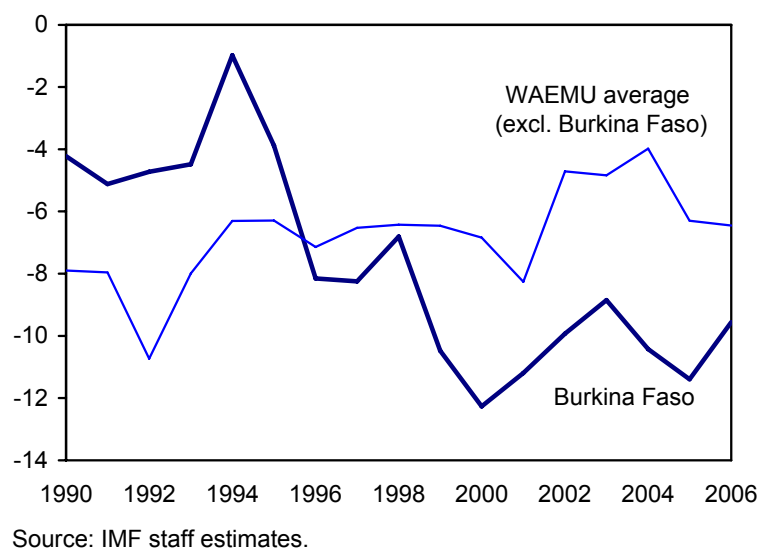

Panel 2: NPV of Debt-to-Exports Ratio for Different Net Borrowing Requirements, 2005-25

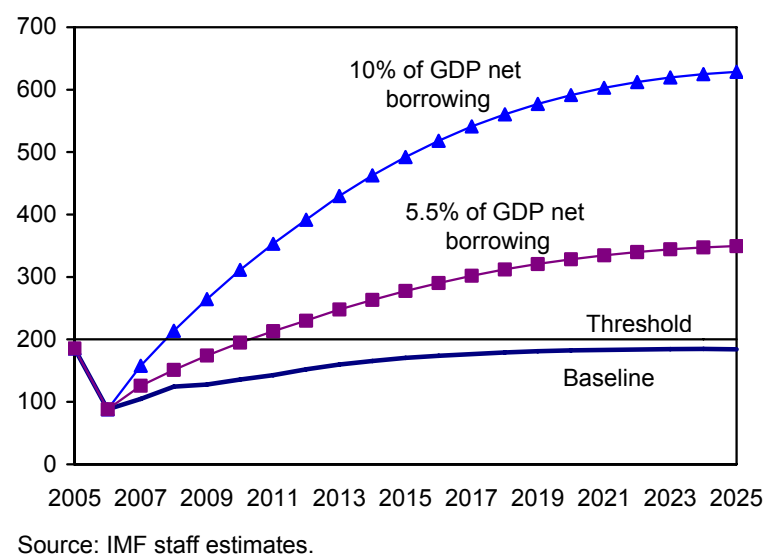

Text Table 3. Burkina Faso: Financing Sources for the Current Account Deficit (In Percent of GDP)

\begin{tabular}{lcr}
\hline & Average 2002-06 & Baseline 2007-25 \\
\hline Current account balance & -10.0 & -9.1 \\
Other non-debt creating inflows, of which: & 6.5 & 6.0 \\
Project grants & 2.9 & 2.9 \\
Private and other nonpublic-debt capital inflows & 4.4 & 3.5 \\
Change in NFA (- represents increase) & -0.8 & -0.5 \\
Net borrowing requirements & 3.4 & 3.1 \\
\hline
\end{tabular}

Sources: Burkinabè authorities; and IMF staff estimates.

${ }^{1}$ Includes errors and omissions.

10. The baseline consolidation of the current account deficit mostly stems from public sector efforts. In the past five years, the public sector savings-and-investment imbalance accounted for about a third of the total current account deficit (Figure 7). Going forward, a stronger revenue effort should boost government savings, reducing the public sector savings and investment gap to almost balance. The gap in private sector savings and investment, on the other hand, is not expected to narrow much, because efforts to improve the business environment and promote private-sector-led growth will likely raise private sector investment. 


\section{Box 1. Determining a Sustainable Current Account Deficit}

Another way to assess the sustainability of the current account outlook is to determine its net borrowing implications. Debt-financing of the current account deficit directly impacts the debt sustainability outlook. However, sustainable non-debt-financing inflows appear significant in Burkina Faso. In 2002-06, for example, the average current account deficit of 10 percent of GDP was mostly financed by non-debt inflows, in particular project grants, private sector inflows, and errors and omissions (Text Table 2).

Looking forward, these non-debt-financing inflows are key to evaluating a sustainable current account position. Project grants could be about 3 percent of GDP, in line with experience and donor intentions. Furthermore, a build-up of net foreign assets (NFA) of about $1 / 2$ percent of GDP per year would be consistent with maintaining the reserve cover at about $3 \frac{1}{2}$ months of imports. The largest uncertainty regards the level of private inflows: Over the past five years, these averaged about $4 \frac{1}{2}$ percent of GDP but included approximately $2 \frac{1}{2}$ percent in errors and omissions that are not necessarily sustainable. A conservative estimate for sustainable private inflows might therefore be 2 percent of GDP. This is lower than in the baseline, which assumes that progress in improving the business environment boosts foreign investment inflows. Thus, non-debt-financing inflows of about $4 \frac{1}{2}$ percent of GDP could be considered sustainable - project grants ( 3 percent of GDP) plus private sector inflows ( 2 percent of GDP) minus a buildup of NFA $(1 / 2$ percent of GDP).

With such an estimate for non-debt-financing inflows, a current account deficit of 10 percent of GDP would not be sustainable because it implies net borrowing requirements of $5 \frac{1}{2}$ percent of GDP, which would lead to steadily increasing debt ratios (Figure 7). To keep the NPV of debt-toexports ratio below its indicative threshold, net borrowing requirements should not exceed 3 percent of GDP, in line with borrowing plans under the baseline. Consequently, with 41/2 percent of GDP in sustainable non-debt- financing inflows, a sustainable current account deficit would be about $7 \frac{1}{2}$ percent of GDP.

Figure 7. Burkina Faso: Baseline Current Account and Savings-and-Investment Balances

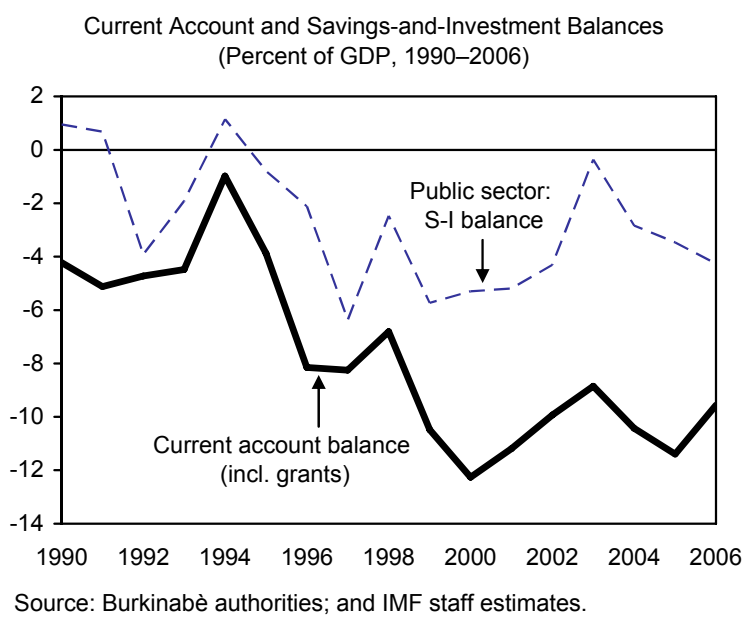

Current Account and Savings-and-Investment Balances (Percent of GDP, 2006-25)

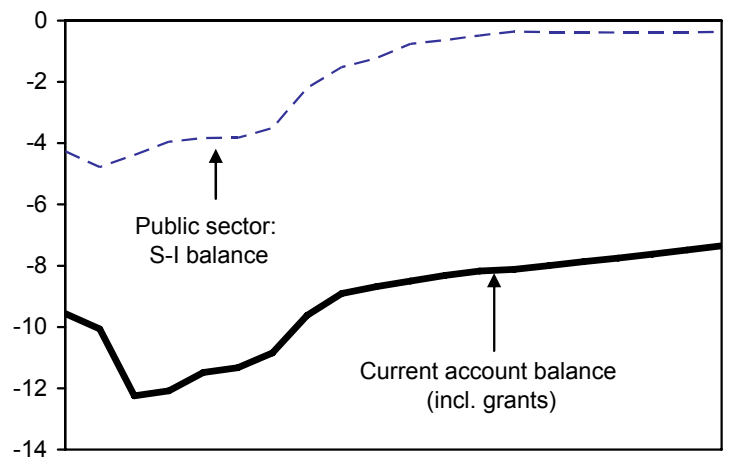

2006200820102012201420162018202020222024 Source: Burkinabè authorities; and IMF staff estimates. 


\section{If the strong private sector capital inflows assumed in the baseline do not} materialize, further public or private sector adjustment might be needed to sustain the current account deficit. The NPV of debt to exports ratio could be brought below its indicative threshold by tightening fiscal policy. Alternatively, private sector adjustment, spurred through a real depreciation in the exchange rate, could help reduce the current account deficit. The real depreciation, however, would likely need to be relatively large since Burkina Faso's openness to trade is low and its dependence on commodity exports high, implying the trade balance is likely to change little with movements in the RER.

\section{B. Growth Prospects}

12. Economic growth in the past $\mathbf{1 0}$ years was strong. Burkina Faso saw growth accelerate in the mid-1990s, which broadly carried over into recent years (Figure 8). The large devaluation of the CFA franc is likely to have contributed to the growth acceleration by boosting cotton production and exports (Figure 8)-consistent with results from the empirical growth literature. Growth outside the cotton sector (which accounts for 5 percent of GDP but drives other activities) was broad based, supported in particular by the telecommunications and transportation sectors. This broad base bodes well for future growth prospects, although the euro's recent appreciation will make it harder for Burkina Faso to expand its exports base.

Figure 8. Burkina Faso: Indicators of Economic Growth

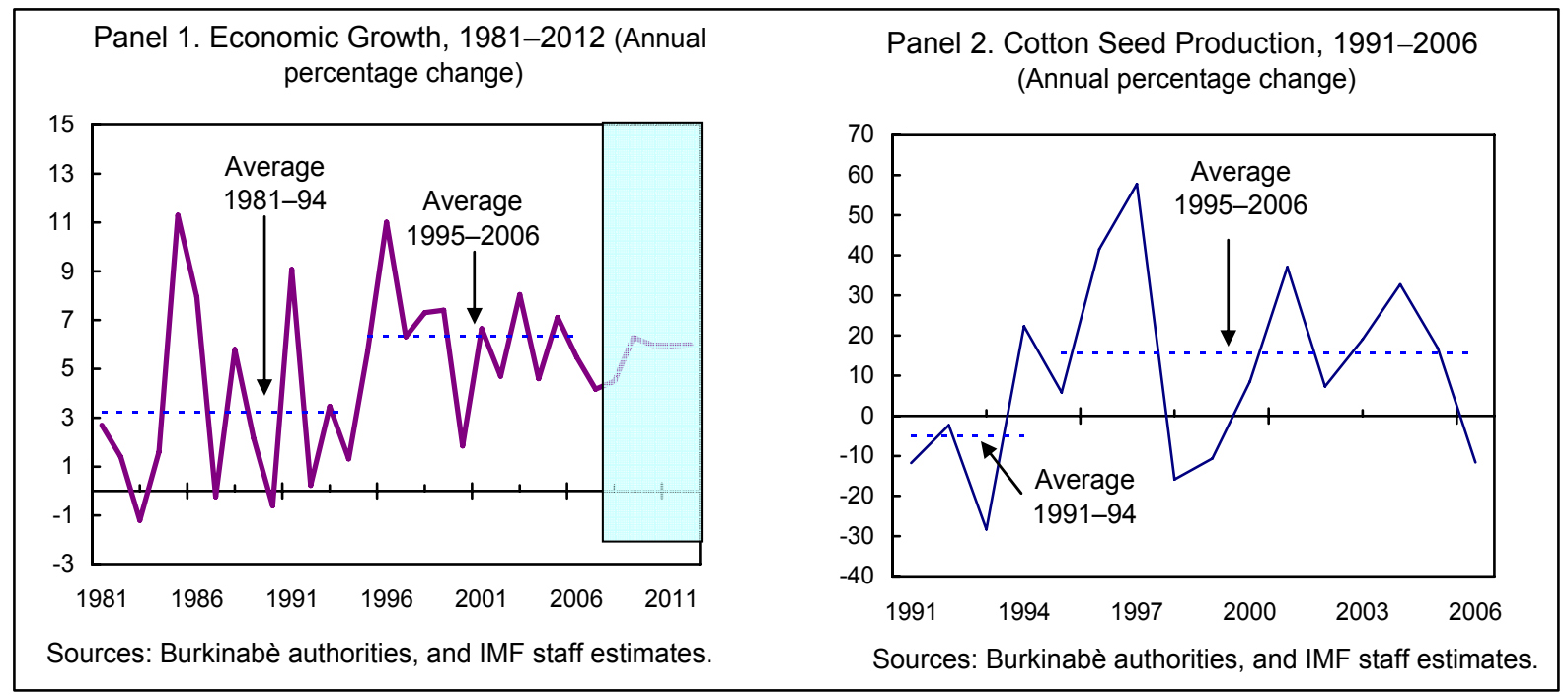

13. Increased public investment should bolster the foundation for growth. The authorities intend to raise public investment spending by about $2 \frac{1}{2}$ percent of GDP over 2007-10 from its average in the preceding five years (Figure 9). For 2007, this includes approximately 1 percent of GDP for the recapitalization of SOFITEX, whereas for 2008 and beyond the bulk of the additional resources is intended for 
infrastructure projects. ${ }^{5}$ Grants from the U.S. MCC, about 1 percent of GDP over 2008-10, are expected to finance a substantial part of these additional expenditures. As suggested in the empirical literature, a 1 percentage point increase in the public investment-to-GDP ratio could increase the per capita GDP growth rate by about 0.2 percentage points; consequently, the envisioned increase in public investment spending should contribute about $1 / 2$ percentage points to medium-term GDP growth, as reflected in the baseline. ${ }^{6}$ While grant inflows create some fiscal space, further efforts, in particular a higher revenue effort, will be needed to make such expenditure levels sustainable over the medium term.

Figure 9. Burkina Faso: Government Spending Indicators
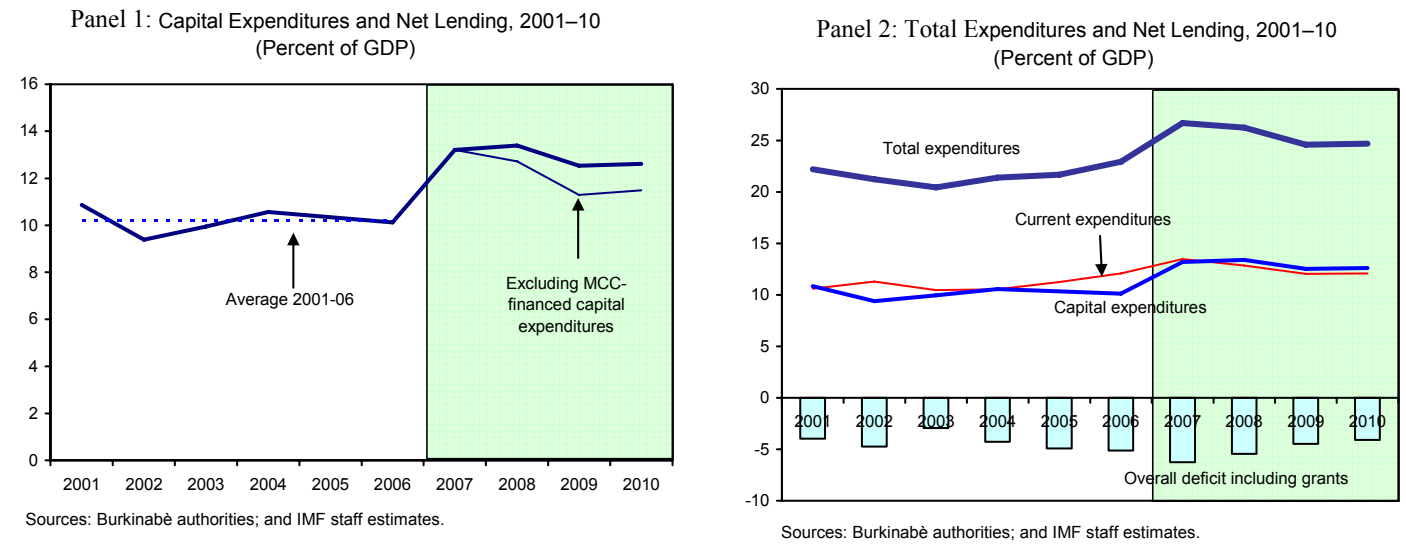

\section{Stronger growth will also require structural reforms to improve the} investment climate. The most problematic factors for doing business according to recent surveys are (i) access and cost of finance; (ii) tax regulations and tax rates; (iii) corruption; and (iv) an inefficient government bureaucracy. ${ }^{7}$ A number of initiatives are underway to address these issues; for example, the regional Financial Stability Assessment Program (FSAP) conducted in late 2007, as well as a Burkina Faso-specific FSAP planned for spring 2008, will assess financial sector access constraints. Likewise, work under the program to improve tax administration and streamline the tax code (see below) should ease the administrative burden on taxpayers and will likely reduce tax rates in return for a broader tax base. Regarding corruption, perceptions appear to have worsened recently, and forceful action by the

\footnotetext{
${ }^{5}$ Projects include improving cross-border connections, rural road building, and rural electrification programs.

${ }^{6}$ The accompanying selected issues paper provides a deeper discussion of public investment and growth.

${ }^{7}$ See "World Bank Investment Climate Assessment" and the "World Economic Forum Competitiveness" reports.
} 
authorities will be required to stem this trend (see below). Substantial progress has been made in improving the business environment: Burkina Faso is ranked among the five top reformers in Africa in the Doing Business 2008 report. ${ }^{8}$ Nevertheless, its absolute rank in several surveys, while in line with the WAEMU average, is still among the least competitive in the world (Text Table 4).

Text Table 4. Burkina Faso: Indicators of Non-Price Competitiveness

\begin{tabular}{lr|lr}
\hline Ease of doing business & Ranking out of 175 & Global competitiveness index & Ranking out of 128 \\
\hline Overall ranking & 163 & Overall ranking & 119 \\
Dealing with licenses & 168 & Health and primary education & 127 \\
Registering property & 164 & Higher education and training & 119 \\
Trading across borders & 154 & Macroeconomy & 119 \\
Employing workers & 153 & Infrastructure & 113 \\
Enforcing contracts & 143 & Technological readiness \\
Starting a business & 131 & Business sophistication & 106 \\
Paying taxes & 129 & Market efficiency & 101 \\
Getting credits & 117 & Innovation & 89 \\
Protecting investors & 99 & Institutions & 70 \\
Closing a business & 90 & & 67 \\
\hline
\end{tabular}

Sources: World Bank Doing Business 2007 and World Economic Forum Global Competitiveness Index 2007.

\section{Public Sector Efficiency}

15. The planned tax policy reform is aimed at generating further revenue and simplifying and eliminating nuisance taxes. Regarding tax administration, a recent FAD mission noted the need for measures to boost revenue quickly without distracting the administration from medium-term reform priorities. Key measures going forward are (i) full computerization of the large and medium taxpayer offices, especially for monitoring taxpayer obligations, and (ii) simplification of exemptions to make tax administration more productive and lower compliance and administrative costs. The authorities are determined to implement this reform program.

16. The authorities have approved a new public finance strategy and multiyear action plan, which benefited from input from FAD and AFRITAC-West. A review conducted in spring 2007 based on the Public Expenditure and Financial Accountability (PEFA) methodology found that Burkina Faso scores well on the credibility of its budget - with the notable exception of revenue projections being too optimistic - and the comprehensiveness and transparency of the budget. However, the effectiveness of ex-post controls are weak. There is also scope for improving ex-ante

\footnotetext{
${ }^{8}$ Key measures include the introduction of specialized commercial chambers in the general courts; lowering the cost of enforcing a judgment; reducing the cost of property registration to 12.2 percent of the property value; and establishing a one-stop shop for company registration that cut the time for business start-up to 18 days.
} 
controls; a recent FAD PFM mission recommended simplifying expenditure procedures and eliminating redundant controls. The authorities' domestic debt audit, completed in mid-2007 similarly found that such weaknesses led to expenditure commitments outside the budget process and, consequently, payment delays, which are being addressed. ${ }^{9}$

\section{Burkina Faso ranks relatively well on quality of governance and corruption indicators, but there have been some slippages recently. On most} governance indicators - government effectiveness, corruption, voice, and accountability - Burkina Faso ranks above the average of WAEMU, sub-Saharan Africa, and other low-income countries (Figure 10). Year-to-year comparisons are difficult, however, Burkina Faso's rankings on the World Bank's governance indicators have shown little improvement and its score on Transparency International's Corruption Perception Index (CPI) has dropped. ${ }^{10}$ The authorities are aware of these developments, which they attribute partly to misperceptions, and are determined to continue to fight corruption. They intend to redouble efforts by merging three institutions into a state control authority (Autorité Supérieure de Contrôle d'État (ASCE)), which will investigate government agencies and monitor the work of audit offices. In addition, unlike its predecessors, it will have power to take direct legal action and will independently publish its reports. This new institution is an integral part of the authorities' strategy to strengthen public financial management through better ex-post controls.

\footnotetext{
${ }^{9}$ Payments took place only after these commitments were discovered by the debt audit. The delays are not arrears under the program, which follows the WAEMU definition as expenditures approved for payment but not paid within three months.

${ }^{10}$ Burkina Faso's CPI score declined from 3.4 in 2005 to 2.9 in 2007 (a score below 3 suggests a perception of rampant corruption). However, the confidence interval is relatively wide, ranging from 2.6 to 3.4. Within Africa, Burkina Faso ranked 17 out of 52 countries in 2007.
} 
Figure 10. Governance Indicators

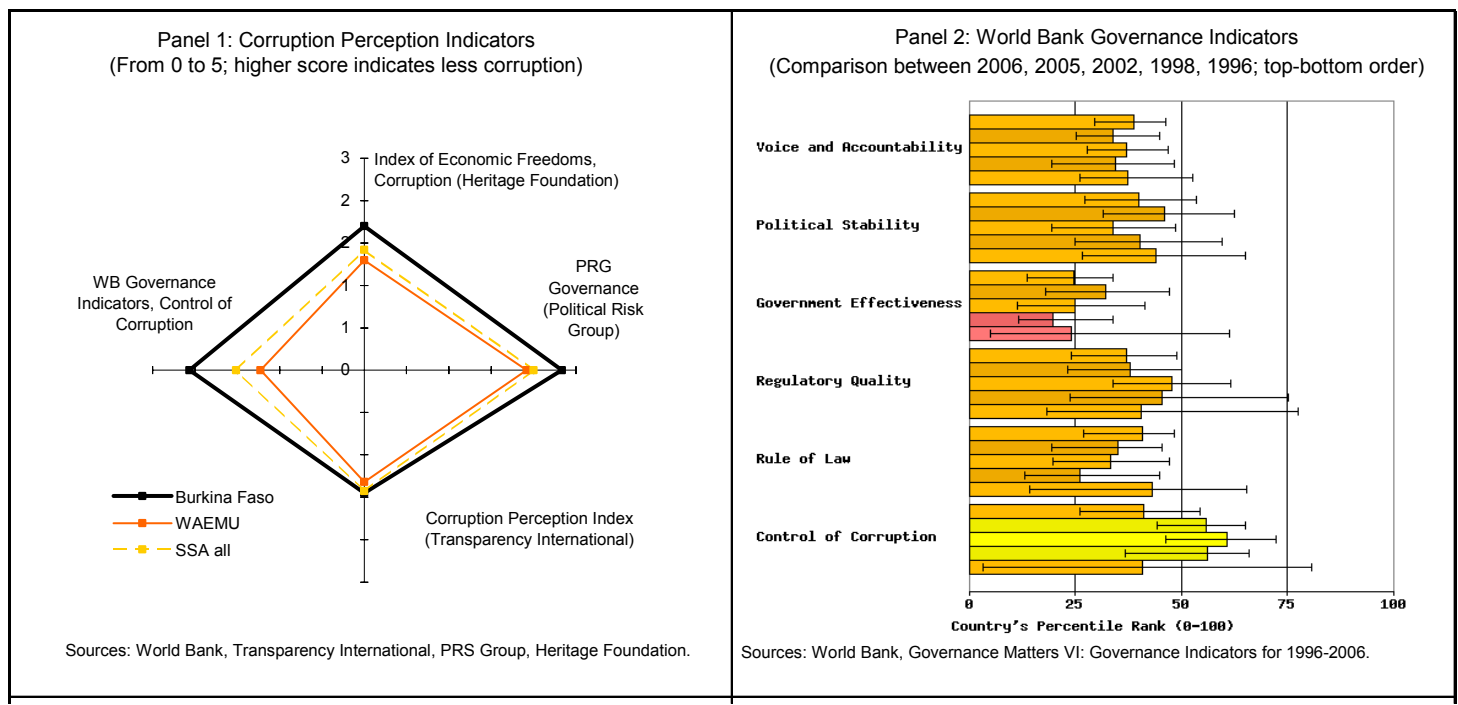

\section{Policy Implications Going Forward}

\section{Enhancing private sector efficiency is a key medium-term challenge to} address real exchange rate overvaluation and bolster growth. Burkina Faso's membership in a currency union implies ample access to foreign exchange to finance its balance-of-payment needs. Nevertheless, addressing the potential overvaluation is critical (i) because it adversely affects the competitiveness of the tradable sector, and (ii) because it contributes to potentially unsustainable large current account deficits. The WAEMU membership rules out a nominal depreciation to reverse the overvaluation, which puts the onus on productivity gains to compensate the loss of competitiveness. This is primarily a challenge for the private sector, but public sector reforms and growth-oriented public investment can contribute by enhancing the investment climate. Given that part of the cotton price shock is likely to be permanent, productivity increases through liberalization in this sector are particularly critical. The authorities also viewed increased productivity as essential for stimulating growth and adjusting to the external shock.

\section{The increased risk to the external public debt sustainability outlook} reinforces the need for medium-term fiscal consolidation, which would contribute to reducing external imbalances. In order to sustain high expenditures under Burkina Faso's poverty reduction strategy, fiscal consolidation will require strong increases in revenue, based on ongoing and envisioned revenue reforms. These reforms will take time to become effective, and thus require a somewhat back-loaded adjustment path. Gains in public sector efficiency will be important as well to create fiscal space for poverty-reducing expenditures without putting pressure on the deficit. The authorities agreed with the need for medium-term fiscal adjustment, but emphasized that it should not come at the expense of reduced growth. 


\section{Program Implementation}

\section{A. Program Implementation and Policies for the Remainder of 2007}

20. While some indicative fiscal targets for June 2007 were narrowly missed, the deficit target was observed. Government revenue at the end of June fell short by less than 0.1 percent of GDP, though grants exceeded projections by 0.3 percent of GDP. On the expenditure side, on a commitment basis, expected payments for goods and services were higher than expected because of one-off expenditures (e.g., resulting from the ongoing decentralization), larger externally financed capital spending, and higher-than-projected expenditure execution rates through June. Poverty-reducing expenditures, though, fell marginally short of the target. The end-June performance criterion on the fiscal deficit, including grants (on a payments-order basis), was met.

21. The deficit target for 2007 should be observed, despite lower projected revenue. Because of lower-than-expected growth and inflation, the nominal revenue year-end target was lowered but is still 1 percentage point of GDP higher than in 2006, exceeding the programmed increase by 0.2 percentage points (Table 2). Grants are now projected to be 2 percent of GDP higher than previously programmed, mainly because grant-financed projects were executed faster than expected and some budget support grants came in. Thus, the year-end target for the deficit, including grants, is projected to be met despite higher expenditure. Most of the additional spending will be on capital projects and moderately higher current expenditure, in particular for utilities and wages. The projections also include allocations to complete SOFITEX's recapitalization and repay VAT refund requests.

22. Some structural reforms in tax and customs administration were delayed, although the substance of measures was often in place. The delays resulted partly from the large reform agenda; for example, beyond initiatives in the program, the authorities developed a comprehensive reform strategy for tax administration. Regarding program performance, the large taxpayer office did not promptly send automatic reminders to all late filers and non-filers starting in July (continuous structural performance criterion). This measure will be implemented starting in February, 2008; the recently appointed new director of computerization will oversee the implementation. The authorities also delayed the payment of VAT refunds (structural benchmark, Text Table 5), but this issue was rectified in November 2007 (MEFP q9). Regarding customs administration, the customs-specific valuation database has been put in place in all computerized offices as planned. The authorities came close to meeting the benchmark for implementing a single customs declaration form by end-June, but one computerized office and small non-computerized offices experienced delays; consequently, the single customs declaration form became 
Text Table 5. Burkina Faso: Structural Conditionality Implementation Status

\begin{tabular}{lll}
\hline Measure & Timing & PC / Implementation \\
& & Benchmark
\end{tabular}

\section{Tax administration}

Use Sintax to generate a list of LTO late filers and nonfilers for the main tax categories (VAT, corporate income, tax on income from securities, and tax on income from real estate), and send reminders within a week after the declaration deadline.

Put in place a mechanism to accelerate VAT refunds so that verified refund requests are paid within 90 days.

\section{Customs administration}

Implement the single customs declaration form.

Make main ASYCUDA modules fully functional in computerized offices and put them into operation, beginning with Ouagadougou.

Put in operation a computerized customs-specific valuation database in the computerized offices.

\section{Public financial management}

Introduce a comprehensive system for tracking foreign-financed expenditures.

\section{Tax policy}

Submit the single tax code to parliament consolidating all tax legislation.

Secure approval from the Council of Ministers for a tax policy reform strategy in line with Fund staff recommendations.

\section{Cotton sector}

Adopt a formula-based producer price mechanism for cotton linking the producer price to world prices in collaboration with the World Bank.

Secure government approval of a liberalization strategy for SOFITEX in collaboration with the World Bank.
June 30, 2007

(start date)

Continuous

PC

Not met; continuous implementation beginning February 1, 2008

June 30, 2007

Benchmark $\left(1^{\text {st }}\right.$ review $)$

Not met; implemented as of November 15, 2007

June 30, 2007

$\mathrm{PC}$
$\left(1^{\text {st }}\right.$ review $)$

Not met; implemented as of November 22, 2007.

September 30, 2007

Benchmark $\left(1^{\text {st }}\right.$ review)

Not met; expected to be met as of December 31 , 2007

September 30, Benchmark Met $2007 \quad\left(1^{\text {st }}\right.$ review $)$

December 31, Benchmark ( $2^{\text {nd }}$ review)

Substantial delays until at least 2009

December 31 2007

Benchmark ( $2^{\text {nd }}$ review)

Expected to be met

December 31, Benchmark $\left(2^{\text {nd }}\right.$ review)

Likely delay; expected to be met by end-April 2008

June 30, 2007

Benchmark (1 ${ }^{\text {st }}$ review)

Met

December 31, Benchmark ( $2^{\text {nd }}$ review)
Expected to be met 
effective in all offices in November 2007 (MEFP $q 10$ ). Finally, the structural benchmark for making the ASYCUDA customs system fully operation in Ouagadougou will be delayed until end-December.

23. Some tax policy and PFM measures envisioned for $\mathbf{2 0 0 7}$ are likely to be delayed. The authorities are on track to submit the single tax code consolidating all tax legislation to parliament by December 2007. However, the required technical work for the tax reform strategy took longer than expected, and approval by the cabinet (structural benchmark for end-December), is likely to be delayed until April 2008. Finally, considerable technical difficulties, in particular regarding software interfaces, have emerged in developing a system for tracking foreign-financed expenditures, now expected to be operational in 2009 (MEFP q20).

24. The cotton sector reform agenda is on track. The producer price mechanism for cotton was adopted in May, meeting a structural benchmark; the authorities are also expected to meet the end-December structural benchmark on the approval of a liberalization strategy for SOFITEX. Regarding the automatic adjustment mechanism for petroleum products, price adjustments slowed after July 2007, but the authorities are committed to fully implementing the automatic price adjustment mechanism in 2008.

\section{B. Economic and Structural Policies for $\mathbf{2 0 0 8}$ and the Medium Term}

\section{Fiscal Program for 2008}

\section{Domestic revenues are projected to decrease as growth slows, but} additional grants and privatization receipts provide greater flexibility:

- $\quad$ Revenue outlook. The fall in cotton production and reduced economic growth will lower tax revenue in nominal terms (Text Table 6); moreover, the authorities intend to lower the corporate income tax in order to increase competitiveness, which will lower revenue by about CFAF 10 billion (0.3 percent of GDP). As a ratio to GDP, revenues are still projected at 13.6 percent of GDP.

- Grants. When Burkina Faso's debt distress risk was reclassified from low to moderate, its financing from the World Bank and African Development Bank became half grants. Some other donors are also expected to increase grantsmost notably, the authorities expect to receive a first grant disbursement from the MCC. Grants are projected at 7.2 percent of GDP in 2008, from 4.7 percent of GDP under the original program.

- $\quad$ Expenditures. The nominal expenditure projections are broadly in line with the original program targets except for greater net lending due to the onlending of a concessional loan by the French Development Agency for the cotton 
smoothing fund (see below) and a loan to the state-owned electricity company for a large capital project.

- Domestic financing. Given the reduction in revenue and slightly higher expenditures, as well as broadly unchanged foreign financing, domestic financing requirements have increased relative to the original program target, but this is mostly covered by privatization receipts expected from the sale of a 20 percent share of ONATEL. ${ }^{11}$

Text Table 6. Burkina Faso: Summary of Government Operations, 2006-08

\begin{tabular}{|c|c|c|c|c|c|c|c|c|c|}
\hline & \multicolumn{2}{|c|}{2007} & \multicolumn{2}{|c|}{2008} & \multirow{2}{*}{$\begin{array}{r}2006 \\
\text { Est. }\end{array}$} & \multicolumn{2}{|c|}{2007} & \multicolumn{2}{|c|}{2008} \\
\hline & Prog. & Proj. & Prog. & Proj. & & Prog. & Proj. & Prog. & Proj. \\
\hline & \multicolumn{4}{|c|}{ (Billions of CFA francs) } & \multicolumn{5}{|c|}{ (Percent of GDP) } \\
\hline Total revenues and grants & 628 & 678 & 683 & 732 & 17.8 & 18.2 & 20.4 & 18.2 & 20.8 \\
\hline Domestic revenues & 450 & 440 & 508 & 478 & 12.3 & 13.1 & 13.3 & 13.6 & 13.6 \\
\hline Grants & 178 & 238 & 175 & 255 & 5.6 & 5.2 & 7.2 & 4.7 & 7.2 \\
\hline Expenditure and net lending & 841 & 885 & 896 & 924 & 22.9 & 24.4 & 26.7 & 23.9 & 26.2 \\
\hline Current expenditure & 419 & 447 & 454 & 452 & 12.1 & 12.2 & 13.5 & 12.1 & 12.9 \\
\hline Capital expenditure and net lending & 422 & 438 & 443 & 472 & 10.9 & 12.2 & 13.2 & 11.8 & 13.4 \\
\hline Overall balance (commitment basis) & -213 & -207 & -213 & -192 & -5.1 & -6.2 & -6.2 & -5.7 & -5.4 \\
\hline Excluding grants & -391 & -445 & -388 & -447 & -10.7 & -11.3 & -13.4 & -10.3 & -12.7 \\
\hline
\end{tabular}

Sources: Burkinabè authorities; and IMF Staff estimates and projections.

\section{The proposed fiscal stance strikes a balance between deficit reduction and} maintaining expenditures in the face of revenue shortfalls. Normally, with increased risk of debt distress, the additional grants related to the debt distress revision (about 1 1/4 percent of GDP) would best go to reducing the fiscal deficit (including grants), which was originally envisioned at 5.7 percent of GDP for 2008. Adjusting for the nominal revenue shortfall would require spending cuts, however, which would exacerbate the negative growth impact and could jeopardize progress towards the Millennium Development Goals. Weighing these considerations, the authorities agreed to use about $1 / 4$ of the additional grants to reduce the 2008 deficit to 5.4 percent of GDP; the remaining grants will help offset the revenue losses and allow for a slight increase in net lending.

\section{Structural Fiscal Agenda}

\section{Tax administration reform in $\mathbf{2 0 0 8}$ will concentrate on consolidating} reforms of the large taxpayer office. For example, the introduction of a systematic notification system for non-filers, combined with issue-oriented taxpayer audits,

11 This sale was originally planned for 2007 . 
should reduce the non-filer rate below 5 percent in 2008, in line with international good practice (MEFP $\$ 17$ ). Likewise, the combination of new procedures for VAT refunds and sufficient budgetary resources should eliminate past delays in VAT refunds. New measures for 2008 for strengthening tax administration include revised regulations to focus the large and medium taxpayer offices on the largest 500 and 1,500 medium taxpayers, respectively, and to subject small taxpayers to simplified taxation instead of the regular value-added tax (structural benchmark for end-June); ${ }^{12}$ and eliminate withholding taxes for large taxpayers.

\section{Customs administration reform in 2008 aims to reduce direct contact} between customs officials and traders. An important aspect is the choice of the appropriate customs channel, which should be selected by ASYCUDA's selectivity module and not by individual customs agents. The authorities have agreed to limit the deviation from ASYCUDA recommendations for the customs channel to less than 10 percent, and they will program the selectivity module to assign at least 50 percent of customs declarations to the green and blue channels, in order to focus customs resources on higher-risk declarations and to reduce the administrative burden on importers (structural benchmark for end-September). Building on the customs-specific valuation database introduced in 2007, the authorities intend to interface it with ASYCUDA and use it for dues calculation and risk assessment in the selectivity module.

\section{The ambitious revenue targets for 2009 and beyond require that a tax} policy reform agenda be approved by parliament in 2008/09. This reform agenda will draw on work done by a FAD tax policy mission to Burkina Faso in November/December 2007. The goal is to broaden the tax base for major taxes, eliminate nuisance taxes, and simplify the tax system. The authorities decided to reduce the corporate income tax rate from 35 percent to 30 percent as part of the 2008 budget to bring it closer to rates in neighboring countries. However, this has shrunk the scope for further reductions in tax rates. Given the time needed to prepare the legislation and the parliamentary timetable, the draft tax reform legislation will be submitted to parliament by end-December 2008 (structural benchmark), and the bulk of the reforms are expected to take effect only in 2010. Key tax policy measures, however, will already be included in the 2009 budget, scheduled to be submitted to parliament in September 2008 (structural benchmark).

30. To improve public financial management, the program in $\mathbf{2 0 0 8}$ will focus on strengthening budget execution, ex post controls, and expenditure tracking. To find ways to shorten the payment process, the authorities will review existing ex-ante controls and the scope for reducing redundancies and plan to develop an action plan by end-December 2008 (MEFP $\mid 19$, structural benchmark). Streamlining and enhancing

\footnotetext{
${ }^{12}$ Turnover would be used as the sole criterion for classifying the taxpayer population, and small taxpayers would no longer be subject to VAT.
} 
the effectiveness of these controls would improve budget execution and address weaknesses identified by a recent FAD PFM mission. Moreover, the authorities' audit of domestic debt obligations has shown that stronger ex-ante controls are needed to ensure that line ministries do not enter into expenditure commitments outside the budget process. The new institution for control and oversight (ASCE), will help reinforce ex-post controls; the authorities plan to develop an action plan for scaled-up audit activities, ensure sufficient funding in the 2009 budget, and develop modalities for publication of audit reports and systematic follow up. A comprehensive system for tracking poverty-reducing expenditures is expected to be introduced by end-June 2008 (structural benchmark). ${ }^{13}$

\section{Cotton Sector}

31. The authorities are working with stakeholders to restore the financial viability of the cotton sector. Because of the limited pass-through of lower world cotton prices to producers, ginning companies have had sizable financial losses. To help ensure the viability of the ginning companies, a new mechanism for the 2007/08 campaign links the producer floor price to world cotton prices (centered five-year moving average), discounted by 5.1 percent. This brought the producer floor price down to CFAF 145 per $\mathrm{kg}$ for 2007/08, from CFAF 165 per $\mathrm{kg}$ for 2006/07. If current price levels prevail over the next few months, these companies should break even in the 2007/08 campaign, and farmers might earn a small bonus reflecting the difference between the floor price and actual sales price.

\section{The authorities have taken steps to recapitalize SOFITEX, and intend} to reduce the government's ownership over time. Total recapitalization is expected to require CFAF 34 billion (1 percent of GDP) in 2007. The government is working with the World Bank and other donors on a strategy to rehabilitate SOFITEX, improve productivity, and reduce the government's role in the sector (end-December 2007 structural benchmark). It is important to improve the pricing mechanism further, in particular to ensure that a smoothing fund being set up by the interprofessional association, with the assistance of donors, can be sustained. To sustain the fund's resources, the discount between the producer floor price and the moving average of world prices could be linked to the financial condition of the fund. Technical work on this continues, including on measures to mitigate the effects on cotton output and farmers' income.

\section{Other Structural Reforms}

33. Financial sector reform will become more important, informed by the regional and Burkina Faso-specific FSAPs. The financial system is stable overall, relatively efficient and profitable, and the quality of the loan portfolio of

\footnotetext{
${ }^{13}$ This will also provide an opportunity to reassess appropriate targets for this expenditure category.
} 
Burkina Faso's banks is better than the WAEMU average. However, there has been some deterioration in bank soundness indicators - the recent regional FSAP showed that the weighted capital-adequacy ratio for Burkina Faso declined significantlyreflecting recent troubles in the cotton sector and weak balance sheets at new banks. Moreover, lack of access to finance constrains business development. Financial sector development will aim to strengthen the banking and insurance systems; increase access to finance for the rural sector, housing and SMEs; and improve the judicial system for credit. The national FSAP for Burkina Faso will present an opportunity to address Burkina Faso's implementation of the Anti-Money Laundering and Combating the Financing of Terrorism standards.

\section{Program Issues ANd Risks}

34. Given the anticipated widening in the current account deficit from sharply lower cotton production and higher oil prices, the authorities request to augment access by 15 percent of quota. The projected current account deficit for 2008 is expected to be about CFAF 35 billion (about 1 percent of GDP) larger than originally programmed. The requested augmentation would cushion the drawdown in reserves needed to finance the higher deficit. Current projections point to moderate financing gaps over the medium term. Together with the approved access of 10 percent of quota under the program, the augmentation would increase total access to 25 percent of quota, below the norm of 35 percent for countries under a fifth PRGF arrangement. The augmentation should not adversely impact Burkina Faso's capacity to repay the Fund.

35. Staff proposes to change the definition of the performance criterion for the overall deficit, including grants, from a payment-order basis (ordonnancement) to a commitment basis (engagement). Better quality data for the deficit are available on a commitment basis.

36. To keep the program on track, revenue administration reforms must be carried out and tax policy reform elaborated in a timely way. The revenue administration reforms fundamentally change work practices, which will become computer-based, and allow the new revenue administration to move towards self assessment. The required institutional change could test institutional capacity at revenue administration agencies. Regarding tax policy reform, delays in developing concrete proposals could push the 2009 fiscal targets out of reach.

\section{Staff Appraisal}

37. The macroeconomic environment in 2006 and 2007 was difficult, but overall policy performance was strong. In the face of the cotton sector crisis, rising oil prices, and other challenges, the authorities implemented adjustment measures as needed. The new cotton producer price mechanism is a major step to putting cotton 
ginning companies on a sustainable footing. Up until the recent spike in oil prices, the authorities have consistently adjusted domestic petroleum prices and raised electricity tariffs to cap subsidies. The fiscal stance has been in line with program targets; the revenue effort, though, fell short of expectations.

\section{The real exchange rate appears somewhat overvalued, but external}

imbalances are modest. The latter reflects broadly appropriate adjustment policies, the ability of Burkina Faso to draw on WAEMU reserves, and the fact that the CFA franc's value appears to be broadly appropriate for the WAEMU zone according to the assessment at the last WAEMU Article IV consultation.

39. Fiscal performance in the first six months of $\mathbf{2 0 0 7}$ was mixed. The performance criterion on the overall deficit target was observed; the indicative targets for revenue and poverty-reducing expenditures were narrowly missed. For the structural agenda, most measures were put in place, despite some delays. The authorities are requesting waivers for two performance criteria related to tax and customs administration; the required measure for customs administration reform has since been implemented, and the tax administration measure will be implemented starting in February 2008, under the oversight of the recently appointed new head of computerization. The cotton producer price mechanism - an important structural benchmark - was adopted as planned. Going forward, the authorities should aim for a more timely implementation of the structural agenda.

40. The planned fiscal stance for $\mathbf{2 0 0 8}$ strikes a balance between adjusting to a worse debt sustainability outlook and protecting expenditures under adverse economic conditions. The availability of additional grants from the World Bank and the African Development Bank related to Burkina Faso's moderate risk of debt distress rating eased this balancing act considerably. Further reductions in the fiscal deficit, including grants, will be needed to stabilize the NPV of debt to exports below its indicative threshold.

41. The staff supports the authorities' request for an augmentation of access. As cotton exports decline and oil imports rise, 2008 is expected to be a difficult year for Burkina Faso's economy. While the resulting projected drawdown in reserves poses no risk to economic stability, it is nevertheless appropriate for the Burkinabè authorities to manage this drawdown by drawing on Fund resources. Also, an augmentation could help to mobilize additional donor resources.

42. The structural agenda for $\mathbf{2 0 0 8}$ focuses on reforms to raise revenue. Efforts in tax and customs administration to consolidate computerization by integrating new tools into the work flow will require considerable management resources; constraints in this area could derail program implementation. The ambitious revenue targets starting in 2009 also require tax policy reform; the authorities intend to plan for such reforms in 2008 and implement them in 2009/10. In this context, the decision to lower 
the corporate income tax rate outside a comprehensive reform package was unfortunate as it removes one potentially positively perceived element of the reform.

43. The authorities' strategy for strengthening public finances is commendable, although further prioritization may be needed given resource constraints. The authorities' audit of domestic debt obligations uncovered some flaws in the expenditure system, which are being addressed. Staff welcomes the authorities' work on a study to expedite payments and to eliminate redundant controls. Given the authorities' comprehensive reform agenda, it will be important to focus on priority areas.

44. Moving the cotton sector reform agenda forward is a priority. With SOFITEX recapitalized and a new producer price mechanism established in 2007, the focus for 2008 will be to consolidate reforms and continue disengaging the government from the cotton sector. The World Bank and other donors have taken the lead in this area, and will assist the authorities with improving the design of the smoothing fund and the liberalization strategy.

45. The authorities intend to improve governance and the business environment. On governance, the merger of agencies engaged in financial control into an independent agency with increased powers is promising. It will be important to expand the agency's resources; it is welcome that it can take direct legal action and independently publish its reports. Improving government transparency by publishing reports on budget implementation would be beneficial. The authorities' work with the World Bank to improve Burkina Faso's Doing Business indicators is commendable, and should be continued to increase competitiveness.

46. Performance under the PRGF-supported program has been satisfactory. Against this background, and on the basis of policies set forth in the authorities' Letter of Intent, the staff recommends that their request for waivers be granted and that the first review under the PRGF arrangement be completed.

47. Staff proposes that the next Article IV consultation take place in accordance with the July 15, 2002, Executive Board decision on consultation cycles. 
Table 1. Burkina Faso: Selected Economic and Financial Indicators, 2004-12

\begin{tabular}{|c|c|c|c|c|c|c|c|c|c|c|c|c|c|}
\hline & \multirow{2}{*}{$\begin{array}{c}2004 \\
\text { Est. }\end{array}$} & \multirow{2}{*}{$\begin{array}{c}2005 \\
\text { Est. }\end{array}$} & \multirow{2}{*}{$\begin{array}{r}2006 \\
\text { Est. }\end{array}$} & \multicolumn{2}{|c|}{2007} & \multicolumn{2}{|c|}{2008} & \multicolumn{2}{|c|}{2009} & \multicolumn{2}{|c|}{2010} & \multirow{2}{*}{$\begin{array}{c}2011 \\
\text { Proj. }\end{array}$} & \multirow{2}{*}{$\begin{array}{l}2012 \\
\text { Proj. }\end{array}$} \\
\hline & & & & Prog. $^{1}$ & Proj. & Prog. ${ }^{1}$ & Proj. & Prog. ${ }^{1}$ & Proj. & $\overline{\text { Prog. }}{ }^{1}$ & Proj. & & \\
\hline & \multicolumn{13}{|c|}{ (Annual percentage change; unless otherwise specified) } \\
\hline \multicolumn{14}{|l|}{ GDP and prices } \\
\hline GDP at constant prices & 4.6 & 7.1 & 5.5 & 6.5 & 4.2 & 6.3 & 4.5 & 6.1 & 6.3 & 5.8 & 6.0 & 6.0 & 6.0 \\
\hline GDP deflator & 3.9 & 2.4 & 2.5 & 2.5 & -0.5 & 2.3 & 1.6 & 2.4 & 2.6 & 2.5 & 2.5 & 2.3 & 2.3 \\
\hline Consumer prices (annual average) & -0.4 & 6.4 & 2.4 & 2.0 & -0.7 & 2.0 & 2.0 & 2.0 & 2.0 & 2.0 & 2.0 & 2.0 & 2.0 \\
\hline Consumer prices (end of period) & 0.7 & 4.5 & 1.5 & 2.0 & 0.9 & 2.0 & 2.0 & 2.0 & 2.0 & 2.0 & 2.0 & 2.0 & 2.0 \\
\hline \multicolumn{14}{|l|}{ Money and credit } \\
\hline Net domestic assets (banking system) ${ }^{2}$ & 1.3 & 12.7 & 1.8 & -12.2 & -3.4 & 10.0 & 9.5 & 6.9 & 10.0 & 5.2 & 7.1 & 9.8 & 9.5 \\
\hline Credit to the government ${ }^{2}$ & -3.7 & 0.9 & -6.5 & -20.9 & -12.4 & 1.1 & 3.0 & -2.1 & -1.5 & 0.0 & -1.0 & 0.0 & 0.0 \\
\hline Credit to the private sector ${ }^{2}$ & 6.1 & 14.9 & 11.2 & 8.7 & 9.6 & 8.9 & 7.4 & 8.9 & 11.4 & 5.2 & 8.1 & 9.8 & 9.5 \\
\hline Broad money (M2) & -7.2 & -3.8 & 10.2 & 9.1 & 15.8 & 8.7 & 6.2 & 8.6 & 9.0 & 8.4 & 8.6 & 8.4 & 8.4 \\
\hline Velocity (GDP/M2) & 4.3 & 4.9 & 4.8 & 4.8 & 4.3 & 4.8 & 4.3 & 4.8 & 4.3 & 4.8 & 4.3 & 4.3 & 4.3 \\
\hline \multicolumn{14}{|l|}{ External sector } \\
\hline Exports (f.o.b.; valued in CFA francs) & 36.3 & -2.4 & 26.1 & 10.3 & -3.8 & 10.8 & 1.3 & 7.1 & 22.0 & 8.6 & 11.0 & 7.8 & 5.7 \\
\hline Imports (f.o.b.; valued in CFA francs) & 22.1 & 8.6 & 8.5 & 5.6 & 5.9 & 8.1 & 12.8 & 6.2 & 6.8 & 6.2 & 5.7 & 5.7 & 5.3 \\
\hline Terms of trade & 11.0 & -23.9 & 3.7 & 4.7 & -2.9 & 0.2 & -6.1 & 0.8 & 2.5 & 1.1 & 1.2 & 0.1 & -0.4 \\
\hline Real effective exchange rate $(-=$ depreciation $)$ & -0.5 & 2.9 & 0.2 & .. & $\ldots$ & .. & $\ldots$ & .. & $\ldots$ & .. & $\ldots$ & $\ldots$ & $\ldots$ \\
\hline World cotton price (US cents per pound) & 62.0 & 55.2 & 58.1 & 61.7 & 60.5 & 62.2 & 61.0 & 62.8 & 61.5 & 63.3 & 62.0 & 62.5 & 63.0 \\
\hline \multirow[t]{2}{*}{ Average petroleum spot price (US\$ per barrel) } & 37.8 & 53.4 & 64.3 & 60.8 & 71.3 & 64.8 & 88.5 & 64.5 & 83.0 & 64.3 & 81.0 & 80.5 & 80.3 \\
\hline & \multicolumn{13}{|c|}{ (Percent of GDP; unless otherwise indicated) } \\
\hline Gross investment & 15.3 & 19.8 & 16.3 & 23.2 & 18.4 & 23.3 & 19.1 & 23.4 & 19.4 & 22.8 & 19.9 & 19.8 & 19.9 \\
\hline Government & 7.7 & 7.6 & 7.9 & 8.6 & 9.1 & 8.3 & 9.0 & 8.4 & 8.8 & 8.1 & 8.9 & 8.8 & 8.8 \\
\hline Nongovernment sector & 7.6 & 12.2 & 8.3 & 14.5 & 9.3 & 15.0 & 10.2 & 15.0 & 10.6 & 14.7 & 11.0 & 11.0 & 11.0 \\
\hline Gross domestic savings & 1.8 & 5.2 & 3.3 & 9.4 & 3.8 & 10.2 & 2.9 & 10.6 & 4.7 & 10.5 & 6.1 & 6.6 & 7.1 \\
\hline Government savings & 2.5 & 1.5 & 1.1 & 4.9 & 0.6 & 5.9 & 1.1 & 7.0 & 2.8 & 7.2 & 3.2 & 3.7 & 4.0 \\
\hline Nongovernment savings & -0.7 & 3.7 & 2.2 & 4.5 & 3.3 & 4.3 & 1.8 & 3.6 & 1.8 & 3.3 & 2.9 & 2.9 & 3.1 \\
\hline Gross national savings & 4.9 & 8.4 & 6.7 & 12.5 & 8.4 & 12.8 & 6.9 & 13.3 & 7.3 & 12.9 & 8.4 & 8.5 & 9.0 \\
\hline \multicolumn{14}{|l|}{ Central government finances } \\
\hline Current revenue & 12.8 & 12.3 & 12.3 & 13.1 & 13.3 & 13.6 & 13.6 & 14.5 & 14.6 & 14.9 & 15.0 & 15.4 & 15.8 \\
\hline Of which: tax revenue & 11.8 & 11.4 & 11.3 & 12.0 & 12.2 & 12.4 & 12.6 & 13.3 & 13.6 & 13.7 & 13.9 & 14.3 & 14.7 \\
\hline Total expenditure (commitment basis) & 21.4 & 21.7 & 22.9 & 24.4 & 26.7 & 23.9 & 26.2 & 23.8 & 24.6 & 23.6 & 24.7 & 24.5 & 24.6 \\
\hline Of which: current expenditure & 10.5 & 11.2 & 12.1 & 12.2 & 13.5 & 12.1 & 12.9 & 11.8 & 12.0 & 12.1 & 12.1 & 12.0 & 12.0 \\
\hline Overall fiscal balance, excl. grants (commitments) & -8.6 & -9.4 & -10.7 & -11.3 & -13.4 & -10.3 & -12.7 & -9.2 & -10.0 & -8.7 & -9.7 & -9.1 & -8.8 \\
\hline Overall fiscal balance, incl. grants (commitments) ${ }^{3}$ & -4.3 & -4.9 & -5.1 & -6.2 & -6.2 & -5.7 & -5.4 & -4.7 & -4.5 & -4.3 & -4.1 & -3.9 & -3.7 \\
\hline Overall fiscal balance, incl. grants (payment-orders) ${ }^{3}$ & -4.0 & -4.8 & -4.4 & -6.2 & -6.2 & -5.7 & -5.4 & -4.7 & -4.5 & -4.3 & -4.1 & -3.9 & -3.7 \\
\hline Domestic financing & -0.4 & -0.5 & -1.4 & 1.5 & 3.3 & 0.2 & 1.5 & -0.4 & -0.3 & 0.0 & -0.2 & 0.0 & 0.0 \\
\hline \multicolumn{14}{|l|}{ External sector } \\
\hline Exports of goods and services & 10.7 & 10.0 & 11.7 & 11.9 & 10.7 & 12.1 & 10.3 & 12.0 & 11.4 & 12.0 & 11.7 & 11.7 & 11.5 \\
\hline Imports of goods and services & 24.3 & 24.6 & 24.6 & 25.6 & 25.4 & 25.2 & 26.6 & 24.7 & 26.1 & 24.3 & 25.4 & 24.8 & 24.2 \\
\hline Current account balance (excl. official & -13.4 & -14.6 & -12.5 & -13.8 & -14.1 & -13.4 & -16.0 & -12.8 & -14.5 & -12.4 & -13.8 & -13.0 & -12.5 \\
\hline Current account balance (incl. official transfers) & -10.4 & -11.4 & -9.6 & -10.6 & -10.1 & -10.5 & -12.2 & -10.0 & -12.1 & -9.9 & -11.5 & -11.3 & -10.8 \\
\hline \multicolumn{14}{|l|}{ Debt indicators } \\
\hline External debt & 41.2 & 37.6 & 19.9 & 20.7 & 20.9 & 24.4 & 23.6 & 27.5 & 26.5 & 29.5 & 28.7 & 29.7 & 30.9 \\
\hline NPV of external debt & 18.1 & 19.0 & 10.6 & 12.2 & 11.5 & 14.3 & 13.1 & 16.2 & 14.8 & 17.3 & 16.1 & 17.0 & 17.8 \\
\hline NPV of external debt as percent of exports & 164.4 & 185.4 & 88.1 & 101.0 & 104.6 & 116.6 & 124.2 & 132.8 & 127.6 & 141.2 & 135.8 & 142.9 & 152.1 \\
\hline NPV of external debt as percent of revenues & 141.6 & 154.2 & 86.1 & 93.8 & 86.5 & 105.9 & 96.6 & 111.3 & 101.7 & 115.7 & 107.8 & 110.4 & 112.5 \\
\hline Nominal GDP (billions of CFA francs) & 2,698 & 2,959 & 3,199 & 3,451 & 3,317 & 3,751 & 3,521 & 4,074 & 3,840 & 4,415 & 4,169 & 4,521 & 4,902 \\
\hline
\end{tabular}

Sources: Burkinabè authorities; and IMF staff estimates and projections.

${ }^{1}$ IMF Country Report No. 07/153, May 9, 2007.

${ }^{2}$ Percent of beginning-of-period broad money.

${ }^{3}$ Excluding MDRI grants. 
Table 2. Burkina Faso: Consolidated Operations of the Central Government, 2004-12

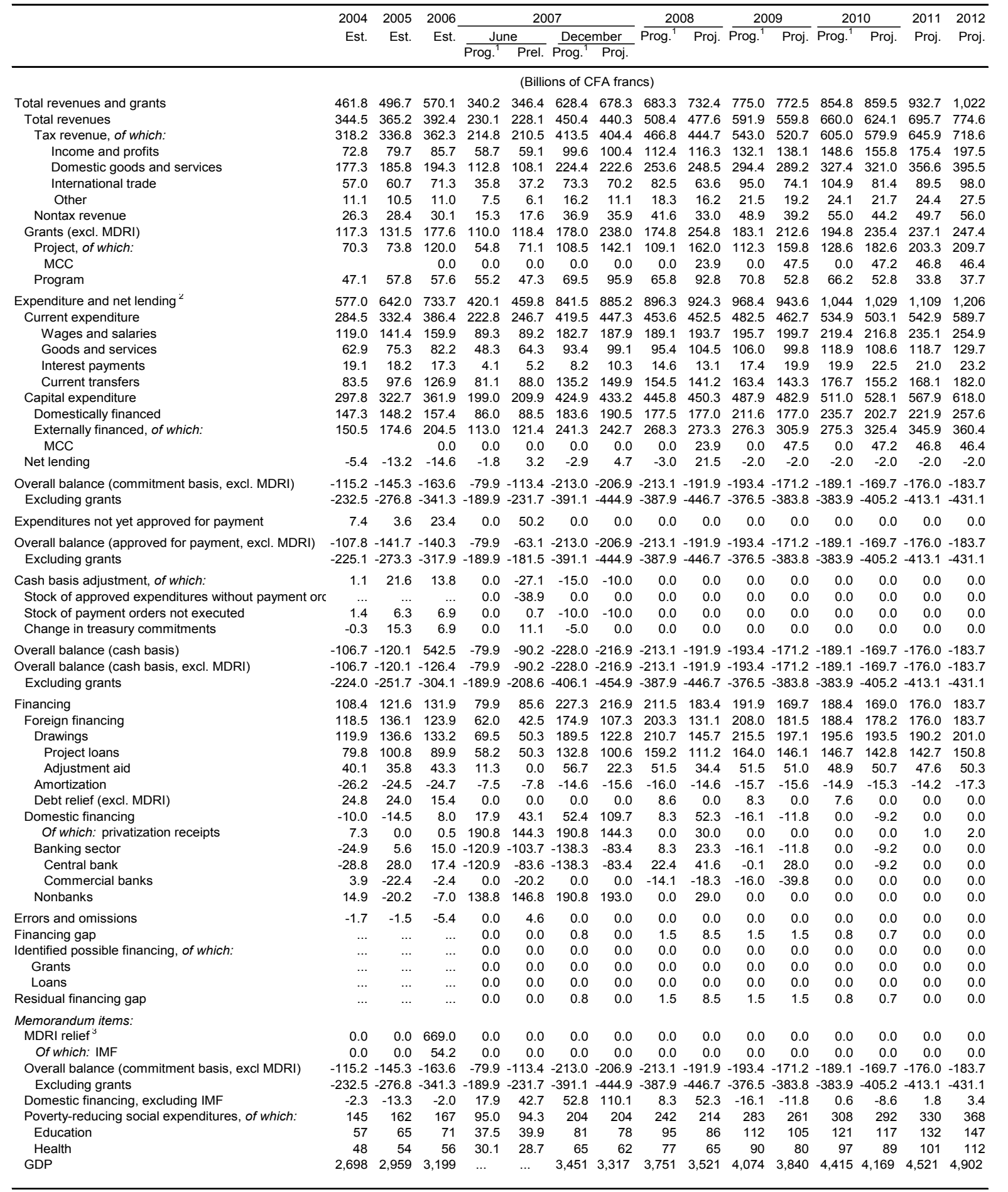

Sources: Burkinabè authorities; and IMF staff estimates and projections.

${ }^{1}$ IMF Country Report No. 07/153, May 9, 2007.

${ }^{2}$ On a commitment (engagement) basis.

${ }^{3}$ Multilateral Debt Relief Initiative stock-of-debt operation, including cancellation of debt treated under the enhanced HIPC Initiative, shown on accrual basis. Includes relief from IMF, World Bank, and African Development Bank. For the World Bank and African Development Bank, implementation of the stock-of-debt operation is assumed for July 1, 2006. The operation increases domestic and external amortization payments in 2006, which are offset by MDRI grants, and lowers amortization and interest from 2006 onwards. MDRI relief from the Fund is higher than in the balance of payments because of a valuation adjustment by the BCEAO. 
Table 2. Burkina Faso: Consolidated Operations of the Central Government, 2004-12 (Concluded)

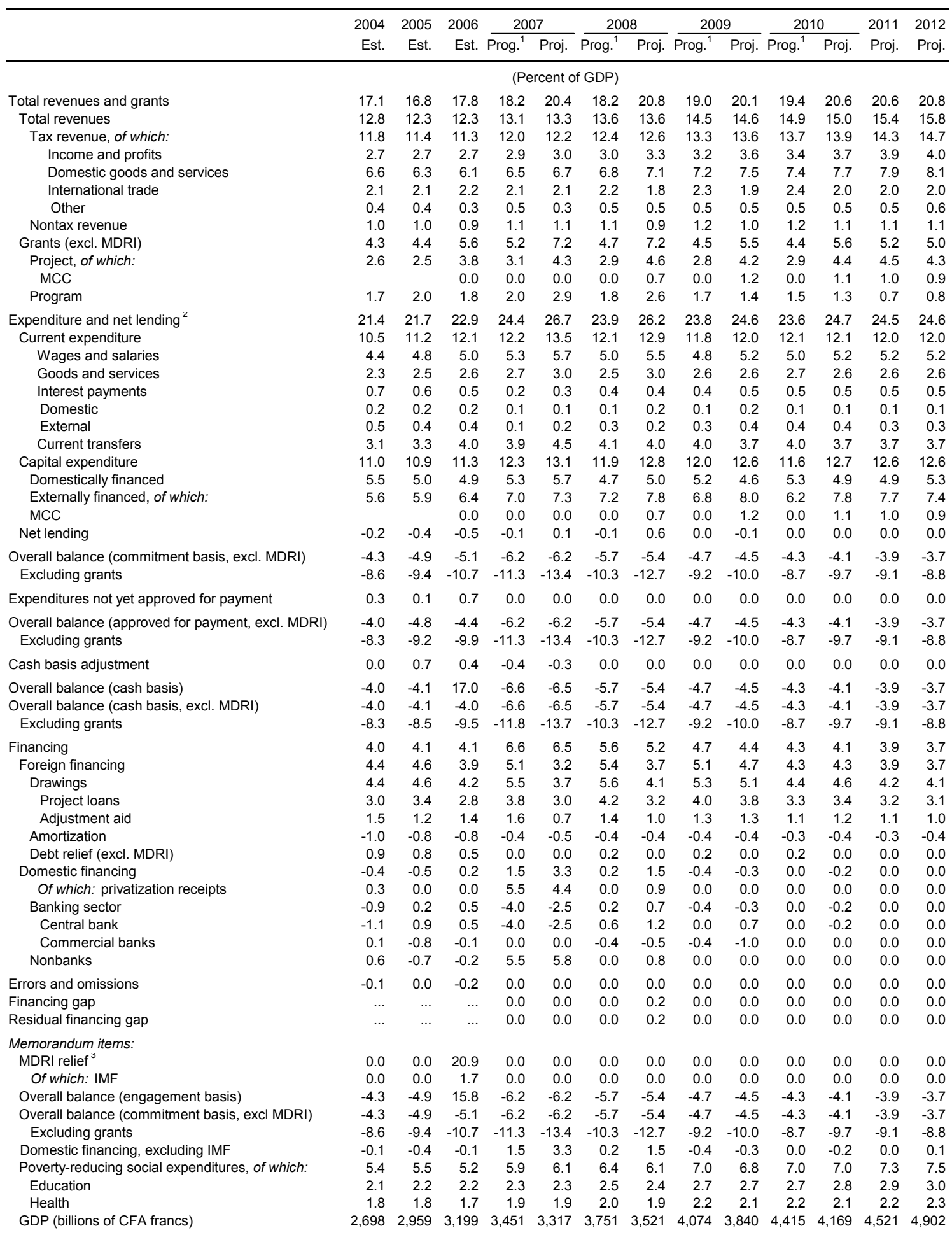

Sources: Burkinabè authorities; and IMF Staff estimates and projections.

${ }^{1}$ IMF Country Report No. 07/153, May 9, 2007.

${ }^{2}$ On a commitment (engagement) basis.

${ }^{3}$ Multilateral Debt relief Initiative stock-of-debt operation, including cancellation of debt treated under the enhanced HIPC Initiative, shown on accrual basis. Includes relief from IMF, World Bank, and African Development Bank. For the World Bank and African Development Bank, implementation of the stock-of-debt operation is assumed for July 1,2006 . The operation increases domestic and external amortization payments in 2006 , which are offset by MDRI grants, and lowers amortization and interest from 2006 onwards. MDRI relief from the Fund is higher than in the balance of payments because of a valuation adjustment by the BCEAO. 
Table 3. Burkina Faso: Monetary Survey, 2004-08

\begin{tabular}{|c|c|c|c|c|c|c|c|c|c|}
\hline & \multirow{2}{*}{$\begin{array}{c}2004 \\
\text { Dec. }\end{array}$} & \multirow{2}{*}{$\begin{array}{c}2005 \\
\text { Dec. }\end{array}$} & \multirow{2}{*}{$\begin{array}{r}2006 \\
\text { Dec. } \\
\text { Est. }\end{array}$} & \multicolumn{4}{|c|}{2007} & \multicolumn{2}{|c|}{2008} \\
\hline & & & & $\begin{array}{l}\text { Mar. } \\
\text { Est. }\end{array}$ & $\begin{array}{c}\text { Jun. } \\
\text { Est. }\end{array}$ & $\begin{array}{l}\text { Dec. } \\
\text { Prog. }{ }^{1}\end{array}$ & $\begin{array}{l}\text { Dec. } \\
\text { Proj. }\end{array}$ & $\begin{array}{r}\text { Dec. } \\
\text { Prog. }^{1}\end{array}$ & $\begin{array}{l}\text { Dec. } \\
\text { Proj. }\end{array}$ \\
\hline & \multicolumn{7}{|c|}{ (Billions of CFA francs) } & & \\
\hline Net foreign assets ${ }^{2}$ & 274 & 171 & 221 & 384 & 432 & 362 & 348 & 352 & 322 \\
\hline Central Bank of West African States (BCEAO) & 232 & 165 & 203 & 350 & 392 & 344 & 323 & 334 & 298 \\
\hline Assets & 318 & 244 & 275 & 427 & 465 & 416 & 396 & 406 & 370 \\
\hline Liabilities $^{3,4}$ & 86 & 79 & 72 & 76 & 73 & 72 & 73 & 72 & 73 \\
\hline Commercial banks & 42 & 6 & 18 & 34 & 40 & 18 & 25 & 18 & 25 \\
\hline Net domestic assets & 350 & 430 & 441 & 376 & 351 & 360 & 418 & 432 & 491 \\
\hline Net domestic credit & 385 & 484 & 512 & 444 & 389 & 433 & 493 & 505 & 573 \\
\hline Net credit to government ${ }^{3}$ & 3 & 9 & -30 & -107 & -134 & -167 & -112 & -159 & -89 \\
\hline Treasury & 57 & 72 & 22 & -45 & -66 & -116 & -61 & -108 & -38 \\
\hline BCEAO & 15 & 50 & 8 & -49 & -73 & -130 & -75 & -108 & -33 \\
\hline Commercial banks & 42 & 22 & 14 & 4 & 7 & 14 & 14 & -1 & -5 \\
\hline Other central government & -54 & -63 & -52 & -62 & -68 & -51 & -51 & -51 & -51 \\
\hline Of which: project deposits & -86 & -91 & -102 & -104 & -118 & -101 & -101 & -101 & -101 \\
\hline Crop credit & 15 & 63 & 75 & 47 & 52 & 84 & 83 & 93 & 91 \\
\hline Other & 367 & 413 & 467 & 504 & 471 & 516 & 523 & 571 & 571 \\
\hline Other items (net) ${ }^{5}$ & -35 & -55 & -71 & -68 & -38 & -73 & -75 & -73 & -82 \\
\hline Broad money $^{2}$ & 624 & 600 & 662 & 760 & 783 & 721 & 766 & 784 & 813 \\
\hline \multirow[t]{2}{*}{ Of which: bank deposits } & 399 & 401 & 469 & 518 & 532 & 515 & 549 & 563 & 585 \\
\hline & \multicolumn{9}{|c|}{ (Annual changes in percent of broad money of 12 months earlier, unless otherwise specified) } \\
\hline \multicolumn{10}{|l|}{ Memorandum items: } \\
\hline Net foreign assets & -8.4 & -16.6 & 8.4 & 24.0 & 31.6 & 21.3 & 19.2 & -1.3 & -3.4 \\
\hline Net domestic assets & 1.3 & 12.7 & 1.8 & -6.9 & -10.8 & -12.2 & -3.4 & 10.0 & 9.5 \\
\hline Net credit to government & -3.7 & 0.9 & -6.5 & -13.3 & -16.5 & -20.9 & -12.4 & 1.1 & 3.0 \\
\hline Credit to the economy & 6.1 & 14.9 & 11.2 & 6.8 & 2.8 & 8.7 & 9.6 & 8.9 & 7.4 \\
\hline (annual percentage change) & 12.0 & 24.4 & 14.1 & 8.7 & 3.6 & 10.7 & 11.7 & 10.6 & 9.4 \\
\hline (excluding crop credit) & 21.9 & 12.5 & 13.1 & 20.9 & 14.7 & 10.6 & 12.0 & 10.6 & 9.2 \\
\hline Money supply & -7.2 & -3.8 & 10.2 & 17.1 & 20.9 & 9.1 & 15.8 & 8.7 & 6.2 \\
\hline Of which: bank deposits & 4.7 & 0.2 & 11.4 & 12.4 & 12.6 & 6.9 & 12.1 & 6.6 & 4.7 \\
\hline Currency velocity (GDP/broad money) & 4.3 & 4.9 & 4.8 & $\ldots$ & $\ldots$ & 4.8 & 4.3 & 4.8 & 4.3 \\
\hline
\end{tabular}

Sources: Burkinabè authorities; and IMF staff estimates and projections.

' IMF Country Report No. 07/153, May 9, 2007.

${ }^{2}$ From December 2003 onwards, reflects revised BCEAO estimates of currency in circulation.

${ }^{3} \mathrm{MDRI}$ relief from the Fund is reflected from 2006 onwards.

${ }^{4}$ For 2006, assumes augmented access under the Fund arrangement.

${ }^{5}$ Includes valuation adjustment related to MDRI relief. 
Table 4. Burkina Faso: Balance of Payments, 2004-12

\begin{tabular}{|c|c|c|c|c|c|c|c|c|c|c|c|c|}
\hline & \multirow{2}{*}{$\begin{array}{r}2004 \\
\text { Est. }\end{array}$} & \multirow{2}{*}{$\begin{array}{r}2005 \\
\text { Est. }\end{array}$} & \multirow{2}{*}{$\begin{array}{c}2006 \\
\text { Est. }\end{array}$} & \multicolumn{2}{|c|}{2007} & \multicolumn{2}{|c|}{2008} & \multicolumn{2}{|c|}{2009} & \multirow{2}{*}{$\begin{array}{r}2010 \\
\text { Proj. }\end{array}$} & \multirow{2}{*}{$\begin{array}{l}2011 \\
\text { Proj. }\end{array}$} & \multirow{2}{*}{$\begin{array}{l}2012 \\
\text { Proj }\end{array}$} \\
\hline & & & & Prog. ${ }^{1}$ & Proj. & Prog. ${ }^{1}$ & Proj. & Prog. ${ }^{1}$ & $\overline{\text { Proj. }}$ & & & \\
\hline & & & \multicolumn{10}{|c|}{ (Billions of CFA francs) } \\
\hline Exports, f.o.b. & 253 & 247 & 312 & 352 & 300 & 390 & 304 & 417 & 371 & 412 & 444 & 469 \\
\hline Of which: cotton & 159 & 149 & 190 & 216 & 169 & 231 & 112 & 247 & 150 & 159 & 169 & 179 \\
\hline gold & & 10 & 14 & 17 & 21 & 35 & 74 & 49 & 99 & 120 & 124 & 125 \\
\hline Imports, f.o.b. & -498 & -541 & -586 & -655 & -621 & -709 & -700 & -753 & -748 & -791 & -835 & -880 \\
\hline Of which: petroleum products & -111 & -121 & -145 & -160 & -156 & -178 & -196 & -186 & -192 & -197 & -205 & -212 \\
\hline Trade balance & -245 & -293 & -275 & -304 & -321 & -319 & -396 & -335 & -377 & -379 & -392 & -411 \\
\hline Services and income (net) & -137 & -160 & -159 & -183 & -179 & -195 & -193 & -201 & -210 & -222 & -230 & -241 \\
\hline Services & -121 & -138 & -138 & -170 & -165 & -175 & -176 & -185 & -186 & -196 & -205 & -214 \\
\hline Income & -16 & -22 & -21 & -13 & -15 & -20 & -17 & -16 & -24 & -26 & -25 & -27 \\
\hline Current transfers (net) & 100 & 116 & 128 & 119 & 167 & 119 & 158 & 127 & 123 & 122 & 109 & 120 \\
\hline Private & 20 & 21 & 32 & 11 & 32 & 13 & 25 & 15 & 29 & 27 & 32 & 37 \\
\hline Official & 80 & 95 & 96 & 109 & 135 & 106 & 133 & 112 & 94 & 95 & 78 & 83 \\
\hline Current account $(-=$ deficit $)$ & -281 & -337 & -306 & -367 & -334 & -395 & -431 & -409 & -464 & -479 & -512 & -532 \\
\hline Excluding current official transfers & -362 & -432 & -401 & -476 & -469 & -501 & -564 & -521 & -558 & -574 & -590 & -615 \\
\hline Capital transfers & 106 & 115 & 818 & 128 & 161 & 138 & 182 & 142 & 181 & 205 & 226 & 234 \\
\hline Project grants & 70 & 74 & 120 & 108 & 142 & 109 & 162 & 112 & 160 & 183 & 203 & 210 \\
\hline Other capital transfers & 36 & 41 & 698 & 19 & 19 & 29 & 20 & 29 & 21 & 22 & 23 & 24 \\
\hline Of which: MDRI debt relief (incl. IMF) & $\ldots$ & $\ldots$ & 664 & $\ldots$ & $\ldots$ & $\ldots$ & $\ldots$ & $\ldots$ & $\ldots$ & $\ldots$ & $\ldots$ & $\ldots$ \\
\hline Of which: IMF MDRI debt relief & $\ldots$ & $\ldots$ & 50 & $\ldots$ & $\ldots$ & $\ldots$ & $\ldots$ & $\ldots$ & $\ldots$ & $\ldots$ & $\ldots$ & ... \\
\hline Of which: remaining HIPC Initiative relief & 25 & 24 & 15 & 0 & 0 & 9 & 0 & 8 & 0 & 0 & 0 & 0 \\
\hline Financial operations & 114 & 116 & -428 & 380 & 300 & 246 & 215 & 280 & 267 & 276 & 261 & 277 \\
\hline Official capital & 94 & 112 & -506 & 175 & 107 & 195 & 131 & 200 & 182 & 178 & 176 & 184 \\
\hline Disbursements & 120 & 137 & 133 & 189 & 123 & 211 & 146 & 215 & 197 & 194 & 190 & 201 \\
\hline Project loans & 80 & 101 & 90 & 133 & 101 & 159 & 111 & 164 & 146 & 143 & 143 & 151 \\
\hline Program loans & 40 & 36 & 43 & 57 & 22 & 51 & 34 & 51 & 51 & 51 & 48 & 50 \\
\hline Amortization & -14 & -34 & -590 & -15 & -16 & -16 & -15 & -16 & -16 & -15 & -12 & -14 \\
\hline Of which: MDRI debt relief (IDA and AfDB) & $\ldots$ & $\ldots$ & -615 & $\ldots$ & $\ldots$ & $\ldots$ & $\ldots$ & $\ldots$ & $\ldots$ & $\ldots$ & $\ldots$ & $\ldots$ \\
\hline Private capital $^{2}$ & 21 & 4 & 78 & 205 & 192 & 52 & 84 & 80 & 86 & 98 & 85 & 93 \\
\hline Errors and omissions & 4 & 2 & -34 & 0 & 0 & 0 & 0 & 0 & 0 & 0 & 0 & 0 \\
\hline Overall balance & -57 & -103 & 50 & 140 & 127 & -11 & -34 & 12 & -16 & 2 & -24 & -21 \\
\hline Financing & 57 & 103 & -50 & -141 & -127 & 10 & 26 & -14 & 7 & -13 & 13 & 11 \\
\hline Net foreign assets & 57 & 103 & -50 & -141 & -127 & 10 & 26 & -14 & 7 & -13 & 13 & 11 \\
\hline Net official reserves, of which: & 61 & 67 & -38 & -141 & -120 & 10 & 26 & -14 & 7 & -13 & 13 & 11 \\
\hline Gross official reserves & 73 & 75 & -32 & -141 & -121 & 10 & 26 & -14 & 7 & -13 & 15 & 14 \\
\hline IMF (net) & -8 & -1 & -40 & 0.0 & 0.4 & 0.0 & 0.0 & 0.0 & 0.0 & -0.5 & -1.8 & -3.4 \\
\hline Of which: IMF MDRI stock of debt relief & $\ldots$ & $\ldots$ & -50 & $\ldots$ & $\ldots$ & $\ldots$ & $\ldots$ & $\ldots$ & $\ldots$ & $\ldots$ & $\ldots$ & $\cdots$ \\
\hline Net foreign assets, commercial banks & -4 & 36 & -12 & 0 & -7 & 0 & 0 & 0 & 0 & 0 & 0 & 0 \\
\hline Change in arrears $(-=$ reduction $)$ & 0 & 0 & 0 & 0 & 0 & 0 & 0 & 0 & 0 & 0 & 0 & 0 \\
\hline Financing gap & 0 & 0 & 0 & 0.7 & 0.0 & 1.5 & 8.5 & 1.5 & 8.4 & 11.1 & 10.8 & 10.0 \\
\hline Identified possible financing & $\ldots$ & $\ldots$ & 0 & 0 & 0 & 0 & 0 & 0 & 0 & 0 & 0 & 0 \\
\hline Residual financing gap & $\ldots$ & $\ldots$ & 0 & 0.7 & 0.0 & 1.5 & 8.5 & 1.5 & 8.4 & 11.1 & 10.8 & 10.0 \\
\hline Memorandum items: & & & & & Percen & nt of GD & P; unle & ess othe & erwise ir & ndicate & & \\
\hline Debt service relief from MDRI & $\ldots$ & $\ldots$ & 0.3 & $\ldots$ & $\ldots$ & $\ldots$ & $\cdots$ & $\ldots$ & $\ldots$ & $\ldots$ & $\ldots$ & $\ldots$ \\
\hline Trade balance $(-=$ deficit $)$ & -9.1 & -9.9 & -8.6 & -8.8 & -9.7 & -8.5 & -11.3 & -8.2 & -9.8 & -9.1 & -8.7 & -8.4 \\
\hline Cotton export volume (thousands of metric tons) & 203.3 & 257.8 & 298.3 & 330.2 & 273.0 & 352.2 & 183.5 & 374.8 & 243.6 & 258.5 & 274.3 & 291.1 \\
\hline Current account $(-=$ deficit $)$ & -10.4 & -11.4 & -9.6 & -10.6 & -10.1 & -10.5 & -12.2 & -10.0 & -12.1 & -11.5 & -11.3 & -10.8 \\
\hline Excluding current official transfers & -13.4 & -14.6 & -12.5 & -13.8 & -14.1 & -13.4 & -16.0 & -12.8 & -14.5 & -13.8 & -13.0 & -12.5 \\
\hline Overall balance $(-=$ deficit $)$ & -2.1 & -3.5 & 1.6 & 4.1 & 3.8 & -0.3 & -1.0 & 0.3 & -0.4 & 0.1 & -0.5 & -0.4 \\
\hline Total debt-service ratio after HIPC ${ }^{3}$ & 5.7 & 5.8 & 170.5 & 5.3 & 6.9 & 4.6 & 6.8 & 3.4 & 7.5 & 7.2 & 6.2 & 6.7 \\
\hline Gross international reserves (billions of CFA francs) & 318.1 & 243.6 & 275.3 & 415.9 & 396.0 & 406.4 & 370.2 & 419.9 & 362.9 & 375.6 & 360.4 & 346.0 \\
\hline Months of imports of goods and services & 5.8 & 4.0 & 4.2 & 5.7 & 5.7 & 5.2 & 4.8 & 5.0 & 4.4 & 4.3 & 3.9 & 3.5 \\
\hline GDP at current prices (billions of CFA francs) & 2,698 & 2,959 & 3,199 & 3,451 & 3,317 & 3,751 & 3,521 & 4,074 & 3,840 & 4,169 & 4,521 & 4,902 \\
\hline
\end{tabular}

Sources: Central Bank of West African States (BCEAO); and IMF staff estimates and projections.

${ }^{1}$ IMF Country Report No. 07/153, May 9, 2007.

${ }^{2}$ Includes portfolio investment and foreign direct investment.

${ }^{3}$ Percent of exports of goods and services. 
33

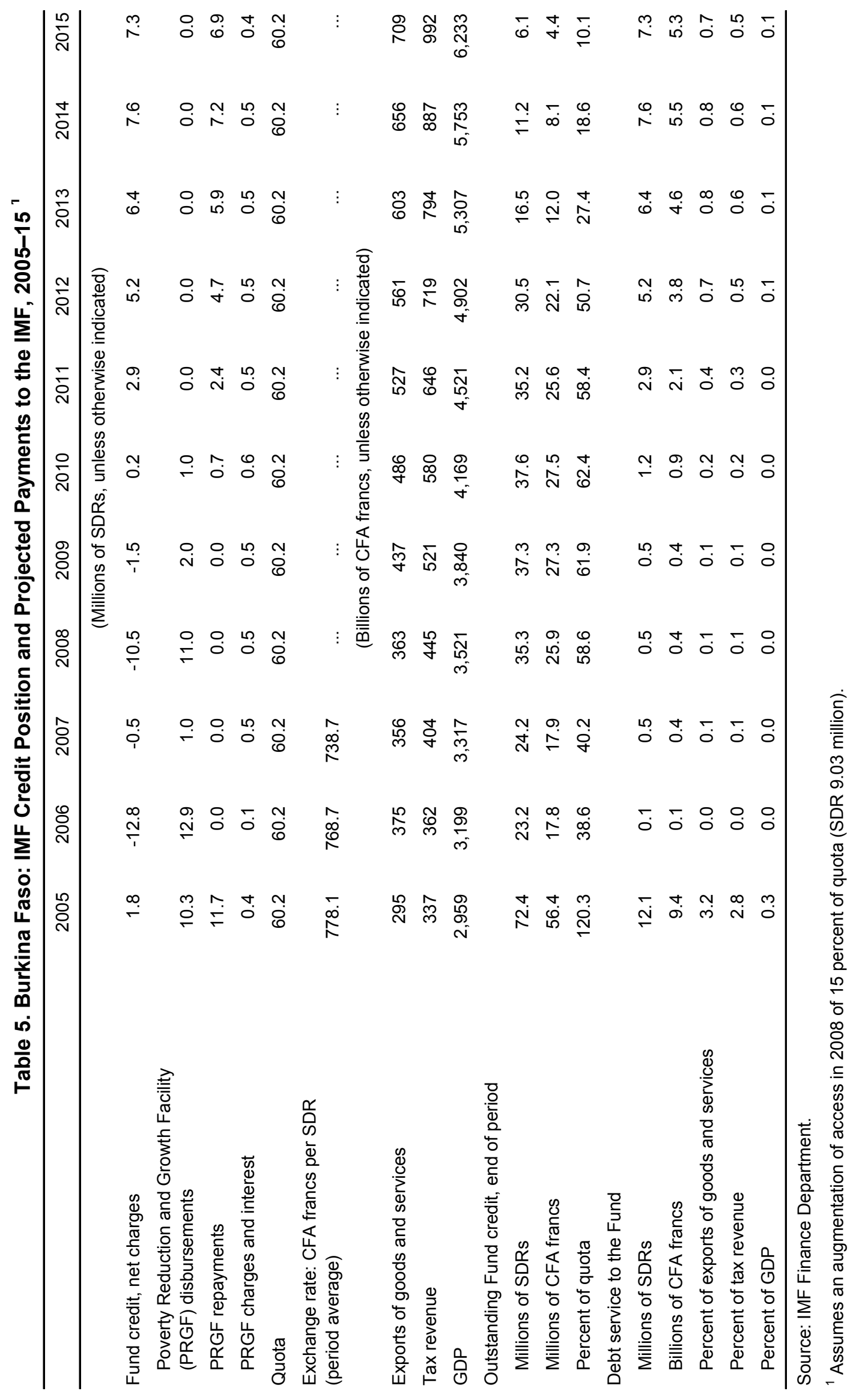


Table 6. Burkina Faso: Schedule of Disbursements Under the PRGF Arrangement, 2007-10

\begin{tabular}{|c|c|c|}
\hline Amount & Date Available & Conditions Necessary for Disbursement ${ }^{1}$ \\
\hline SDR 0.5 million & April 23, 2007 & $\begin{array}{l}\text { Following Executive Board approval of the three-year PRGF } \\
\text { arrangement }\end{array}$ \\
\hline SDR 3.51 million & December 31, 2007 & $\begin{array}{l}\text { Observance of the performance criteria for June } 30,2007 \text {, } \\
\text { and completion of the first review under the arrangement }\end{array}$ \\
\hline SDR 4.014 million & May 31, 2008 & $\begin{array}{l}\text { Observance of the performance criteria for December } 31 \text {, } \\
2007 \text {, and completion of the second review under the } \\
\text { arrangement }\end{array}$ \\
\hline SDR 4.014 million & November 30, 2008 & $\begin{array}{l}\text { Observance of the performance criteria for June } 30,2008 \text {, } \\
\text { and completion of the third review under the arrangement }\end{array}$ \\
\hline SDR 1.004 million & May 31, 2009 & $\begin{array}{l}\text { Observance of the performance criteria for December } 31 \text {, } \\
2008 \text {, and completion of the fourth review under the } \\
\text { arrangement }\end{array}$ \\
\hline SDR 1.004 million & November 30, 2009 & $\begin{array}{l}\text { Observance of the performance criteria for June } 30,2009 \text {, } \\
\text { and completion of the fifth review under the arrangement }\end{array}$ \\
\hline SDR 1.004 million & March 30, 2010 & $\begin{array}{l}\text { Observance of the performance criteria for December } 31 \text {, } \\
2009 \text {, and completion of the sixth review under the } \\
\text { arrangement }\end{array}$ \\
\hline
\end{tabular}

Source: IMF

${ }^{1}$ In addition to the generally applicable conditions under the Poverty Reduction and Growth Facility arrangement.

${ }^{2}$ Assumes augmentation of access of 15 percent of quota (SDR 9.03 million), phased equally over the three disbursements expected in 2008. 
Table 7. Burkina Faso: Poverty-Reducing Social Expenditures, 2001-07.

\begin{tabular}{|c|c|c|c|c|c|c|c|}
\hline & 2001 & 2002 & 2003 & 2004 & 2005 & $\begin{array}{r}2006 \\
\text { Est. }\end{array}$ & $\begin{array}{r}2007 \\
\text { Proj. }\end{array}$ \\
\hline & \multicolumn{7}{|c|}{ (Billions of CFA francs) } \\
\hline Total poverty-reducing social expenditure & 80.4 & 108.9 & 116.6 & 145.0 & 161.8 & 167.2 & 203.8 \\
\hline Current expenditure & 64.9 & 76.7 & 83.8 & 94.0 & 112.6 & 121.7 & 143.7 \\
\hline Capital expenditure & 15.5 & 32.2 & 32.8 & 50.9 & 49.2 & 45.5 & 60.2 \\
\hline Health & 27.3 & 38.5 & 37.9 & 48.1 & 54.2 & 55.7 & 61.9 \\
\hline Current expenditure & 24.1 & 31.5 & 29.9 & 31.9 & 39.4 & 43.6 & 48.9 \\
\hline Capital expenditure & 3.2 & 6.9 & 8.0 & 16.3 & 14.8 & 12.1 & 13.0 \\
\hline Education & 35.1 & 42.7 & 47.9 & 56.9 & 64.5 & 70.6 & 77.5 \\
\hline Current expenditure & 29.8 & 30.5 & 37.6 & 44.2 & 53.1 & 59.5 & 66.9 \\
\hline Capital expenditure & 5.3 & 12.2 & 10.3 & 12.7 & 11.4 & 11.1 & 10.6 \\
\hline Rural roads & 1.9 & 1.8 & 2.3 & 3.3 & 3.7 & 3.9 & 5.7 \\
\hline Current expenditure & 0.0 & 0.0 & 0.0 & 0.0 & 0.0 & 0.1 & 0.1 \\
\hline Capital expenditure & 1.9 & 1.8 & 2.3 & 3.3 & 3.6 & 3.7 & 5.6 \\
\hline \multicolumn{8}{|l|}{ Women's welfare and other poverty-reducing } \\
\hline social expenditure & 16.2 & 25.9 & 28.5 & 36.6 & 39.4 & 37.0 & 58.6 \\
\hline Current expenditure & 11.1 & 14.7 & 16.3 & 18.0 & 20.1 & 18.5 & 27.7 \\
\hline \multirow[t]{2}{*}{ Capital expenditure } & 5.1 & 11.2 & 12.2 & 18.6 & 19.3 & 18.6 & 30.9 \\
\hline & \multicolumn{7}{|c|}{ (As percentage of GDP) } \\
\hline Total poverty-reducing social expenditure & 3.9 & 4.7 & 4.7 & 5.4 & 5.5 & 5.2 & 6.1 \\
\hline Current expenditure & 3.1 & 3.3 & 3.4 & 3.5 & 3.8 & 3.8 & 4.3 \\
\hline Capital expenditure & 0.8 & 1.4 & 1.3 & 1.9 & 1.7 & 1.4 & 1.8 \\
\hline Health & 1.3 & 1.7 & 1.5 & 1.8 & 1.8 & 1.7 & 1.9 \\
\hline Current expenditure & 1.2 & 1.4 & 1.2 & 1.2 & 1.3 & 1.4 & 1.5 \\
\hline Capital expenditure & 0.2 & 0.3 & 0.3 & 0.6 & 0.5 & 0.4 & 0.4 \\
\hline Education & 1.7 & 1.9 & 1.9 & 2.1 & 2.2 & 2.2 & 2.3 \\
\hline Current expenditure & 1.4 & 1.3 & 1.5 & 1.6 & 1.8 & 1.9 & 2.0 \\
\hline Capital expenditure & 0.3 & 0.5 & 0.4 & 0.5 & 0.4 & 0.3 & 0.3 \\
\hline Rural roads & 0.1 & 0.1 & 0.1 & 0.1 & 0.1 & 0.1 & 0.2 \\
\hline Current expenditure & 0.0 & 0.0 & 0.0 & 0.0 & 0.0 & 0.0 & 0.0 \\
\hline Capital expenditure & 0.1 & 0.1 & 0.1 & 0.1 & 0.1 & 0.1 & 0.2 \\
\hline \multicolumn{8}{|l|}{ Women's welfare and other poverty-reducing } \\
\hline social expenditure & 0.8 & 1.1 & 1.1 & 1.4 & 1.3 & 1.2 & 1.8 \\
\hline Current expenditure & 0.5 & 0.6 & 0.7 & 0.7 & 0.7 & 0.6 & 0.8 \\
\hline \multirow[t]{2}{*}{ Capital expenditure } & 0.2 & 0.5 & 0.5 & 0.7 & 0.7 & 0.6 & 0.9 \\
\hline & \multicolumn{7}{|c|}{ (As percentage of total expenditure) } \\
\hline Total poverty-reducing social expenditure & 17.5 & 22.3 & 24.1 & 24.9 & 24.7 & 22.3 & 23.1 \\
\hline Current expenditure & 14.1 & 15.7 & 17.3 & 16.1 & 17.2 & 16.3 & 16.3 \\
\hline Capital expenditure & 3.4 & 6.6 & 6.8 & 8.7 & 7.5 & 6.1 & 6.8 \\
\hline Health & 5.9 & 7.9 & 7.8 & 8.3 & 8.3 & 7.4 & 7.0 \\
\hline Current expenditure & 5.2 & 6.4 & 6.2 & 5.5 & 6.0 & 5.8 & 5.6 \\
\hline Capital expenditure & 0.7 & 1.4 & 1.7 & 2.8 & 2.3 & 1.6 & 1.5 \\
\hline Education & 7.6 & 8.7 & 9.9 & 9.8 & 9.8 & 9.4 & 8.8 \\
\hline Current expenditure & 6.5 & 6.2 & 7.8 & 7.6 & 8.1 & 8.0 & 7.6 \\
\hline Capital expenditure & 1.2 & 2.5 & 2.1 & 2.2 & 1.7 & 1.5 & 1.2 \\
\hline Rural roads & 0.4 & 0.4 & 0.5 & 0.6 & 0.6 & 0.5 & 0.7 \\
\hline Current expenditure & 0.0 & 0.0 & 0.0 & 0.0 & 0.0 & 0.0 & 0.0 \\
\hline Capital expenditure & 0.4 & 0.4 & 0.5 & 0.6 & 0.6 & 0.5 & 0.6 \\
\hline \multicolumn{8}{|l|}{ Women's welfare and other poverty-reducing } \\
\hline social expenditure & 3.5 & 5.3 & 5.9 & 6.3 & 6.0 & 4.9 & 6.7 \\
\hline Current expenditure & 2.4 & 3.0 & 3.4 & 3.1 & 3.1 & 2.5 & 3.1 \\
\hline Capital expenditure & 1.1 & 2.3 & 2.5 & 3.2 & 3.0 & 2.5 & 3.5 \\
\hline
\end{tabular}

Sources: Burkinabe authorities; and IMF staff estimates and projections. 
Table 8. Burkina Faso: Selected Indicators on the Millennium Development Goals, 1990-2005

\begin{tabular}{|c|c|c|c|c|}
\hline & 1990 & 1995 & 2000 & 2005 \\
\hline Eradicate extreme poverty and hunger & \multicolumn{4}{|c|}{ (2015 target: halve 1990 US $\$ 1$ a day poverty and malnutrition rates) } \\
\hline Income share held by lowest $20 \%$ &.. & 5.1 & 5.9 & 6.9 \\
\hline Poverty gap at $\$ 1$ a day (PPP) (\%) &.. & 19.5 & 14.4 & 7.3 \\
\hline Poverty headcount ratio at $\$ 1$ a day (PPP) (\% of population) & .. & 51.4 & 44.9 & 27.2 \\
\hline Poverty headcount ratio at national poverty line (\% of population) &.. &.. & 54.6 & 46.4 \\
\hline Prevalence of undernourishment (\% of population) & 21 & 19 & .. & 15 \\
\hline Achieve universal primary education & \multicolumn{4}{|c|}{ (2015 target: net enrollment to 100$)$} \\
\hline Literacy rate, youth total (\% of people ages $15-24$ ) & .. &.. & .. & 31 \\
\hline Persistence to grade 5 , total ( $\%$ of cohort) & 70 &.. & 69 & 76 \\
\hline Primary completion rate, total ( $\%$ of relevant age group) & 20 & 20 & 25 & 31 \\
\hline School enrollment, primary (\% net) & 29 & .. & 36 & 45 \\
\hline Promote gender equality and empower women & \multicolumn{4}{|c|}{ (2015 target: education ratio 100$)$} \\
\hline Proportion of seats held by women in national parliament (\%) & .. & 4 & 8 & 12 \\
\hline Ratio of girls to boys in primary and secondary education (\%) & 61 & .. & 70 & 77 \\
\hline $\begin{array}{l}\text { Share of women employed in the nonagricultural sector ( } \% \text { of total nonagricultural } \\
\text { employment) }\end{array}$ & 12.5 & 13 & 13.9 & 14.6 \\
\hline Reduce child mortality & \multicolumn{4}{|c|}{ (2015 target: reduce 1990 under 5 mortality by two-thirds) } \\
\hline Immunization, measles ( $\%$ of children ages $12-23$ months) & 79 & 43 & 59 & 84 \\
\hline Mortality rate, infant (per 1,000 live births) & 113 & 107 & 100 & 96 \\
\hline Mortality rate, under-5 (per 1,000$)$ & 210 & 204 & 196 & 191 \\
\hline Improve maternal health & \multicolumn{4}{|c|}{ (2015 target: reduce 1990 maternal mortality by three-fourths) } \\
\hline Births attended by skilled health staff ( $\%$ of total) &.. & 42 & 31 & 38 \\
\hline Maternal mortality ratio (modeled estimate, per 100,000 live births) &.. & .. & 1000 & .. \\
\hline Combat HIVIAIDS, malaria, and other diseases & \multicolumn{4}{|c|}{ (2015 target: halt, and begin to reverse, AIDS, etc) } \\
\hline Contraceptive prevalence (\% of women ages $15-49)$ & & 25 & 12 & 14 \\
\hline Incidence of tuberculosis (per 100,000 people) & 158 & 155 & 182 & 223 \\
\hline Prevalence of HIV, female (\% ages 15-24) & .. & .. & .. & 1.4 \\
\hline Prevalence of HIV, total (\% of population ages $15-49$ ) &.. & .. & .. & 2 \\
\hline Tuberculosis cases detected under DOTS (\%) &.$\cdot$ & 11 & 17 & 18 \\
\hline CO2 emissions (metric tons per capita) & 0.1 & 0.1 & 0.1 & 0.1 \\
\hline Forest area ( $\%$ of land area) & 26 & .. & 25 & 25 \\
\hline GDP per unit of energy use (constant 2000 PPP \$ per kg of oil equivalent) & .. & .. & .. & .. \\
\hline Improved sanitation facilities (\% of population with access) & 7 & .. & .. & 13 \\
\hline Improved water source (\% of population with access) & 38 &.. & .. & 61 \\
\hline Nationally protected areas (\% of total land area) & .. & .. & .. & 15.4 \\
\hline Develop a global partnership for development & \multicolumn{4}{|c|}{ (2015 target: various) } \\
\hline Aid per capita (current US\$) & 38 & 50 & 30 & 50 \\
\hline Debt service (PPG and IMF only, \% of exports of G\&S, excl. workers' remittances) & 7.8 & 14.6 & 20.3 & 6.8 \\
\hline Internet users (per 1,000 people) & 0 & 0 & 1 & 5 \\
\hline Personal computers (per 1,000 people) & 0 & 0 & 1 & 2 \\
\hline Total debt service (\% of exports of goods, services and income) & 6.8 & 11.9 & 14.9 & .. \\
\hline Unemployment, youth female (\% of female labor force ages $15-24$ ) & .. & .. & .. & .. \\
\hline Unemployment, youth male (\% of male labor force ages $15-24$ ) &.. & .. & .. & .. \\
\hline Unemployment, youth total (\% of total labor force ages $15-24)$ &.. & .. & .. & .. \\
\hline \multicolumn{5}{|l|}{ Other } \\
\hline Fertility rate, total (births per woman) & 6.9 & 6.9 & 6.3 & 5.9 \\
\hline GNI per capita, Atlas method (current US\$) & 350 & 240 & 250 & 400 \\
\hline GNI, Atlas method (current US\$) (billions) & 2.9 & 2.4 & 2.8 & 5.2 \\
\hline Gross capital formation ( $\%$ of GDP) & 18.2 & 22.8 & 22.7 & 20.6 \\
\hline Life expectancy at birth, total (years) & 48 & 46 & 47 & 48 \\
\hline Literacy rate, adult total (\% of people ages 15 and above) & .. & .. & .. & 22 \\
\hline Population, total (millions) & 8.5 & 9.8 & 11.3 & 13.2 \\
\hline Trade (\% of GDP) & 35.6 & 39.5 & 34.4 & 30.6 \\
\hline
\end{tabular}

Source: World Development Indicators database, July 2007. 


\section{APPENDIX I. BURKInA FASO: DebT SUSTAInABILITy ANALYSIS (UPDATE)}

This appendix updates the joint debt sustainability analysis (DSA) from April 2007. ${ }^{14}$ Overall, the risk of debt distress has increased because of deterioration in the export outlook and some uncertainty as to whether Burkina Faso will be able to maintain its status as a strong performer. The upcoming joint DSA planned for 2008 will assess both aspects-based on additional data that will be available then. ${ }^{15}$

\section{The export outlook has worsened since the previous joint DSA mainly on} account of cotton. The harvest for the 2006/07 campaign was 15 percent lower than expected, and projections for the 2007/08 harvest had to be reduced by another 30 percent as a result of unfavorable weather conditions; the reduction in producer prices also contributed to the downward revision, but to a lesser extent. Assuming normal weather conditions for $2008 / 09$, cotton production is projected to rebound by 30 percent, but given the lower base, the long-run production outlook remains below its previous trajectory (Figure I.1, Panel 1). The export profile for non-cotton exports has been revised to incorporate an earlier-thanexpected startup of commercial gold mining operations, which offsets initially some of the decline in cotton production (Figure I.1, Panel 2). Overall, export projections have been revised downwards by approximately 12 percent in the long term (Figure I.1, Panel 3), and the exports-to-GDP share by about 1 percentage point (Figure I.1, Panel 4).

49. The fiscal stance, as measured by the overall balance excluding grants, has loosened somewhat, but external borrowing requirements are lower. Whereas the revenue path in terms of GDP has remained unchanged, expenditures over the medium term are higher on account of additional capital spending and a higher base in 2007

(Figure I.2, Panel 1). Nevertheless, external borrowing requirements in 2007 and 2008 are expected to decline considerably relative to previous projections because of higher grants and larger recourse to domestic financing (Figure I.2, Panel 2). Additional grant resources are available from the U.S. Millennium Challenge Corporation (MCC) and from the World Bank and the African Development Bank following Burkina Faso's classification as having a moderate risk of debt distress. Larger recourse to domestic financing is facilitated by the inflow of substantial privatization receipts in 2007.

\footnotetext{
${ }^{14}$ See IMF Country Report No. 07/153, May 9, 2007. The update has been shared with World Bank staff.

${ }^{15}$ Since domestic debt is small in Burkina Faso, this updates focuses on external public debt.
} 
Figure I.1. Burkina Faso: Recent Export Developments

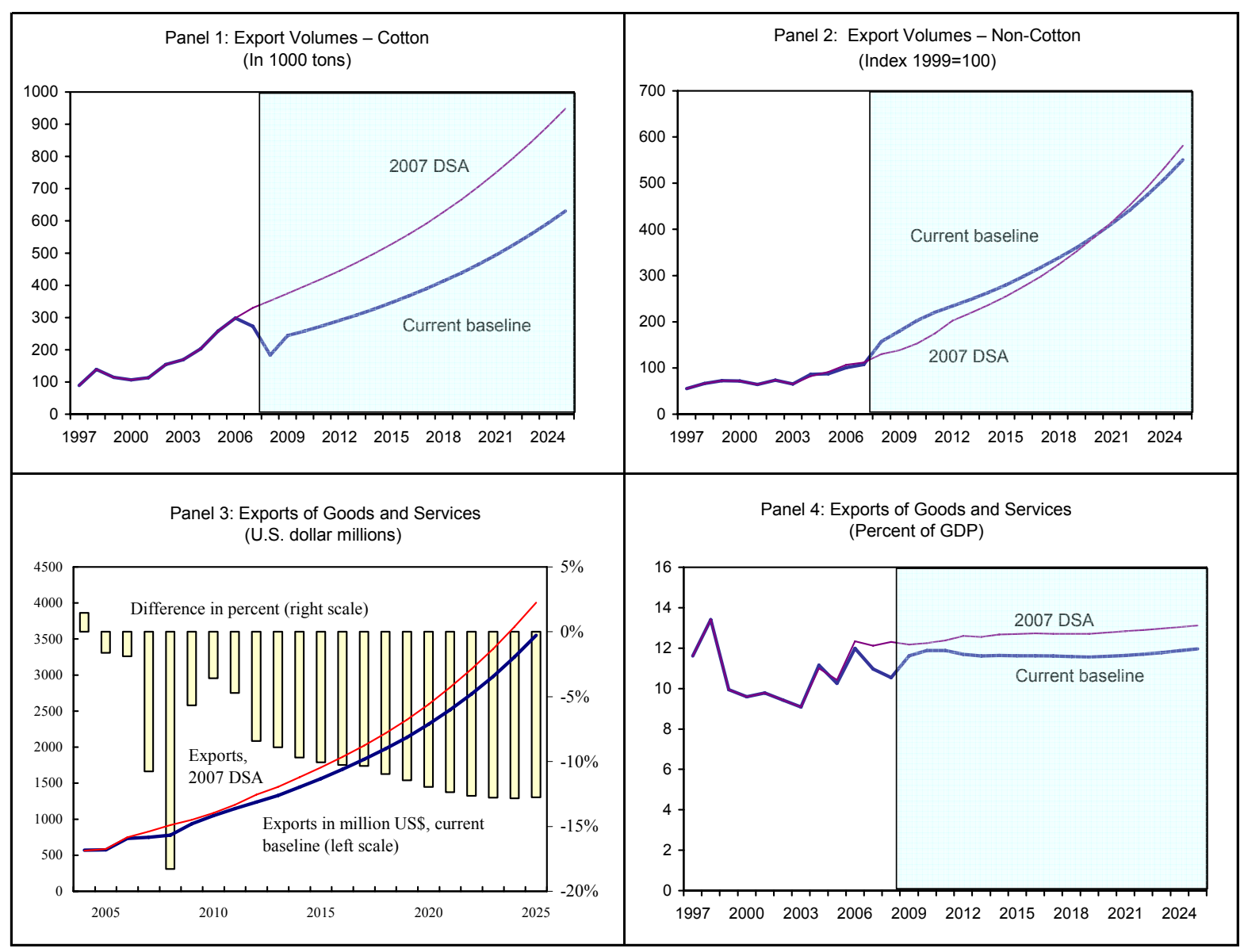

Sources: Burkinabè authorities; and IMF staff estimates.

50. On balance, risks to the debt sustainability outlook have increased. The reduction in external borrowing requirements has lowered the NPV of debt-to-exports ratio below its previous trajectory over the medium term, but in the long term the deterioration in the export outlook dominates, and the NPV of debt-to-exports ratio rises closer to its indicative threshold (Figure I.3, Panel 1). However, the baseline does not take into account grants from the World Bank and the African Development Bank that could result from future risk of debt distress ratings. ${ }^{16}$ If one were to assume that the moderate risk of debt distress ('yellow light') and the corresponding 50:50 mix of loans and grants were maintained for another five years, the increase in the NPV of debt-to-exports ratio would be considerably dampened (Figure I.3, Panel 2). That is, the likely support from these two institutions given Burkina Faso's risk of

\footnotetext{
${ }^{16}$ If a country is rated at a moderate risk of debt distress, the loan/grant allocation mechanism of these two institutions switches from 'green' to 'yellow', leading to a 50:50 disbursement mix of loans and grants. In case of a high risk of debt distress rating ('red light'), they will disburse 100 percent grants. However, apart from the current fiscal year, for which firm grant commitments have been made, baseline projections do not take this mechanism into account, because doing so would require forecasting future risk of debt distress ratings, and it would be impractical with respect to the allocation mechanisms of the World Bank and the African Development Bank, which require an analysis that abstracts from their endogenous response.
} 
debt distress rating will probably lead to a significantly more favorable trajectory for debt ratios than is projected under the baseline.

Figure I.2. Burkina Faso: Fiscal Stance

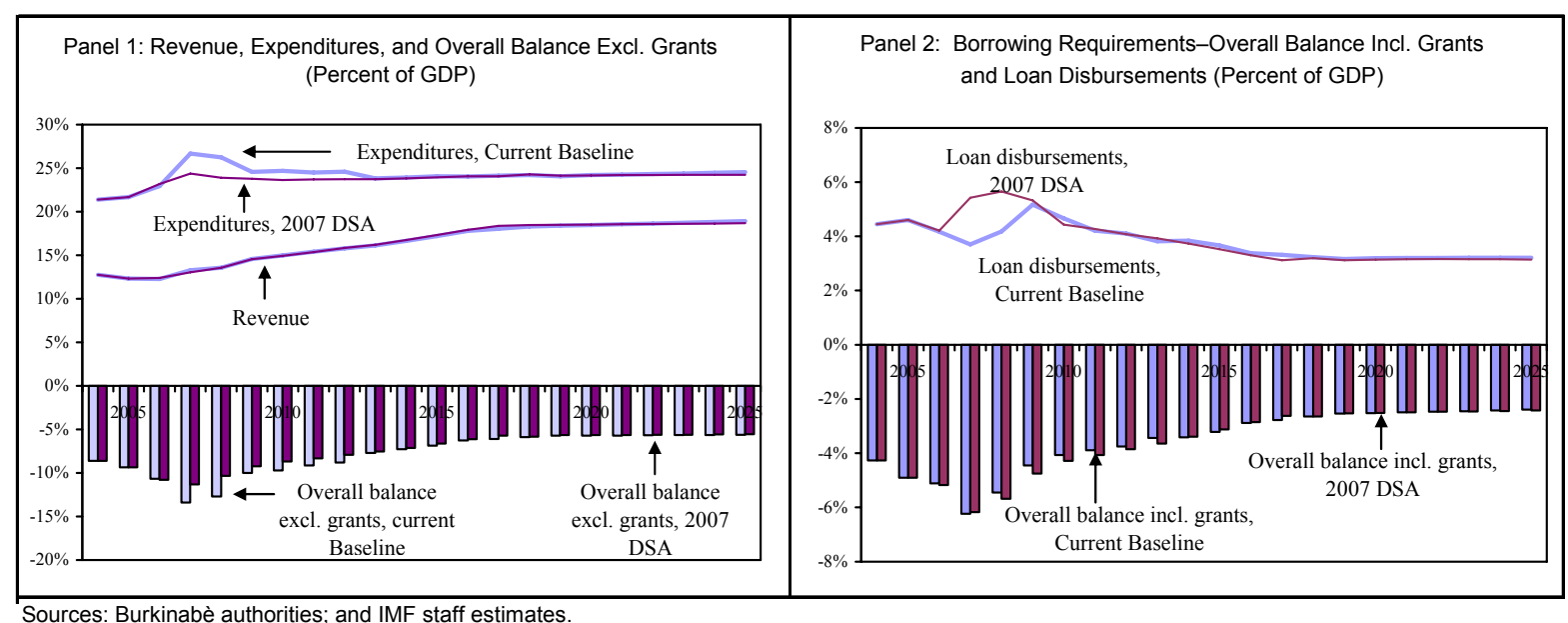

Figure I.3. Burkina Faso: Current Baseline and Yellow-Light Scenario

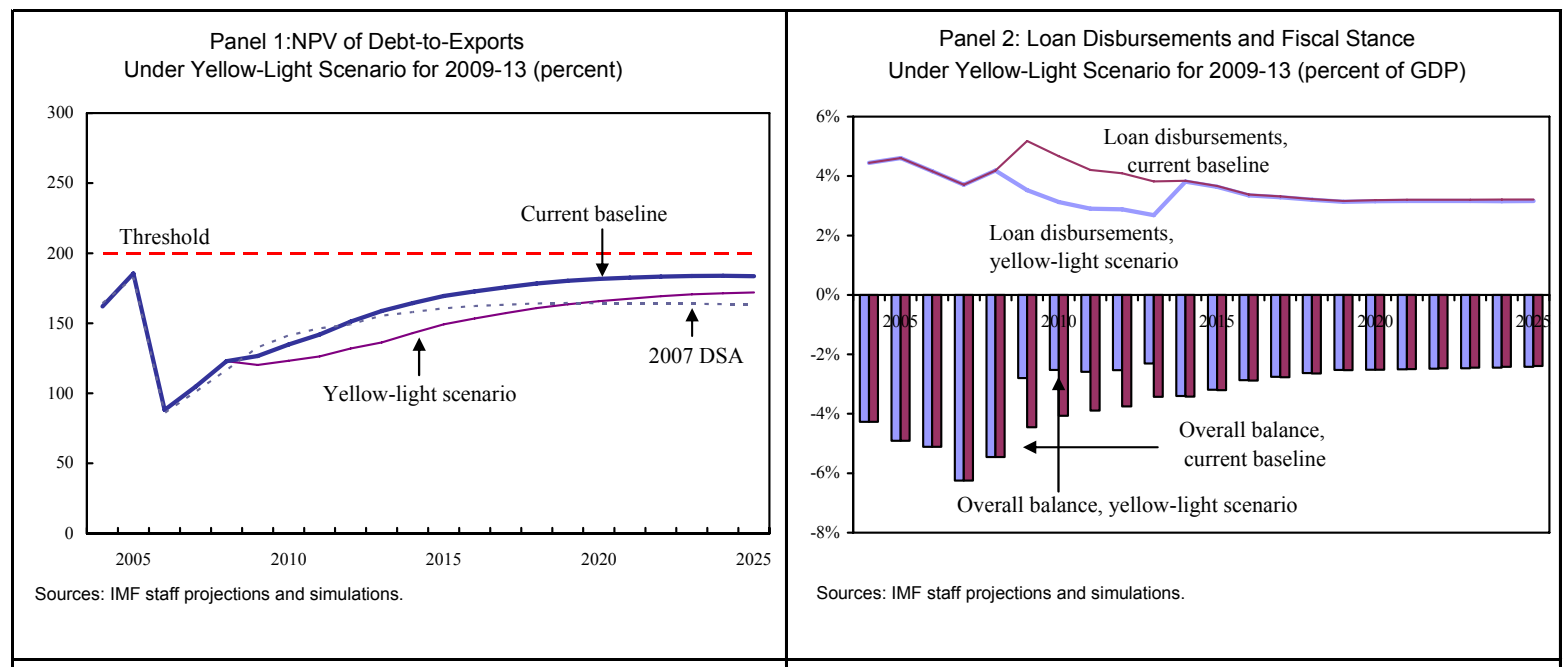

51. Another risk to the debt outlook relates to Burkina Faso's performance rating.

This is based on the World Bank's Country Policy and Institutional Assessment (CPIA). In the 2006 rating, which became available after the last joint DSA was finalized, Burkina Faso's score declined below the threshold for strong performers; in the absence of a strong improvement in the 2007 rating, it is likely that Burkina Faso could be reclassified as a medium performer, in which case lower indicative thresholds would apply. In the baseline projection, the NPV of debt-to-exports ratio threshold would be breached-all other debt indicators remain below their thresholds, including stress tests and historical scenarios- 
which could lead to a high risk of debt distress rating (Figure I.4, Panel 1). In this case, the World Bank and the African Development Bank would switch to a 'red light' in their loan/grant allocation mechanism, leading to 100 percent grant disbursements. If this 'redlight' status were to be maintained over 10 years, the trajectory for the NPV of debt-toexports ratio might be dampened enough to keep it below the 150 percent threshold (Figure I.4, Panels 1 and 2).

Figure I.4. Burkina Faso: Red-Light Scenario for 2009-18

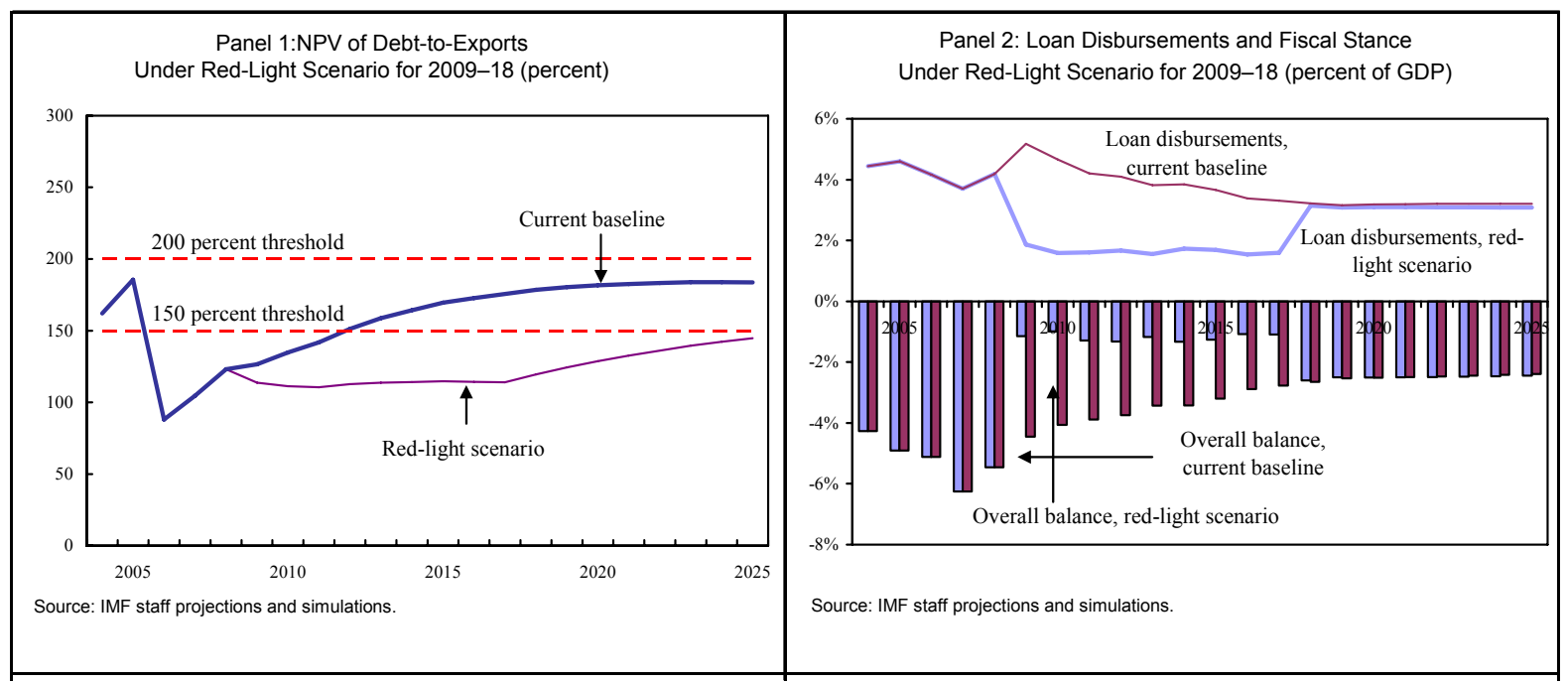


41

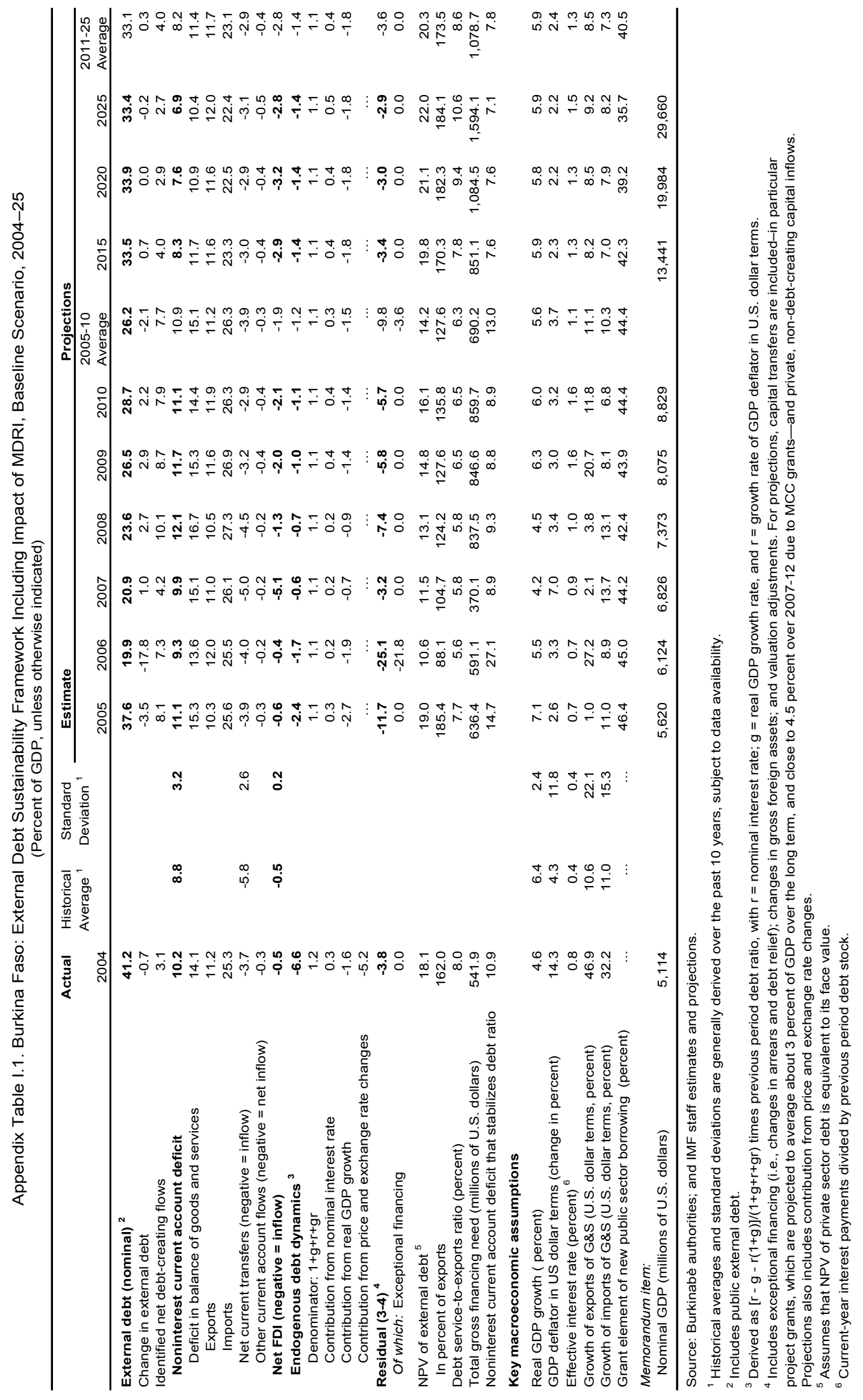


Appendix Table I.2. Burkina Faso: Sensitivity Analysis for Key Indicators of Public External Debt, 2005-25 (Percent)

\begin{tabular}{|c|c|c|c|c|c|c|c|c|}
\hline & \multicolumn{2}{|c|}{ Est. } & \multicolumn{6}{|c|}{ Projections } \\
\hline & 2005 & 2006 & 2007 & 2008 & 2009 & 2010 & 2015 & 2025 \\
\hline \multicolumn{9}{|l|}{ NPV of debt-to-GDP ratio } \\
\hline Baseline & 19.0 & 10.6 & 11.5 & 13.1 & 14.8 & 16.1 & 19.8 & 22.0 \\
\hline \multicolumn{9}{|l|}{ A. Alternative Scenarios } \\
\hline A1. Key variables at their historical averages in $2007-25^{1}$ & 19.0 & 10.6 & 13.7 & 13.5 & 14.2 & 15.0 & 20.9 & 36.7 \\
\hline A2. New public sector loans on less favorable terms in $2007-25^{2}$ & 19.0 & 10.6 & 13.5 & 16.2 & 19.1 & 21.4 & 28.7 & 34.6 \\
\hline \multicolumn{9}{|l|}{ B. Bound Tests } \\
\hline B1. Real GDP growth at historical average minus one standard deviation in 2007-08 & 19.0 & 10.6 & 11.5 & 13.2 & 14.9 & 16.3 & 19.9 & 22.2 \\
\hline B2. Export value growth at historical average minus one standard deviation in $2007-08^{3}$ & 19.0 & 10.6 & 12.4 & 13.9 & 15.6 & 16.9 & 20.3 & 22.2 \\
\hline B3. U.S. dollar GDP deflator at historical average minus one standard deviation in 2007-08 & 19.0 & 10.6 & 13.3 & 16.9 & 19.1 & 20.8 & 25.6 & 28.5 \\
\hline B4. Net non-debt-creating flows at historical average minus one standard deviation in 2007-08 ${ }^{4}$ & 19.0 & 10.6 & 15.1 & 17.7 & 19.2 & 20.3 & 22.8 & 23.1 \\
\hline B5. Combination of B1-B4 using one-half standard deviation shocks & 19.0 & 10.6 & 12.8 & 15.0 & 16.9 & 18.3 & 22.2 & 24.4 \\
\hline B6. One-time 30 percent nominal depreciation relative to the baseline in $2007^{5}$ & 19.0 & 10.6 & 16.0 & 18.2 & 20.6 & 22.4 & 27.5 & 30.6 \\
\hline \multicolumn{9}{|l|}{ NPV of debt-to-exports ratio } \\
\hline Baseline & 185.4 & 88.1 & 104.7 & 124.2 & 127.6 & 135.8 & 170.3 & 184.1 \\
\hline \multicolumn{9}{|l|}{ A. Alternative Scenarios } \\
\hline A1. Key variables at their historical averages in $2007-25^{1}$ & 185.4 & 88.1 & 124.5 & 127.6 & 122.4 & 126.5 & 180.2 & 306.2 \\
\hline A2. New public sector loans on less favorable terms in $2007-25^{2}$ & 185.4 & 88.1 & 123.2 & 153.3 & 164.1 & 180.0 & 247.1 & 288.9 \\
\hline \multicolumn{9}{|l|}{ B. Bound Tests } \\
\hline B1. Real GDP growth at historical average minus one standard deviation in 2007-08 & 185.4 & 88.1 & 104.7 & 124.2 & 127.6 & 135.8 & 170.3 & 184.1 \\
\hline B2. Export value growth at historical average minus one standard deviation in $2007-08^{3}$ & 185.4 & 88.1 & 129.9 & 179.0 & 182.1 & 192.5 & 237.0 & 251.6 \\
\hline B3. U.S. dollar GDP deflator at historical average minus one standard deviation in 2007-08 & 185.4 & 88.1 & 104.7 & 124.2 & 127.6 & 135.8 & 170.3 & 184.1 \\
\hline B4. Net non-debt-creating flows at historical average minus one standard deviation in $2007-08^{4}$ & 185.4 & 88.1 & 137.8 & 167.5 & 164.9 & 170.4 & 196.2 & 193.1 \\
\hline B5. Combination of B1-B4 using one-half standard deviation shocks & 185.4 & 88.1 & 112.0 & 138.7 & 141.5 & 149.9 & 185.7 & 198.2 \\
\hline B6. One-time 30 percent nominal depreciation relative to the baseline in $2007^{5}$ & 185.4 & 88.1 & 104.7 & 124.2 & 127.6 & 135.8 & 170.3 & 184.1 \\
\hline \multicolumn{9}{|l|}{ Debt service-to-exports ratio } \\
\hline Baseline & 7.7 & 5.6 & 5.8 & 5.8 & 6.5 & 6.5 & 7.8 & 10.6 \\
\hline \multicolumn{9}{|l|}{ A. Alternative Scenarios } \\
\hline \multicolumn{9}{|l|}{ B. Bound Tests } \\
\hline B1. Real GDP growth at historical average minus one standard deviation in 2007-08 & 7.7 & 5.6 & 5.8 & 5.8 & 6.5 & 6.5 & 7.8 & 10.6 \\
\hline B2. Export value growth at historical average minus one standard deviation in $2007-08^{3}$ & 7.7 & 5.6 & 6.7 & 8.1 & 9.1 & 9.0 & 11.0 & 14.5 \\
\hline B3. U.S. dollar GDP deflator at historical average minus one standard deviation in 2007-08 & 7.7 & 5.6 & 5.8 & 5.8 & 6.5 & 6.5 & 7.8 & 10.6 \\
\hline B4. Net non-debt-creating flows at historical average minus one standard deviation in 2007-08 ${ }^{4}$ & 7.7 & 5.6 & 5.8 & 6.6 & 7.4 & 7.3 & 9.8 & 11.5 \\
\hline B5. Combination of B1-B4 using one-half standard deviation shocks & 7.7 & 5.6 & 5.9 & 6.3 & 7.1 & 7.1 & 8.6 & 11.4 \\
\hline B6. One-time 30 percent nominal depreciation relative to the baseline in $2007^{5}$ & 7.7 & 5.6 & 5.8 & 5.8 & 6.5 & 6.5 & 7.8 & 10.6 \\
\hline \multicolumn{9}{|l|}{ Memorandum item: } \\
\hline Grant element assumed on residual financing (i.e., financing required above baseline) ${ }^{6}$ & 40.7 & 40.7 & 40.7 & 40.7 & 40.7 & 40.7 & 40.7 & 40.7 \\
\hline
\end{tabular}

Source: IMF staff estimates and projections.

${ }^{1}$ Variables include real GDP growth, growth of GDP deflator ( U.S. dollar terms), non-interest current account in percent of GDP, and non-debt-creating flows.

${ }^{2}$ Assumes that the interest rate on new borrowing is 2 percentage points higher than in the baseline, while grace and maturity periods are the same.

${ }^{3}$ Export values are assumed to remain permanently at the lower level, but the current account as a share of GDP is assumed to return to its baseline level after the shock (implicitly assuming an offsetting adjustment in import levels).

${ }^{4}$ Includes official and private transfers and FDI.

${ }^{5}$ Depreciation is defined as percentage decline in dollar/local currency rate, such that it never exceeds 100 percent.

${ }^{6}$ Applies to all stress scenarios except for A2 (less favorable financing) in which the terms on all new financing are as specified in footnote 2. 
Figure I.5. Burkina Faso: Indicators of Public External Debt Under Alternative Scenarios, 2005-25

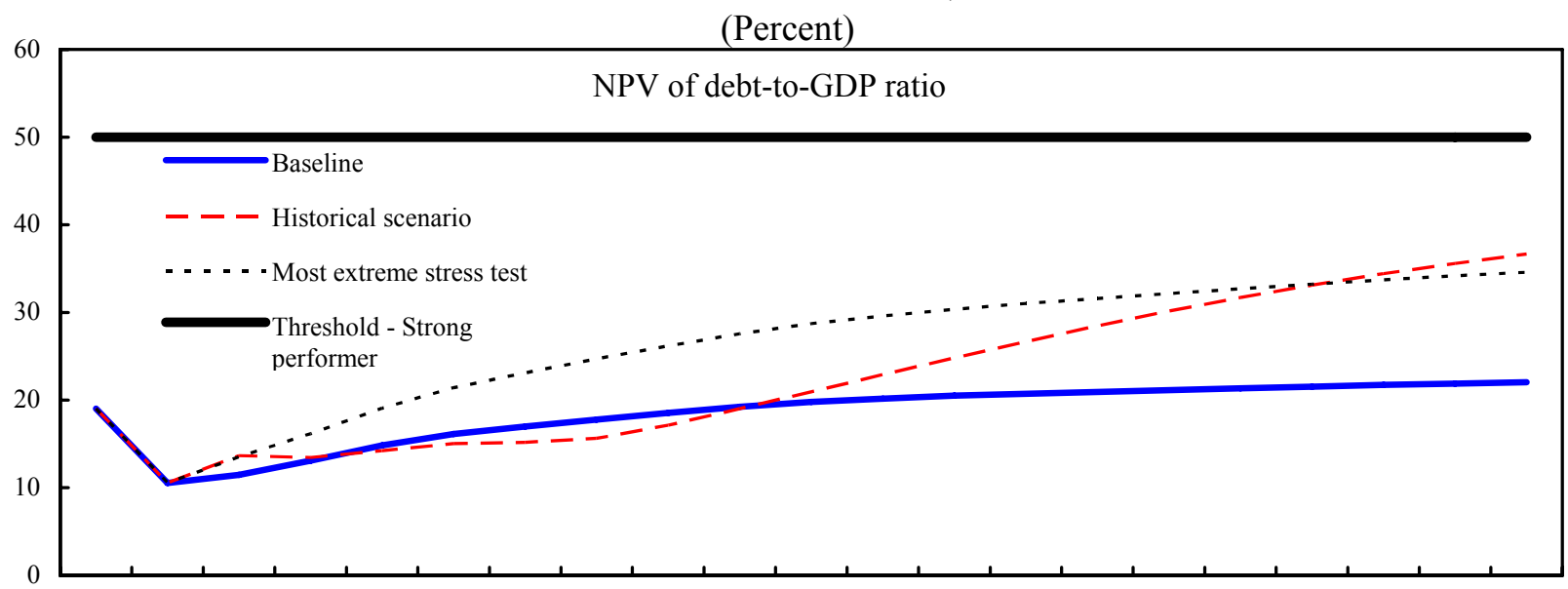

200520062007200820092010201120122013201420152016201720182019202020212022202320242025
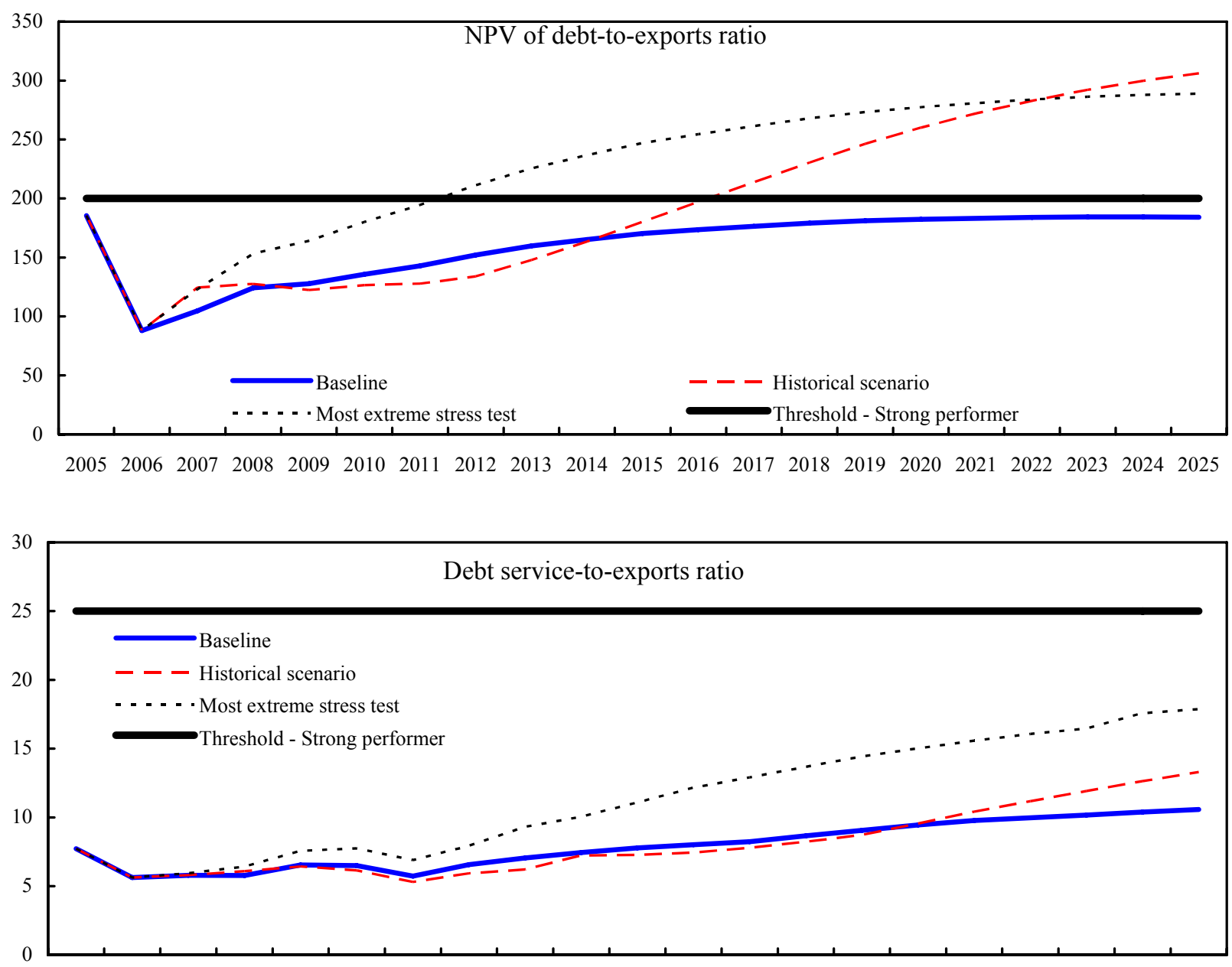

200520062007200820092010201120122013201420152016201720182019202020212022202320242025

Source: IMF staff projections and simulations. 


\section{APPENDIX II. BURKINA FASO: LETTER OF INTENT}

Translated from French

Ouagadougou, December 20, 2007

Mr. Dominique Strauss-Kahn

Managing Director

International Monetary Fund

$70019^{\text {th }}$ Street NW

Washington, DC 20431

USA

Mr. Strauss-Kahn:

The government of Burkina Faso has successfully implemented the measures contained in its economic program carried out with the support of the International Monetary Fund through its Poverty Reduction and Growth Facility (PRGF). The program, approved by the IMF Board on April 23, 2007 for an amount equivalent to SDR 6.02 million (10 percent of quota), runs through April 2010.

The attached memorandum of economic and financial policies (MEFP) supplements the one attached to my letter to you dated April 11, 2007. The MEFP attached to that letter established quantitative performance criteria (for end-June 2007) and structural performance criteria (for end-June 2007) for the completion of the first review under the PRGF arrangement.

The quantitative performance criteria for the completion of the first review under the PRGF arrangement were observed. However, we are requesting a waiver of applicability for the two structural performance criteria. For one of them the related measures were put into place, but with a delay, and for the second, the measures will be in place starting in February 2008. On the basis of our overall performance, and on the strength of the policies set forth in the attached memorandum, we request that the IMF complete the first review under the PRGF and disburse the second loan in the amount of SDR 3.51 million.

The cotton crisis and deterioration in Burkina Faso's terms of trade caused by higher world oil prices has considerably weakened our external position. The government is determined to forcefully address these challenges and, to facilitate the adjustment while addressing our additional balance of payments needs, requests an augmentation of access under the PRGF arrangement in an amount equivalent to SDR 9.03 million (15 percent of quota). 
The government believes that the policies set forth in the attached MEFP will enable it to meet its program objectives, but is ready to take any other measures that might be necessary to this end. Burkina Faso will consult with the Fund on the adoption of any measures that may be appropriate, and in advance of revisions to the policies contained in the attached Memorandum of Economic and Financial Policies (MEFP), in accordance with the Fund's policies on such consultation. The second review under the PRGF arrangement is expected to be completed no later than end-July 2008 and the third review by endJanuary 2009.

The government intends to make the contents of this letter and the attached MEFP and Technical Memorandum of Understanding available to the public. Therefore, it authorizes the IMF to post these documents on the IMF website once the Executive Board concludes the review.

Sincerely yours,

$$
/ \mathrm{s} /
$$

Jean-Baptiste M. P. Compaoré

Minister of Economy and Finance

Commander of the National Order

Attachments: Memorandum of Economic and Financial Policies

Technical Memorandum of Understanding 


\section{APPENDIX II. ATTACHMENT I. BURKINA FASO: MEMORANDUM OF ECONOMIC AND Financial Policies of the Government for 2007-08}

Translated from French

\section{INTRODUCTION}

1. This memorandum updates Burkina Faso's economic and financial program under the three-year Poverty Reduction and Growth Facility (PRGF) arrangement with the IMF. The program, which was approved by the IMF's Board of Executive Directors on April 23, 2007, aims at consolidating macroeconomic stability and fostering conditions that can sustain high economic growth and reduce poverty. ${ }^{17}$ This memorandum summarizes recent economic developments, reviews performance under the PRGF-supported program, and updates the government's strategy for pursuing its financial and economic policies.

2. Burkina Faso's macroeconomic performance in $\mathbf{2 0 0 6}$ was good. Economic growth was a resilient $5 \frac{1}{2}$, despite low international cotton prices and the strength of the euro, to which the CFA franc is pegged. Inflation fell below the WAEMU convergence criterion of 3 percent. Exports grew strongly, partly because the fall in world cotton prices was not fully passed on to farmers. Imports were higher than expected because of an upward revision in historical petrol imports, leading to higher than envisioned external current account deficits. Fiscal policy loosened as planned, as reflected in the fiscal balance, excluding grants. Revenue collections fell short, but increases in grants partly offset the difference. An adjustment in expenditures resulted in a better-than-expected deficit, including grants. Debt sustainability benefited from MDRI relief, which cut the external debt stock in half.

3. Limited pass-through of lower world cotton prices to producers caused sizable financial losses among ginning companies. As a result, SOFITEX — the largest ginning company, which is partly government owned - has been recapitalized to restore its financial health (see below). The recent adoption of a new producer price mechanism linked to changes in world prices is crucial to getting ginning companies back on sustainable footing, but adverse weather conditions, lower prices, and other factors have hurt cotton output.

4. We have made substantial progress in reforming revenue administration and public financial management, but a large reform agenda must still be accomplished. In the past two years, we computerized tax and customs administration and set up joint brigades to combat fraud. The former Ministry of Finance and Budget and Ministry of Economy and Development were merged into one, improving policy coordination. There has also been

\footnotetext{
${ }^{17}$ The program document was published as IMF country report CR07/153 (04/11/2007) on the IMF website (www.imf.org).
} 
progress in computerizing the expenditure system. However, perhaps because of inappropriate prioritization of revenue administration reforms, revenue fell short of expectations and the revenue ratio remains low by both international standards and the WAEMU criteria. Further progress is also needed in other areas.

\section{MACROECONOMic FRAMEWORK FOR 2007 AND PROGRAM IMPLEMENTATION THROUGH SEPTEMBER}

\section{A. Recent Economic Developments and 2007 Macroeconomic Framework}

\section{Recent economic activity is still robust, despite signs of slowing related to} difficulties in the cotton sector. Fiscal stimulus fueled economic activity. In the first half of 2007 , total fiscal expenditures increased by over 30 percent year-on-year. Inflation has declined steadily since the second half of 2006 and turned negative in recent months, as food prices have dropped, with the help of good grain harvests in both 2005 and 2006. Meanwhile, nonfood inflation remains moderate, even though the increase in world oil prices was fully passed through to domestic petrol prices.

6. An abrupt decline in cotton output will reduce GDP growth in 2007. The $2007 / 08$ output is expected to fall by a third from the already reduced 2006/07 result, from 657,000 tons to 435,000 . The decline primarily stems from adverse climate conditions (late rainfall) but also reflects the decline in the producer floor price, which is 12 percent lower than a year ago, delayed payments from the last campaign, and the late announcement of the producer floor price. Given the late start of this season's rains, some producers decided to stop or reduce cotton production and will instead produce maize and, to a lesser extent, sorghum and millet. These crops will mostly be grown for the farmers' own consumption and thus will not enter the formal economy. Bad weather has also reduced expected maize output, and vulnerable farmers may need support (see below). Given these developments, projected growth for 2007 was reduced to 41/4 percent; inflation is expected to be slightly below zero.

\section{B. Program Implementation and Policies for the Rest of 2007}

7. Some fiscal targets for June were narrowly missed. Government revenues at the end of June fell marginally short by CFAF 2 billion (about 1 percent), while grants exceeded projections by CFAF 8 billion. Expenditures on a commitment basis were higher than expected for goods and services because of one-off expenditures (utility payments, salaries (stemming from a 2006 agreement), and higher-than-expected expenditures resulting from the decentralization program), larger externally financed capital spending, and higher-thanprojected expenditure execution rates through June. However, on a payment-order basis, expenditures were lower and end-June performance criterion on the fiscal deficit, including grants (on a payments-order basis), was met. The indicative floor on social expenditures was missed by less than 1 percent because of strong spending pressures related to the recapitalization of SOFITEX, where the amount turned out larger than anticipated - some of the budgetary support for the sector was even moved to 2008. 
8. The deficit target for 2007 will be observed despite lower projected revenues. Because of lower economic growth and inflation, the nominal year-end revenue target was reduced by CFAF 10 billion; in percent of GDP, the revised revenue target nevertheless represents an increase by one percentage point relative to 2006, exceeding the programmed increase by 0.2 percentage points. To reach the target, we intend to complete the computerization of the large taxpayer office in the tax administration, devote more resources to audit and collection enforcement, and make better use of ASYCUDA and the import valuation database in customs administration. Grants are now projected to be about CFAF 60 billion higher than programmed, mainly because grant-financed projects were implemented faster than expected and some additional budget support grants. Thus, the yearend performance criterion for the deficit, including grants, is projected to be met despite higher expenditures. Most additional spending is foreign-financed capital spending and moderately higher current expenditures, in particular utilities and wages. The projections also include an additional CFAF 8 billion to complete SOFITEX' recapitalization and CFAF 4 billion for the payment of VAT refund arrears.

9. Parts of the structural reform agenda were delayed. We adopted a new producer price mechanism for cotton in May, thus meeting the related structural benchmark. We will continue to implement the automatic adjustment mechanism for petroleum products in 2008 despite high international oil prices and delayed implementation in July-November 2007. SINTAX, the tax administration computer system, was modified so that late filers and nonfilers will be automatically notified starting in July (continuous structural performance criterion). However, because of the delayed transmission of the filing information of taxpayers that do not file their declarations with the large taxpayer office (LTO) in Ouagadougou but with local offices, not all late filers received their notification letter on time. Between now and the completion of the interconnection of the computer system, all large taxpayer declarations received by local offices will be faxed to the LTO so computer records are complete and late filers can be notified automatically on time. We are currently reviewing the need for further organizational changes, and the new head of computerization will work to assure the implementation of the notification measure starting after January 31, 2008. Another structural benchmark that went unmet was the prompt payment of VAT refunds. Although a circular was issued that outlined procedures to ensure VAT refunds are paid on time (within 90 days after the refund is requested), communications problems between the agencies involved caused initial delays. As of November 15, 2007, all verified and unverified requests more than 90 days old were paid.

10. We intend to eliminate the delays in customs administration. The single customs declaration form was in place in 14 of the 15 computerized customs offices by end-June (missed structural performance criterion). The Bingo office will use the form after it relocates its offices. There were also delays in preparing regulations for noncomputerized offices, which are responsible for less than 6 percent of customs revenues. However, as of November 22, 2007, all customs offices are using the single customs declaration form. We have put in place a computerized customs-specific valuation database in all the computerized 
offices (end-September structural benchmark) for use in the customs process. We did not meet the end-September structural benchmark for using the remote access and selectivity modules of the computerized customs system ASYCUDA in Ouagadougou. However, remote access tests for the Ouagadougou rail office with seven brokers were successful. We will use the remote access and selectivity modules in all computerized offices by December 31, 2007.

\section{POLICIES FOR 2008}

\section{The cotton shock, which could be in part permanent, has hurt exports and debt} sustainability; this requires policies to reduce debt and improve competitiveness. Cotton exports in 2008 are now expected to be CFAF 44 billion lower than previously projected, and represent 37 percent of exports, from 45 percent previously. The fall in cotton exports is partly offset by the start of production in one major gold mine in 2007 and another two in 2008, which should significantly boost gold production and exports. Though we expect cotton production to rebound from 435,000 tons to around 580,000 tons in 2008/09, preliminary results indicate that the baseline path for the net present value (NPV) of the debtto-exports ratio will increase and almost reach the threshold under the debt sustainability (DSA) framework. Thus, debt distress risk has clearly increased and we are adjusting our policies accordingly. Over time, the most important way to improve our international competitiveness will be structural reforms, but reducing the budget deficit to levels that will stabilize our NPV of debt-to-GDP ratio at low levels is also necessary. A medium-term fiscal adjustment will also raise government savings and thus help reduce the current account deficit and prevent future losses of international reserves. The adjustment should be supported by the estimated $\$ 500$ million we expect to receive over the next five years from the U.S. Millennium Challenge Account; this increases our capacity to undertake additional capital spending, while reducing the overall fiscal deficit.

\section{A. Fiscal Policy}

\section{We will reduce the fiscal deficit for $\mathbf{2 0 0 8}$ to reflect the increased risk, but also} need to smooth the impact of the cotton shock. After the last joint Bank-Fund DSA, which changed the risk of debt distress from "low" to "moderate," the World Bank and the African Development Bank made half their financing to Burkina Faso grants. Normally, such an increase would be used to substantially lower the deficit from the 5.7 percent of GDP originally envisioned for 2008; but the cotton crisis and damages from the 2007 floods require social spending, and lower economic growth will have a negative impact on tax revenues of about CFAF 10 billion ( 0.3 percent of GDP). Adjusting for this revenue shortfall would reduce economic growth and would require large spending cuts, which could jeopardize progress toward reaching the Millennium Development Goals. Weighing these factors, we intend to aim at a deficit, including grants (on a commitment basis), of CFAF 192 billion (5.4 percent of GDP) to mitigate the negative impact of the shock on the economy. 


\section{Revenue policy is aimed at boosting competitiveness while improving tax}

administration. We have decided to lower the corporate income tax from 35 to 30 percent for 2008, which should reduce revenues by CFAF 10 billion. We believe that this is necessary to increase private sector investment and help Burkina Faso compete with its neighbors. We also think it will help boost revenues over time as economic growth accelerates and tax evasion decreases. There is also a very small loss in customs revenues expected after the WAEMU-ECOWAS free trade agreements are implemented. Despite these revenue reducing measures, we will be able to increase the revenue-to-GDP ratio by 0.2 percentage points in 2008 through our ambitious revenue administration reform, which will require steadfast application of modern revenue administration principles (see below).

14. We must prioritize expenditures given our limited resources. In 2008, we will

expand spending in the health and education sectors by expanding coverage in rural areas and providing free textbooks. We intend to increase social expenditures by CFAF 10 billion, more than the increase in current expenditures. Thus, we will keep firm control on current expenditures to allow for greater infrastructure spending. Additional funds for infrastructure will also be available because the 2008 budget does not require further funds for the completion of the SOFITEX recapitalization, which had a cost of CFAF 34 billion in 2007. Also, in 2008, we expect to receive about CFAF 24 billion funding through the U.S. Millennium Challenge Account. Thus, we still expect to be able to increase capital spending by CFAF 17 billion from 2007. We intend to work with the World Bank to make our overall spending more efficient, including through public expenditure reviews and analyses of capital projects.

\section{B. Cotton Sector Reform}

15. Cotton sector reform is progressing. We have already contributed 75 percent of the required recapitalization of SOFITEX and expect to complete it by the end of 2007 for a combined total of CFAF 34 billion paid by the government. We are working closely with the World Bank and other donors on the restructuring strategy for SOFITEX, and intend to finalize a government decision on its future liberalization by end-December (structural benchmark). We are also working on a strategy to restore the long-term viability of the cotton sector and to reduce government involvement in ginning over time, which is expected to be ready by mid-2008. The creation of a price smoothing fund (fonds de lissage) will be finalized by early 2008 with inputs and financial resources from the French Development Agency. We continue to work with cotton sector stakeholders to further improve the operation rules of the fund to ensure it is self-financing under most imaginable scenarios. Moreover, we will ensure that the finances of the fund are fully transparent. Finally, together with the World Bank, we are studying ways to address the impact of the cotton crisis in cotton-growing areas.

\section{Fiscal Structural Reform}

16. The structural agenda for $\mathbf{2 0 0 8}$ will focus on measures to mobilize more revenue and reinforce PFM. The recommendations of the Fund technical assistance missions have 
been useful for prioritizing our reform agenda in both areas. In the area of tax reform, we are on track to submit the unified tax code to parliament by end-December 2007 (structural benchmark). We now expect the tax policy reform strategy to be approved by cabinet by endApril 2008 (structural benchmark). The thrust of the strategy will be to broaden the tax base for the major taxes, eliminate nuisance taxes, and simplify the system for the taxpayer and tax administration. To meet our ambitious revenue targets for 2009 and beyond, we will submit draft tax policy reform legislation to parliament by end-December 2008 (structural benchmark). We are considering setting up a technical group to work on revenues within the framework of our Strategy for the Strengthening of Public Finances (SRPF) to help move this process forward.

\section{Measures to reform revenue administration will focus on the large taxpayer}

office (LTO). The establishment of the LTO has been a major milestone in tax administration reform. The minister of finance has approved the tax administration reform strategy that received inputs from Fund technical assistance. The strategy places most of its emphasis on ensuring that the LTO has the resources and strategic orientation to implement reforms. We will attempt to bring the nonfiler rate for large taxpayers to below 5 percent, from 12 percent in early 2007. Also, we intend to reduce the rate of VAT declarations with a zero or negative tax liability from its current level of 49 percent to less than 20 percent through issue-oriented audits. At the same time, we will ensure verified VAT refund requests are paid promptly and have allocated CFAF 6 billion in the budget to do so. Productivity gains will be reaped from computerization only after all software modules are integrated into the work flow. Given the limited resources for tax administration reform, we are scaling back our plans to decentralize the tax administration and are limiting the resources available to develop the cadastre system, two longer-term reform objectives. We will issue regulations to categorize taxpayers using turnover as the only criterion (i.e., large, medium, and small) with the objective of creating a group of about 500 large and 1,500 medium taxpayers, who would be subject to the regular tax system. By contrast, small taxpayers should be subject to simplified taxation instead of VAT. Implementation of these regulations would constitute a structural benchmark for end-June, 2008. We will also eliminate withholding for large taxpayers and simplify them for medium taxpayers starting in July 2008.

\section{Customs administration reform will concentrate on reducing the direct contact} between customs officials and traders to support the fight against fraud. The ASYCUDA system is designed to reduce this contact, which can easily be compromised, but ASYCUDA is not yet applied systematically by the customs administration. To ensure its use, we will design our selectivity system to assign at least 50 percent of customs declarations to the green and blue channels and will ensure that the cases where the ASYCUDA choice is not adhered to does not exceed 10 percent (structural benchmark end-September 2008). We intend to raise the ratio of declaration assigned to the green and blue channels over time by improving the risk assessment capabilities of the selectivity module. To this end, we will interface the customs valuations database with the ASYCUDA system to improve the valuation aspect of ASYCUDA by end-March 2008. The valuation 
data would be used both for customs duty calculation and as an input for the risk assessment in the selectivity module.

19. PFM measures will be directed to improving budget execution and preparation, and tracking spending. We are undertaking a study to expedite the processing of payments and eliminate redundancies of controls, which should be finalized by end-September 2008 . This will form the basis for an action plan to be implemented over 2008 and 2009 (structural benchmark, end-December 2008). To improve the scope and effectiveness of ex-post controls, we are in the process of fundamentally reforming the existing control framework to rationalize it and make it more effective. The draft laws that are being finalized seek to bring together under a single authority the tasks now accomplished by three separate bodies (the General Inspectorate of the State (Inspection générale de l'État), the High Authority for the Coordination of the Fight Against Corruption (Haute autorite de coordination de la lutte contre la corruption), and the National Commission for the Fight Against Fraud (Commission nationale de la lutte contre la fraude), and extending its jurisdiction to monitoring implementation of the recommendations of inspection missions and to judicial proceedings. Thus, we will study ways to scale up audit activities of this new institution during 2008, and provide it with the corresponding resources in the 2009 budget. We will also develop an action plan for scaled-up audit activities by the new institution by December 2008. To enhance the transparency and the deterrent effect of ex-post controls, we will propose by December 2008 modalities for the publication of audit reports and their recommendations, and the systematic follow up on the recommendations made by these offices. We also plan to increase the reliability of revenue forecasts for budget preparation. This will help improve budget execution by ensuring availability of resources. This concern will be addressed by the technical groups of the steering committee beginning with the 2009 budget process.

20. Tracking expenditures more closely is a priority. We have worked to develop a comprehensive system for tracking foreign-financed expenditures (end-December 2007 structural benchmark). The technical development work on the first module, which helps track the mobilization of funds, is expected to be completed before year-end. However, the need for numerous interfaces with other software systems and the overall complexity of the project have delayed the full implementation of all six modules until 2009 at the earliest. We are also working on establishing the interface between the integrated system for the management of wages and salaries (SIGASPE) and the software for general expenditure tracking (CID), with work expected to be completed by December 2008. To improve tracking of poverty-reducing expenditures, we will launch a pilot project applying the functional classification of GFSM 2001 to poverty-reducing expenditure tracking, which is expected to be operational by end-June 2008 (structural benchmark).

21. We are taking measures to improve internal and external expenditure controls. We recently completed the domestic debt audit, which started in 2004 with support from the Swiss Agency for Development and Cooperation as part of the previous PRGF program. The comprehensive inventory shows claims from various government suppliers amounting to 
about CFAF 78 billion at December 31, 2006. CFAF 50 billion of these obligations have already been examined, and those recognized have been paid, including the regularization of salary advancements (CFAF 18 billion). Of the CFAF 28 billion claims still under investigation in August 2007, some CFAF 15.4 billion relate to benefit claims on social security agencies (CARFO and CNSS), which will be dealt with according to the conventions relating to these organizations. An amount of CFAF 10.8 billion are contributions to international organizations, which will be analyzed case by case. A detailed report was submitted to the Cabinet to elicit instructions on the treatment of these claims, after verification, and on measures to be implemented to prevent similar situations in the future. One of the objectives of such audits, which are conducted periodically, is to ensure that all government institutions abide by public expenditure processes as prescribed by the instruments in force, and to remind them, if need be, about the obligations of financial controllers. To prevent such obligations from recurring, we intend to have regular meetings between the budget department and the financial controllers of the line ministries, and each party will have to adhere to the requirements of the budget law. In addition, we are considering ways to better define the profile of financial controllers and the organizational structures they oversee to achieve a better budget execution. We also discovered that an oversight in April 2007 led CFAF 3.3 billion to be paid to Libya, counter to the comparability-of-treatment clause under the Paris Club agreements, but no further payments will be made.

\section{Other Structural Reforms}

\section{As noted in the government's previous letter of intent, we will continue to} improve the business environment by combating corruption, streamlining procedures and the licensing of businesses, and enhancing labor market flexibility. Through our work with the International Finance Corporation (IFC), we are continuing to improve the business climate, especially in the area of access to credit. Significant progress was made in 2007, reflected in Burkina Faso's rating in IFC's latest Doing Business report: we introduced specialized commercial chambers, reduced judgment enforcement registration tax from 4 percent to 2 percent, reduced the property transfer and registration fees, and reduced the time to register a company to 23 days. Regarding the labor market, we are working on a revised legislation that will ensure greater flexibility. It is expected to be finalized in 2008 . Meanwhile, the ministry of labor adopted specific measures to improve the use of fixed-term contracts in the mining industry. On governance we follow the National Plan of Good Governance (Plan national de bonne gouvernance, PNBG), with a specific emphasis on the role of the State in development, the fight against corruption, and improving the legal system. The government's recently launched plan to fight corruption emphasizes the streamlining of governance institutions to increase their efficiency, especially through the creation of a single authority, whose mandate includes both general government supervision and the fight against fraud and corruption. This new authority will have the power to bring suits and will publish its reports. Burkina Faso will be one of eight countries carrying out comprehensive Governance and Anti-Corruption diagnostics with support from the World Bank in 2008. 
These diagnostics will focus on identifying the locus and vectors of corruption and will include several sector diagnostics and policy recommendations.

23. Financial sector reform will take higher priority in the future. The World Bank's financial sector review, now being finalized, will be a major input in our strategy. The review notes the financial system overall is stable, relatively efficient, and profitable. Also, it shows the bank loan portfolio is higher in quality in Burkina Faso than in the sub-region on average. However, credit ratios have deteriorated some owing to recent troubles in the cotton sector and weaker balance sheets at new banks. As recommended by the World Bank, we are considering steps to strengthen the banking and insurance systems; increase access to finance for the rural sector, housing and small and medium-sized enterprises; and improve the judicial system for credit. Moreover, we will work with the World Bank and Fund staffs on a Financial Sector Assessment Program (FSAP), scheduled to be conducted in the last quarter of 2007 for the WAEMU area and in the first quarter of 2008 for Burkina Faso.

24. Privatization will continue despite some delays. Additional government shares in ONATEL will be sold (20 percent through public offering, and 6 percent directly to ONATEL employees) by mid-2008. On the basis of a new electricity law adopted in November 2007, we are working with the World Bank to solicit bids for private management of the national electricity company (SONABEL). In addition, shares of the national oilimporting company (SONHABY) are scheduled to be sold in 2008.

\section{E. Program Monitoring}

25. The program will continue to be monitored against the agreed quantitative financial targets (Table 1) and structural performance criteria and benchmarks (Table 2) and through program reviews. The quantitative financial targets for end-December 2007 and end-June 2008 are performance criteria; those for end-March 2008 and end-September 2008 are indicative targets. The second program review is scheduled to be completed by endJuly 2008 and the third by end-January 2009. Definitions of all targeted variables and reporting requirements are contained in the attached Technical Memorandum of Understanding (TMU). The definition of the performance criterion on the overall deficit including grants was changed from the payment-order basis (base ordonnancement) to the commitment basis (base engagement) after September 30, 2007 to facilitate program monitoring. 


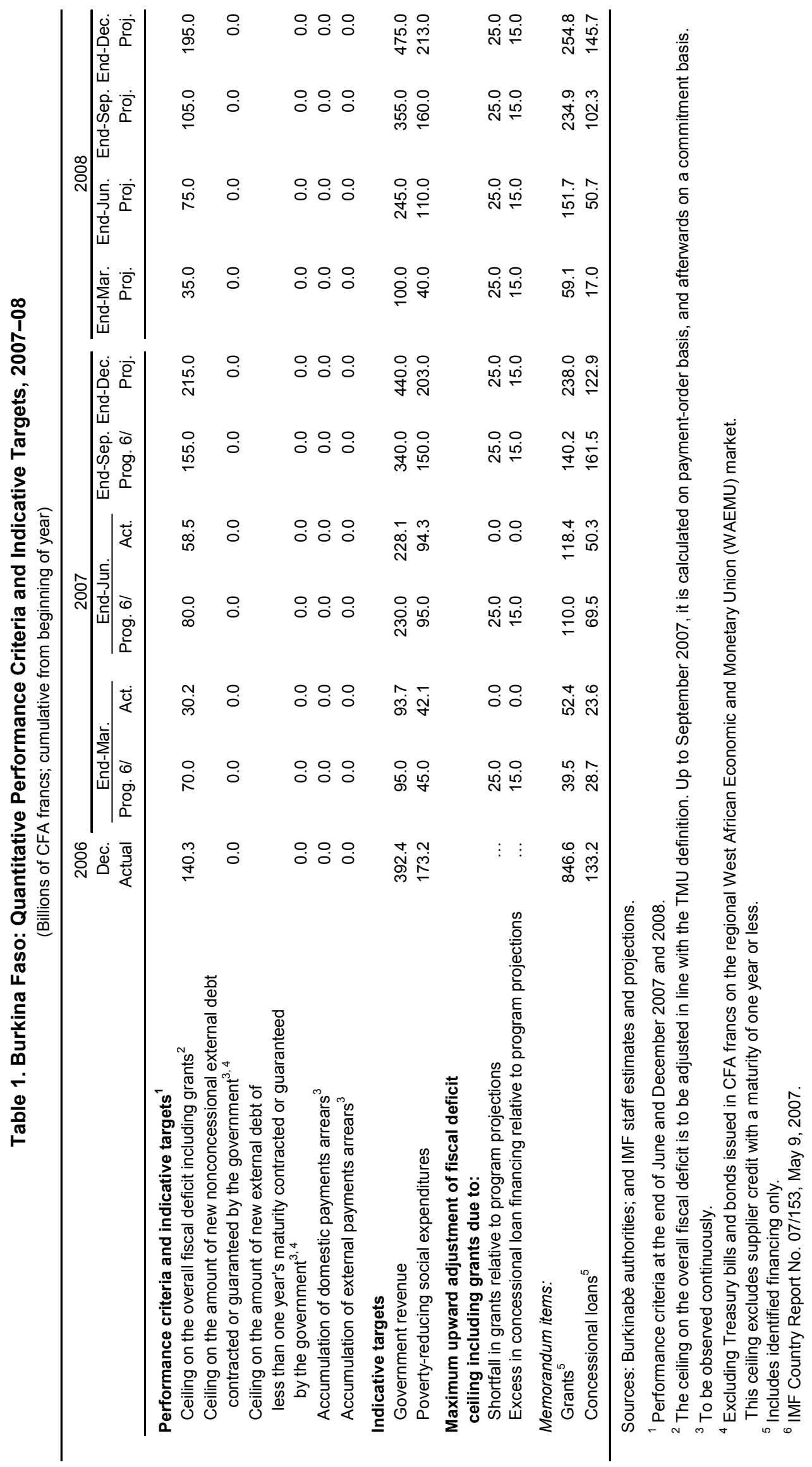


Table 2. Burkina Faso: Structural Conditionality for 2008

\begin{tabular}{lll}
\hline Measure & $\begin{array}{l}\text { Timing } \\
\text { (tentative) }\end{array}$ & $\begin{array}{l}\text { PC / } \\
\text { Benchmark }\end{array}$
\end{tabular}

Tax policy

Cabinet approval of comprehensive tax policy reform strategy (MEFP $\mathbb{1 1 6}$ ).

April 30, 2008 Benchmark

$\left(2^{\text {nd }}\right.$ review $)$

Submission to parliament of a draft 2009 budget that includes tax policy measures consistent with the tax policy reform program (MEFP \16).

Submit a comprehensive tax policy reform program to parliament (MEFP $\mathbb{0 1 6 )}$.

September 30, Benchmark 2008 $\left(3^{\text {rd }}\right.$ review $)$

December 31, 2008

Benchmark $\left(4^{\text {th }}\right.$ review $)$

\section{Tax administration}

Use Sintax to generate a list of LTO late filers and nonfilers for the main tax categories (VAT, corporate income, tax on income from securities, and tax on income from real estate), and send reminders within a week after the declaration deadline (MEFP $\mathbb{\text { I10 }}$ and $\mathbf{\uparrow 1 7}$ ).

Harmonize VAT thresholds for large, medium, and small taxpayers and subject small taxpayers to simplified taxation instead of VAT, in line with Fund recommendations (MEFP श17).

\section{Customs administration}

During the third quarter of 2008, assign at least 50 percent of customs declarations to the green and blue channels and

September 30, keep the percentage of declarations thus selected but 2008

February 1 , 2008 (start

Continuous date)

June 30, 2008

Benchmark $\left(3^{\text {rd }}\right.$ review) assigned for further controls by individual inspectors to less than 10 percent (MEFP $\mathbb{1 1 8 )}$.

\section{Public financial management and governance}

Introduce comprehensive system for tracking of povertyreducing expenditures (MEFP $\mathbb{\$ 1 9}$ ).

June 30, 2008

Benchmark ( $3^{\text {rd }}$ review)

Develop an action plan for improving the effectiveness of ex ante expenditure controls, including elimination of redundant procedures (MEFP \19).

December 31, 2008
Benchmark ( $3^{\text {rd }}$ review)
Benchmark ( $4^{\text {th }}$ review) 
Translated from French

\section{APPENDIX II. ATTACHMENT II. BURKINA Faso: TeChNiCAL MEMORANDUM OF UNDERSTANDING}

Ouagadougou, December 20, 2007

1. This memorandum defines the quantitative performance criteria and indicative targets for the program supported by the Poverty Reduction and Growth Facility (PRGF) of the International Monetary Fund (IMF). It also sets deadlines for reporting data to Fund staff to facilitate program monitoring.

\section{DEFINITIONS}

2. For the purposes of this memorandum, the following definitions of "debt," "government," "payments arrears," and "government obligations" will be used:

- Debt, as specified in point 9 of the Guidelines on Performance Criteria with Respect to Foreign Debt adopted by the Executive Board of the IMF on August 24, 2000, will be understood to mean a current, not contingent, liability, created by contract through provision of value in the form of assets (including currency) or services, that requires the obligor to make one or more payments in the form of assets (including currency) or services, at one or more future points in time; these payments being made to discharge principal and interest liabilities incurred under the contract. Debts can take a number of forms, the primary ones being:

(i) loans, consisting of advances of money to the obligor (e.g., deposits, bonds, obligations, commercial loans, and buyers' credits), who undertakes to repay the funds in the future, and temporary exchanges of assets that are equivalent to fully collateralized loans where the obligor is required to repay the funds, and usually pay interest, by repurchasing the collateral from the buyer in the future (e.g., repurchase agreements and official swap arrangements);

$>$ (ii) suppliers' credits, which are contracts where the supplier lets the obligor defer payments until after the date on which the goods have been delivered or the services provided; and

(iii) leases, which are arrangements in which property is provided for the use of the lessee for a specified period, usually shorter than the total expected life of the property, while the lessor retains title to the property. For purposes of this guideline, the debt is the present value at the inception of the lease of all lease payments expected to be made during the period of the agreement, except payments that cover the operation, repair, or maintenance of the property. 
Treasury bills and bonds issued in CFA francs on the WAEMU (West African Economic and Monetary Union) regional market are included in domestic debt for purposes of this memorandum.

- Government is defined as the central government of Burkina Faso and does not include any political subdivision, government-owned entity with a separate legal personality, or the central bank.

- External payments arrears are external payments due but unpaid. Domestic arrears are domestic payments due but unpaid after a 90-day grace period, unless the obligation specifies a different grace period.

- Government obligation is any financial obligation of the government accepted as such by the government (including any government debt).

\section{Quantitative Performance Criteria}

3. The numerical values for quantitative performance criteria, indicative targets, and adjusters are set out in Table 1 of the attached Memorandum of Economic and Financial Policies (MEFP).

\section{A. Overall Deficit Including Grants}

\section{Definition}

4. For the program, the overall deficit including grants is valued on a commitment basis (base engagement). It is defined as the sum of foreign and domestic financing (net) of the government measured from the financing side plus cash basis adjustment. Net foreign financing is the sum of foreign borrowing and debt relief minus amortization. Net domestic financing is the sum of (i) net bank credit to the government, including both net bank credit to the treasury as defined below and other government claims on and debts to national banking institutions; (ii) unredeemed government bills and bonds held outside national commercial banks; and (iii) privatization receipts. Net bank credit to the treasury is the balance of the treasury's claims and debts vis-à-vis national banking institutions. Treasury claims include the cash holdings of the Burkinabè Treasury, deposits with the central bank, deposits with commercial banks, secured obligations, and government deposits with the postal system (CCP). Treasury debt to the banking system includes funding from the central bank (including statutory advances, consolidated advances, IMF financing, and refinancing of secured obligations), government securities held by the central bank, funding from commercial banks (including government securities held by commercial banks), and CNE (Caisse Nationale d'Épargne Postale)/CCP securitized deposits. Net bank credit to the government is calculated by the Central Bank of West African States (BCEAO), whose figures are recognized as valid for program purposes. The stock of treasury bills and other government debt, as well as net foreign financing, is calculated by the Ministry of Finance. 
Cash basis adjustment is the sum of (i) expenditure commitments not-paid (engagées nonpayées); and (ii) change in treasury deposits.

5. All these items are valued according to the statement of government budgetary execution established monthly in the central government's financial operations table. This is prepared by the Permanent Secretariat for the Monitoring of Financial Policies and Programs (SP-PPF), in collaboration with the other directorates of the Ministry of Economy and Finance.

\section{Adjustment}

6. The overall deficit including grants is adjusted upward by the amount that grants fall short of what is programmed up to a maximum (see the MEFP, Table 1). It will not be adjusted if grants are higher than programmed.

7. The overall deficit including grants will also be adjusted upward by the amount that concessional loans exceed what is programmed up to a maximum (see the MEFP, Table 1).

\section{Reporting deadlines}

8. The ministry in charge of finance will forward data to the IMF on the overall deficit excluding grants within six weeks after the end of each quarter.

\section{B. Nonaccumulation of Domestic Arrears}

\section{Definition}

9. The government undertakes not to accumulate any new arrears on domestic government obligations. The treasury keeps records of such arrears and records repayments.

\section{Performance criterion}

10. The government will not accumulate any arrears on domestic government obligations during the program period. This is a performance criterion, to be observed continuously.

\section{Reporting deadlines}

11. Data on balances, accumulation, and repayment of arrears on domestic obligations will be reported within four weeks after the end of each month.

\section{Nonaccumulation of External Arrears}

\section{Performance criterion}

12. The government's external debt is the stock of debt owed or guaranteed by the government. External arrears are external payments due but not paid on the due date. Under the program, the government undertakes not to accumulate arrears on its external debt, except those arising from government debt that is being renegotiated with creditors, 
including non-Paris Club bilateral creditors. Nonaccumulation of external arrears is a performance criterion, to be observed continuously.

\section{Reporting deadlines}

13. Data on outstanding balances, accumulation, and repayment of external arrears will be forwarded within six weeks after the end of each month.

\section{Nonconcessional External Debt Contracted or Guaranteed by the Government}

\section{Performance criterion}

14. The government undertakes not to contract or guarantee any external debt maturing in one year or more that has a grant element of less than 35 percent (calculated using the interest reference rate for borrowed foreign currencies provided by the IMF) beyond the ceiling indicated in the MEFP (Table 1). This performance criterion applies not only to debt as defined in point 9 of the Guidelines (see $\$ 2$ ), but also to all commitments contracted or guaranteed for which value has not been received. However, it does not apply to treasury bills and bonds issued in CFA francs on the WAEMU regional market. This performance criterion is to be observed continuously.

\section{Reporting deadlines}

15. Details on any loan (terms and creditors) to the government or guaranteed by the government must be reported within four weeks of the end of each month.

\section{E. Government Short-Term External Debt}

16. The government undertakes not to accumulate or guarantee any new external debt with a contractual maturity of less than one year. This performance criterion applies not only to debt as defined in point 9 of the Guidelines (see 12 ), but also to commitments contracted or guaranteed for which value has not been received. Excluded from this performance criterion are import- and export-related loans and treasury bills and bonds issued in CFA francs on the WAEMU regional market and normal short-term suppliers' credits of one year or less. This performance criterion is to be observed continuously. As of April 1, 2007, the government of Burkina Faso had no short-term external debt.

\section{OTHER QUANTITATIVE INDICATIVE TARGETS}

17. The program also includes indicative targets on total government revenue and poverty-reducing social expenditures. 


\section{A. Total Government Revenue}

\section{Definition}

18. Total government revenue is valued on a cash basis. It includes all tax and nontax revenue collected by the Directorate General of Taxation, the Directorate General of Customs, the Burkinabè Treasury, and revenue collection units at ministries and institutions, and it also includes revenue from treasury checks. VAT refunds are considered as expenditures.

\section{Reporting deadlines}

19. Details on total revenue will be sent to IMF staff by the SP-PPF of the Ministry of Finance and Budget within six weeks after the end of each month.

\section{B. Poverty-Reducing Social Expenditures}

\section{Definition}

20. Poverty-reducing social expenditures are defined by the PRSP priority sector programs designed to accelerate the reduction of poverty. They cover all spending categories for the following ministries: Primary Education and Literacy; Health; Social Action and National Solidarity; Promotion of Women; Labor and Social Security; Employment and Youth; Agriculture, Water and Fishing Resources; Animal Resources; and Environment. They also cover rural roads and HIPC resources for infrastructure spending and for the Justice Ministry and the Ministry of Economy and Development. Until 2006 these expenditures were compiled from budget execution tables and from the special HIPC account. Starting in 2007 they are monitored directly through the budget, as are all HIPC resources.

\section{Reporting deadlines}

21. The government will report within six weeks after the end of each month the monthly data on poverty-reducing social expenditures.

\section{Structural Performance Criteria}

22. The program incorporates structural performance criteria (see the MEFP, Table 2 in IMF Country Report No. 07/153 (5/09/2007)).

\section{A. Nonfiler Notices}

23. The government will use Sintax to generate a list of Large Taxpayer Office (LTO) late filers and nonfilers for the main tax categories and send reminders within a week after the deadline for returns. This performance criterion will be observed on a continuous basis starting after January 31, 2008. A late filer is anyone who files a tax return after the deadline. 
A nonfiler is anyone in the database who did not file taxes. The main tax categories are the VAT (TVA), the corporate income tax (BIC), the tax on income from securities (IRVM), and the tax on income from real estate $(I R F)$. Declaration deadlines for the main tax categories are set in the tax code. The government will send reminders to at least 98 percent of the late filers and nonfilers.

\section{Additional Program-Monitoring Information}

\section{A. Public Finance}

24. The government will report the following to Fund staff:

- $\quad$ The monthly government flow-of-funds table (TOFE) and the customary appendix tables, to be forwarded within six weeks after the end of each month; if data on actual investment financed by external grants and loans are not available in time, a linear implementation estimate based on the annual projections will be used.

- $\quad$ Complete monthly data on domestic budgetary financing (net bank credit to the government and stock of unredeemed treasury bonds and bills), to be provided within six weeks after the end of each month.

- Quarterly data on implementation of the public investment program, including details on financing sources, to be sent within six weeks after the end of each quarter.

- Quarterly data on external debt stock, external debt service, signing of external loans, and disbursements of external loans, to be sent within six weeks after the end of each quarter.

- $\quad$ Monthly data on prices and the taxation of petroleum products, including (i) prices prevailing during the month; (ii) detailed calculation of the price structure, from the f.o.b.-MED price to the retail price; (iii) volumes purchased and made available for consumption by the petroleum distributor (SONABHY); and (iv) a breakdown of receipts from the taxation of petroleum products - customs duties, tax on petroleum products (TPP), and value-added tax (VAT) — and of subsidies, to be provided within four weeks after the end of each month.

- A monthly statement of the status of accounts with the treasury, classified by major category (administrative services, state enterprises, mixed enterprises, public administrative enterprises, international organizations, private depositors, and others), to be provided within six weeks after the end of each month.

- Quarterly data for the large taxpayer office on (for TVA, BIC, IRVM, and IRF) the numbers of:

$>$ registered taxpayers

declarations received on time 
reminder letters sent to late and nonfilers.

- $\quad$ These quarterly statistics are to be provided within two weeks after the end of each quarter. Similarly, quarterly data on the following are to be sent within 2 weeks of the end of the quarter:

total number of customs declarations

number of declarations selected by channel

number of declarations by channel subject non-standard treatment.

\section{B. Monetary Sector}

25. The government will provide the following information within six weeks after the end of each month:

- the consolidated balance sheet of monetary institutions

- $\quad$ provisional data on the monetary survey (with final data provided ten weeks after the end of each month)

- $\quad$ borrowing and lending interest rates

- $\quad$ customary banking supervision indicators for bank and nonbank financial institutions, if necessary.

\section{Balance of Payments}

26. The government will report the following to Fund staff:

- $\quad$ any revision of balance of payments data (including services, private transfers, official transfers, and capital transactions), as they occur

- $\quad$ foreign trade statistics compiled by the National Statistics Institute, within three months after the end of the month concerned

- $\quad$ preliminary annual balance of payments data within nine months after the end of the year concerned.

\section{Real Sector}

27. The government will report the following to Fund staff:

- $\quad$ disaggregated monthly consumer price indices, within two weeks after the end of each month

- $\quad$ provisional national accounts

- $\quad$ any revision of the national accounts. 


\section{E. Structural Reforms and Other Data}

28. The government will also report the following:

- $\quad$ any study or official report on Burkina Faso's economy, within two weeks after its publication

- $\quad$ any decision, order, law, decree, ordinance, or circular that has economic or financial implications as soon as it is published or at the latest when it enters into force. 


\section{Summary of Data Requirements}

\begin{tabular}{|c|c|c|c|}
\hline Type of Data & Tables & Frequency & Reporting Deadline \\
\hline \multirow[t]{3}{*}{ Real sector } & Provisional national accounts & Variable & $\begin{array}{l}\text { End of provisional } \\
\text { estimate + eight weeks }\end{array}$ \\
\hline & Revisions of national accounts & Variable & $\begin{array}{l}\text { End of revision }+ \\
\text { eight weeks }\end{array}$ \\
\hline & Disaggregated consumer price index & Monthly & $\begin{array}{l}\text { Month's end + two } \\
\text { weeks }\end{array}$ \\
\hline \multirow[t]{8}{*}{ Public finance } & $\begin{array}{l}\text { Net treasury and government position at the } \\
\text { BCEAO and details of nonbank financing, } \\
\text { including the stock of treasury bills and bonds }\end{array}$ & Monthly & Month's end + six weeks \\
\hline & $\begin{array}{l}\text { Government flow-of-funds table (TOFE) and the } \\
\text { customary appendix tables }\end{array}$ & Monthly & Month's end + six weeks \\
\hline & Execution of capital budget & Quarterly & $\begin{array}{l}\text { End of quarter }+ \\
\text { six weeks }\end{array}$ \\
\hline & Poverty-reducing social expenditures & Monthly & Month's end + six weeks \\
\hline & Structural of prices for petroleum products & Monthly & $\begin{array}{l}\text { Month's end + } \\
\text { four weeks }\end{array}$ \\
\hline & $\begin{array}{l}\text { Status of the deposit accounts with the public } \\
\text { treasury, classified by major category }\end{array}$ & Monthly & Month's end + six weeks \\
\hline & Statistics of the LTO on tax filings. & Quarterly & $\begin{array}{l}\text { End of quarter }+ \text { two } \\
\text { weeks }\end{array}$ \\
\hline & Statistics on customs declarations. & Quarterly & $\begin{array}{l}\text { End of quarter }+ \text { four } \\
\text { weeks }\end{array}$ \\
\hline \multirow{4}{*}{$\begin{array}{l}\text { Monetary and } \\
\text { financial data }\end{array}$} & Monetary survey & Monthly & Month's end + six weeks \\
\hline & Consolidated balance sheet of monetary institutions & Monthly & Month's end + six weeks \\
\hline & Borrowing and lending interest rates & Monthly & Month's end + six weeks \\
\hline & Banking supervision ratios & Quarterly & $\begin{array}{l}\text { End of quarter }+ \\
\text { eight weeks }\end{array}$ \\
\hline \multirow[t]{3}{*}{$\begin{array}{l}\text { Balance of } \\
\text { payments }\end{array}$} & Balance of payments & Annual & $\begin{array}{l}\text { End of year }+ \\
\text { nine months }\end{array}$ \\
\hline & Trade statistics & Quarterly & $\begin{array}{l}\text { End of quarter }+ \\
\text { eight weeks }\end{array}$ \\
\hline & Revised balance of payments data & Variable & When revisions occur \\
\hline \multirow[t]{2}{*}{ External debt } & $\begin{array}{l}\text { Outstanding external debt stock, arrears and } \\
\text { repayments (if applicable) }\end{array}$ & Quarterly & $\begin{array}{l}\text { End of quarter }+ \\
\text { six weeks }\end{array}$ \\
\hline & Details of all new external borrowing & Quarterly & $\begin{array}{l}\text { End of quarter + } \\
\text { four weeks }\end{array}$ \\
\hline
\end{tabular}





\title{
INTERNATIONAL MONETARY FUND
}

\author{
BURKINA FASO
}

\section{Article IV Consultation, First Review Under the Poverty Reduction and Growth Facility, Requests for Access Augmentation, Requests for Waivers for Nonobservance of Performance Criteria, and Request for Modification of Performance Criteria}

\section{Informational Annex}

Prepared by the African Department

(In collaboration with other departments)

Approved by Thomas Krueger and Mark Plant

December 20, 2007

- Relations with the Fund. Describes financial and technical assistance from the Fund and provides information on the safeguards assessment and exchange rate system. Outstanding purchases and loans amounted to SDR 23.72 million (39.4 percent of quota) at end-October 2007.

- $\quad$ Relations with the World Bank. Describes the World Bank Group program and portfolio, including a statement of IFC investments.

- $\quad$ Statistical Issues. Assesses the quality of statistical data. Weaknesses in a broad range of economic statistics are hampering the analyses of economic developments in the country. 


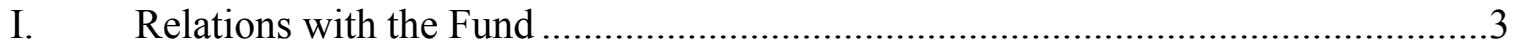

II. Relations with the World Bank Group.............................................................11

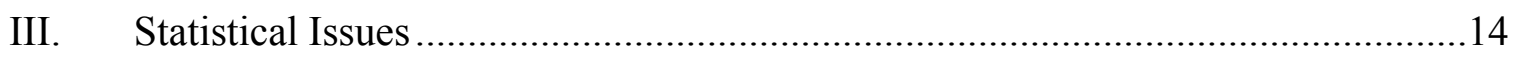


APPENDIX I. BURKINA FASO: RELATIONS WITH THE FUND

(As of October 31, 2007)

I. Membership Status: Joined: May 2, 1963; accepted Article VIII in June 1996

II. General Resources Account:

Quota

Fund holdings of currency

Reserve position in Fund

Holdings Exchange Rate

III. SDR Department:

Net cumulative allocation

Holdings

IV. Outstanding Purchases and Loans:

Poverty Reduction and Growth Facility (PRGF) arrangements

V. Latest Financial Arrangements:

$\begin{array}{lll}\text { Type } & \text { Approval } & \text { Expiration } \\ \text { Date } & \underline{\text { Date }}\end{array}$

PRGF

PRGF

Apr. 23, 2007

Jun. 11, 2003

PRGF
SDR Million

60.20

52.82

7.39

SDR Million

9.41

0.09

SDR Million

23.72

Apr. 22, 2010

Sept. 30, 2006

Dec. 09, 2002
In percent of quota 100.00

87.74

In percent of allocation

100.00

0.94

In percent of quota 39.40

VI. Projected Payments to Fund

(SDR million; based on existing use of resources and present holdings of SDRs):

Forthcoming

Principal

$\begin{array}{lllll}\underline{2007} & \underline{2008} & \underline{2009} & \underline{2010} & \underline{2011} \\ 0.15 & 0.48 & 0.48 & 0.49 & 2.41 \\ 0.15 & 0.48 & 0.48 & 1.17 & 2.88\end{array}$

Total Amount Approved Amount Drawn (SDR Million) (SDR Million)

$\begin{array}{rr}6.02 & 0.50 \\ 30.10 & 30.10 \\ 39.12 & 39.12\end{array}$

0.50

39.12 


\section{Implementation of HIPC Initiative:}

\section{Commitment of HIPC assistance}

Decision point date

Assistance committed

by all creditors (US\$ Million) ${ }^{18}$

Of which: IMF assistance (US\$ million)

(SDR equivalent in millions)

Completion point date

II. Disbursement of IMF assistance (SDR Million)

Assistance disbursed to the member

Interim assistance

Completion point balance

Additional disbursement of interest income ${ }^{19}$

Total disbursements
Original Enhanced

Framework $\underline{\text { Framework } \quad \underline{\text { Total }}}$

Sept. 1997

Jul. 2000

229.00

324.15

21.70

35.88

$16.30 \quad 27.67$

Jul. 2000 Apr. 2002

16.30

27.67

43.97

4.15

23.52

4.15

16.30

2.01

39.82

2.01

16.30

29.68

\section{Implementation of MDRI Assistance:}

I. Total Debt Relief (SDR Million) $)^{20}$

62.12

Of which: MDRI

57.06

Of which: HIPC

II. Debt Relief by Facility (SDR Million)

5.06

\section{$\underline{\text { Eligible Debt }}$}

Delivery date

January 2006
GRA

N/A
PRGF

62.12
Total

62.12

\footnotetext{
${ }^{18}$ Assistance committed under the original framework is expressed in net present value (NPV) terms at the completion point, and assistance committed under the enhanced framework is expressed in NPV terms at the decision point. Hence, these two amounts cannot be added.

${ }^{19}$ Under the enhanced framework, an additional disbursement is made at the completion point corresponding to interest income earned on the amount committed at the decision point, but not disbursed during the interim period.

${ }^{20}$ The Multilateral Debt Relief Initiative (MDRI) provides 100 percent debt relief to eligible member countries that are qualified for the assistance. Grant assistance from the MDRI Trust and HIPC resources provide debt relief to cover the full stock of debt owed to the Fund as of end-2004 that remains outstanding at the time the member qualifies for such debt relief.
} 


\section{Safeguards Assessments:}

The Central Bank of West African States (BCEAO) is a common central bank of the countries of the West African Economic and Monetary Union that includes Burkina Faso.

The most recent safeguards assessment of the BCEAO was completed on November 4, 2005. The assessment indicated progress has been made in strengthening the bank's safeguards framework since the 2002 assessment and identified some areas where further steps would help solidify it.

The BCEAO now publishes a full set of audited financial statements and improvements have been made to move financial reporting closer to International Financial Reporting Standards (IFRS). Furthermore, an internal audit charter has been put in place, mechanisms for improving risk management have been established and follow-up on internal and external audit recommendations has been strengthened.

The monitoring results of the first half of 2007 indicate certain vulnerabilities remain in internal control systems and legal structure, while there has been some progress in improving the external audit process (through adopting a multi year audit program), establishing an audit committee, expanding disclosures in the notes to financial statements on financial positions with the Fund by countries, and further strengthening of the effectiveness of the internal audit function.

\section{Exchange Rate Arrangement:}

Burkina Faso is a member of the West African Economic and MonetaryUnion (WAEMU) and has no separate legal tender. The union's common currency, the CFA franc, is pegged to the euro at a rate of CFAF $655.957=$ EUR 1, consistent with the official conversions rate of the French franc to the Euro and the previous fixed rate of the CFA franc to the French franc of CFAF $100=$ F 1 . On April 28, 2006, the rate of the CFA franc in terms of SDR was CFAF $769.68=$ SDR 1.0. Effective January 1, 2007, the exchange arrangement of the WAEMU countries has been reclassified to the category of conventional pegged arrangement from the category of exchange arrangement with no separate legal tender. The new classification is based on the behavior of the common currency, whereas the previous classification was based on the lack of a separate legal tender. The new classification thus only reflects a definitional change, and is not based on a judgment that there has been a substantive change in the exchange regime or other policies of the currency union or its member. The exchange system is free of restrictions on the making of payments and transfers on current international transactions.

\section{Article IV Consultations:}

The periodicity of Burkina Faso's Article IV consultation is set in accordance with the July 15, 2002 Executive Board Decision on consultation cycles. Discussions on the 2005 Article IV consultation and fourth review under the Poverty Reduction and Growth Facility (PRGF) were held during the period May 24-June 9, 2005 in Ouagadougou. The staff report 
(IMF Country report No. 05/354, September 30, 2005) and the Selected Issues and Statistical Annex (IMF Country Report No. 05/358, September 30, 2005) were considered by the Executive Board on September 7, 2005.

\section{ROSC/AAP:}

An FAD mission visited Ouagadougou during May 7-18, 2001 to assist the authorities undertake a draft fiscal module of a Report on the Observance of Standards and Codes (ROSC). The final report, which was issued in July 2002, found that Burkina Faso was making good progress in a number of areas to increase the transparency and accountability of government. Additional efforts are needed to bring a number of improvements to the point of implementation, particularly with regard to expenditure tracking at the local level and external audit functions. Initial discussions indicated that the authorities broadly concurred with the mission assessment. On July 31,2002 , the authorities formally adopted an action plan based on the recommendations of the final ROSC.

An STA mission during May 8-21, 2003 assisted the authorities in preparing a data ROSC. The report was published in March 2004. The mission found that most of the methodologies used in the compilation of macroeconomic statistics are in broad conformity with internationally accepted guidelines. However, most datasets are affected by limited or impaired source data arising from irregularity in the conduct of surveys (national accounts), use of outdated weights (CPI), or low response rate to surveys (balance of payments). For $\mathrm{CPI}$ and government finance statistics, data dissemination meets the SDDS requirement, but for other macroeconomic datasets, timeliness falls short of GDDS recommendations. The authorities broadly concurred with the main findings of the mission as well as the recommendations made to address them.

The team, jointly with World Bank staff, also discussed a HIPC Initiative Assessment and Action Plan (AAP) with the authorities. The aim was to assess the capacity of the public expenditure management system to track poverty-reducing public expenditures under the HIPC Initiative and the need for technical assistance to enhance that capacity. The mission secured the officials' approval of the jointly prepared preliminary assessment; identified the main needs for technical assistance on upgrading the capacity to track such expenditures; and drew up a draft outline action plan. This plan identifies the main needs for further technical assistance to improve tracking of poverty-reducing expenditures. The AAP has been endorsed by the authorities. 


\section{Technical Assistance:}

Significant technical assistance has been provided since 1989, more recently especially in the fiscal area:

\begin{tabular}{|c|c|c|c|}
\hline Department & $\begin{array}{l}\text { Type of } \\
\text { Assistance }\end{array}$ & Time of Delivery & Purpose \\
\hline AFRITAC & Tax Advisor & $\begin{array}{l}\text { February 7-11, } \\
2005\end{array}$ & $\begin{array}{l}\text { Review the progress made on: } \\
\text { (1) the setup of the Large Taxpayer } \\
\text { Unit and the Medium Taxpayers } \\
\text { Office; (2) the steps to strengthen } \\
\text { the fiscal control; and (3) the } \\
\text { corporate registry reform. }\end{array}$ \\
\hline AFRITAC & $\begin{array}{l}\text { Customs } \\
\text { Advisor }\end{array}$ & $\begin{array}{l}\text { February 14-18, } \\
2005\end{array}$ & $\begin{array}{l}\text { Provide assistance to control transit } \\
\text { merchandises in the country and } \\
\text { travelers at Ouagadougou airport. }\end{array}$ \\
\hline AFRITAC & $\begin{array}{l}\text { Customs, short- } \\
\text { term Expert }\end{array}$ & $\begin{array}{l}\text { February 14-23, } \\
2005\end{array}$ & $\begin{array}{l}\text { Implement customs valuation code } \\
\text { and establish a database for } \\
\text { indicative import prices. }\end{array}$ \\
\hline AFRITAC & $\begin{array}{l}\text { Microfinance } \\
\text { Advisor }\end{array}$ & March 21-25, 2005 & $\begin{array}{l}\text { Assess the TA need of the Cellule } \\
\text { responsible of the supervision of } \\
\text { microfinance institutions and } \\
\text { prepare a capacity-building } \\
\text { program. }\end{array}$ \\
\hline AFRITAC & $\begin{array}{l}\text { Short-term } \\
\text { Expert }\end{array}$ & April 18-29, 2005 & $\begin{array}{l}\text { Training of auditors of the Tax } \\
\text { administration. }\end{array}$ \\
\hline AFRITAC & PEM Advisor & $\begin{array}{l}\text { June 27, July 1, } \\
2005\end{array}$ & $\begin{array}{l}\text { Review of the public finance } \\
\text { directives of WAEMU. }\end{array}$ \\
\hline AFRITAC & $\begin{array}{l}\text { STA Advisor } \\
\text { and Short-term } \\
\text { Expert }\end{array}$ & $\begin{array}{l}\text { June 27-July 5, } \\
2005\end{array}$ & $\begin{array}{l}\text { Assist in setting up database for the } \\
\text { TOFE (first or two scheduled } \\
\text { missions) and expand further the } \\
\text { scope of the TOFE (last of three } \\
\text { scheduled missions). }\end{array}$ \\
\hline AFRITAC & $\begin{array}{l}\text { Customs } \\
\text { Advisor visits }\end{array}$ & July $10-16,2005$ & $\begin{array}{l}\text { Advise on customs enforcement and } \\
\text { assessment of further TA needs. }\end{array}$ \\
\hline AFRITAC & Tax Advisor & August 8-12, 2005 & $\begin{array}{l}\text { (1) Review the status of } \\
\text { implementation of the } 2003 \text { FAD } \\
\text { mission's recommendations; } \\
\text { (2) update the tax directorate's } \\
\text { action plan; and (3) asses the DGI } \\
\text { TA's needs. }\end{array}$ \\
\hline
\end{tabular}




\begin{tabular}{|c|c|c|c|}
\hline Department & $\begin{array}{l}\text { Type of } \\
\text { Assistance }\end{array}$ & Time of Delivery & Purpose \\
\hline AFRITAC & $\begin{array}{l}\text { STA Short-term } \\
\text { Expert }\end{array}$ & $\begin{array}{l}\text { August 22-26, } \\
2005\end{array}$ & $\begin{array}{l}\text { Assist with putting in place the } \\
\text { database of public finances. }\end{array}$ \\
\hline AFRITAC & $\begin{array}{l}\text { Customs } \\
\text { Advisor }\end{array}$ & $\begin{array}{l}\text { August } 28- \\
\text { September } 1,2005\end{array}$ & $\begin{array}{l}\text { Advise on customs enforcement and } \\
\text { assessment of further TA needs. }\end{array}$ \\
\hline AFRITAC & $\begin{array}{l}\text { STA Short-term } \\
\text { Expert }\end{array}$ & $\begin{array}{l}\text { August 29- } \\
\text { September 2, } 2005\end{array}$ & $\begin{array}{l}\text { Assist and set up database for the } \\
\text { TOFE (last of the two scheduled } \\
\text { missions). }\end{array}$ \\
\hline AFRITAC & $\begin{array}{l}\text { Microfinance } \\
\text { Advisor }\end{array}$ & $\begin{array}{l}\text { September 19-23, } \\
2005\end{array}$ & $\begin{array}{l}\text { Strengthen operational systems for } \\
\text { the surveillance of microfinance } \\
\text { institutions. }\end{array}$ \\
\hline AFRITAC & $\begin{array}{l}\text { STA Short-term } \\
\text { Expert }\end{array}$ & $\begin{array}{l}\text { September 19-23, } \\
2005\end{array}$ & $\begin{array}{l}\text { Assist and setting up database for } \\
\text { the TOFE (additional mission). }\end{array}$ \\
\hline AFRITAC & PEM Advisor & $\begin{array}{l}\text { October 10-14, } \\
2005\end{array}$ & $\begin{array}{l}\text { Review the status of } \\
\text { implementation the January } 2004 \\
\text { mission recommendations and } \\
\text { assess the technical assistance } \\
\text { needs. }\end{array}$ \\
\hline AFRITAC & $\begin{array}{l}\text { Microfinance } \\
\text { Advisor and } \\
\text { Short-term } \\
\text { Expert }\end{array}$ & $\begin{array}{l}\text { November } 21- \\
\text { December } 16,2005\end{array}$ & Coach in microfinance inspections. \\
\hline AFRITAC & STA Advisor & $\begin{array}{l}\text { December 6-15, } \\
2005\end{array}$ & $\begin{array}{l}\text { Review the WAEMU directives on } \\
\text { budgetary nomenclature. }\end{array}$ \\
\hline AFRITAC & $\begin{array}{l}\text { Customs } \\
\text { Advisor }\end{array}$ & $\begin{array}{l}\text { January 23-25, } \\
2006\end{array}$ & $\begin{array}{l}\text { Strengthen the dialogue between the } \\
\text { customs administration and the } \\
\text { private sector (regional workshop). }\end{array}$ \\
\hline AFRITAC & STA Advisor & March 11-25, 2006 & Review the directive on the TOFE. \\
\hline AFRITAC & PEM Advisor & March 13-17, 2006 & Review the directive on the TOFE. \\
\hline AFRITAC & $\begin{array}{l}\text { Tax } \\
\text { administration; } \\
\text { Short term } \\
\text { Expert }\end{array}$ & March 14-28, 2006 & $\begin{array}{l}\text { Assist in strengthening (1) } \\
\text { operations of the LTU; and (2) tax } \\
\text { auditing. }\end{array}$ \\
\hline AFRITAC & $\begin{array}{l}\text { Customs } \\
\text { Advisor }\end{array}$ & March 14-28, 2006 & $\begin{array}{l}\text { Assist in defining an action plan to } \\
\text { improve revenue mobilization. }\end{array}$ \\
\hline
\end{tabular}




\begin{tabular}{|c|c|c|c|}
\hline Department & $\begin{array}{l}\text { Type of } \\
\text { Assistance }\end{array}$ & Time of Delivery & Purpose \\
\hline FAD & $\begin{array}{l}\text { Revenue } \\
\text { administration } \\
\text { mission }\end{array}$ & March 14-28, 2006 & $\begin{array}{l}\text { Advise on tax and customs } \\
\text { administration reform strategy } \\
\text { (including improvement of the large } \\
\text { tax payer unit, and strengthening of } \\
\text { the tax and customs organization } \\
\text { and operations). }\end{array}$ \\
\hline AFRITAC & Custom Advisor & April 4-14, 2006 & $\begin{array}{l}\text { Strengthen the control of goods } \\
\text { valuation. }\end{array}$ \\
\hline AFRITAC & $\begin{array}{l}\text { Tax } \\
\text { administration; } \\
\text { Short term Expert }\end{array}$ & April 17-28, 2006 & $\begin{array}{l}\text { Strengthen the management of the most } \\
\text { important taxpayers. }\end{array}$ \\
\hline AFRITAC & Tax Advisor & July 24-28, 2006 & $\begin{array}{l}\text { Follow up the implementation of } \\
\text { the recommendations by the FAD } \\
\text { mission in March } 2006 \text {. }\end{array}$ \\
\hline AFRITAC & $\begin{array}{l}\text { Microfinance } \\
\text { Advisor }\end{array}$ & $\begin{array}{l}\text { July } 31 \text {-August } 4 \text {, } \\
2006\end{array}$ & $\begin{array}{l}\text { Identify the follow-up indicators } \\
\text { from a distance. }\end{array}$ \\
\hline AFRITAC & $\begin{array}{l}\text { Real statistic } \\
\text { sector Advisor }\end{array}$ & $\begin{array}{l}\text { September 11-20, } \\
2006\end{array}$ & $\begin{array}{l}\text { Take stock of the implementation of } \\
\text { the recommendations by the ROSC } \\
\text { mission in March } 2004 \text {. }\end{array}$ \\
\hline AFRITAC & $\begin{array}{l}\text { Microfinance, } \\
\text { Short term } \\
\text { Expert }\end{array}$ & $\begin{array}{l}\text { September } 28- \\
\text { October 20, } 2006\end{array}$ & $\begin{array}{l}\text { Accompany the agents of the Cell } \\
\text { S-IFD }\end{array}$ \\
\hline AFRITAC & $\begin{array}{l}\text { Public } \\
\text { expenditure } \\
\text { Advisors }\end{array}$ & October $2-12,2006$ & $\begin{array}{l}\text { Review and follow up the } \\
\text { implementation of the priority } \\
\text { action plan in the PF strengthening } \\
\text { strategy. }\end{array}$ \\
\hline AFRITAC & $\begin{array}{l}\text { Microfinance; } \\
\text { Short term } \\
\text { Expert }\end{array}$ & October 2-20, 2006 & $\begin{array}{l}\text { Develop agent's abilities in } \\
\text { inspection and accompany them in } \\
\text { the field. }\end{array}$ \\
\hline AFRITAC & $\begin{array}{l}\text { Customs } \\
\text { administration, } \\
\text { Short-term } \\
\text { Expert }\end{array}$ & $\begin{array}{l}\text { November } 20- \\
\text { December } 1,2006\end{array}$ & $\begin{array}{l}\text { Assess the implementation of } \\
\text { preview recommendations relating } \\
\text { to the control of goods valuation in } \\
\text { the customs. }\end{array}$ \\
\hline AFRITAC & Tax Advisor & $\begin{array}{l}\text { November } 20- \\
\text { December } 1,2006\end{array}$ & $\begin{array}{l}\text { Strengthen capacities of the tax } \\
\text { administration to fight tax evasion. }\end{array}$ \\
\hline AFRITAC & $\begin{array}{l}\text { Macroeconomic } \\
\text { statistics } \\
\text { Advisor }\end{array}$ & March 5-9, 2007 & $\begin{array}{l}\text { Training in Government Statistics } \\
\text { Manual } 2001\end{array}$ \\
\hline
\end{tabular}




\begin{tabular}{|c|c|c|c|}
\hline Department & $\begin{array}{l}\text { Type of } \\
\text { Assistance }\end{array}$ & Time of Delivery & Purpose \\
\hline AFRITAC & Debt Advisor & March 5-16, 2007 & $\begin{array}{l}\text { Study the situation of the } \\
\text { administrative management of the } \\
\text { internal and external debts. }\end{array}$ \\
\hline AFRITAC & $\begin{array}{l}\text { Customs } \\
\text { Advisor }\end{array}$ & March 12-23, 2007 & $\begin{array}{l}\text { Follow up the implementation of } \\
\text { the recommendations by the FAD } \\
\text { mission in March } 2006 \text {, and assess } \\
\text { the implementation of the goods } \\
\text { valuation control in the customs. }\end{array}$ \\
\hline AFRITAC & $\begin{array}{l}\text { Macroeconomic } \\
\text { statistics } \\
\text { Advisor }\end{array}$ & March 19-23, 2007 & $\begin{array}{l}\text { Training in Government finance } \\
\text { statistics framework. }\end{array}$ \\
\hline AFRITAC & Tax Advisor & March 26-30, 2007 & $\begin{array}{l}\text { Assist in the implementation of the } \\
\text { tax administration strengthening } \\
\text { and modernization measures. }\end{array}$ \\
\hline $\mathrm{MCM}$ & $\begin{array}{l}\text { Bank } \\
\text { supervision }\end{array}$ & July 23-27, 2007 & $\begin{array}{l}\text { Technical assistance needs } \\
\text { assessment and evaluation on bank } \\
\text { supervision }\end{array}$ \\
\hline FAD & $\begin{array}{l}\text { Revenue } \\
\text { administration } \\
\text { mission }\end{array}$ & & $\begin{array}{l}\text { Advise on tax and customs } \\
\text { administration reform strategy } \\
\text { (including improvement of the large } \\
\text { tax payer unit, and strengthening of } \\
\text { the tax and customs organization } \\
\text { and operations). }\end{array}$ \\
\hline $\begin{array}{l}\text { FAD/ } \\
\text { AFRITAC }\end{array}$ & $\begin{array}{l}\text { Public financial } \\
\text { management }\end{array}$ & & $\begin{array}{l}\text { Assist in the implementation of the } \\
\text { authorities' reform agenda in public } \\
\text { financial management. }\end{array}$ \\
\hline
\end{tabular}

XIV. Resident Representative:

Mr. Mario Zejan took up the post of Resident Representative in March 2004. 


\section{APPENDIX II. BURKINA FASO: IMF-WORLD BANK RELATIONS}

(As of December 10, 2007)

\section{A. Partnership in Burkina Faso's development strategy}

Government's development strategy. The government of Burkina Faso outlined its development strategy in a revised PRSP (PRSP-2) adopted by the Council of Ministers on October 27, 2004, along with a Priority Action Program (PAP). The PAP translates strategic objectives into sequenced actions and strengthens results-based monitoring of the PRSP. The revised PRSP and accompanying PAP were presented to World Bank and IMF Boards on May 3, 2005. PRSP-2 reaffirms the four interrelated pillars as identified in the first PRSP, namely: (i) accelerating broad-based growth; (ii) promoting access to social services; (iii) increasing employment and income-generating activities for the poor; and (iv) promoting good governance.

Partnership with the Fund. The IMF and World Bank staffs maintain a collaborative relationship in supporting the government's macroeconomic and structural reforms, in line with the guidelines for enhanced Bank-Fund collaboration. This includes regular participation of Bank staff in the meetings with the government on the Fund's program review missions, IMF staff participation in Bank development policy missions, and Bank internal review meetings. The IMF takes the lead in macroeconomic stabilization and the World Bank in economic growth and poverty reduction, with close collaboration on overlapping issues. The Fund's dialogue and conditionality are consistent with the structural programs agreed with the Bank, and the Bank's dialogue and conditionality have maintained consistency with the macroeconomic framework endorsed by the Fund.

\section{B. World Bank Group Strategy}

29. On June 28, 2005 the Bank's Board discussed the World Bank Group's country assistance strategy (CAS FY2006-09). This CAS supports the pillars of PRSP-2 with analytic work, technical advice, on-going operations and new financing. It is built around a results framework that explicitly defines the assumed causal links between IDA-supported activities, direct outcomes of these activities and the country's higher-level development outcomes. On July5, 2007 the Bank's Board discussed the CAS Progress Report which emphasized that the CAS remains highly relevant for Burkina Faso and is being effectively implemented to deliver results in the following key strategic areas:

- Accelerated and shared growth. IDA will support enhanced regional integration, expanded and diversified export earnings, cotton sector reform, an improved investment climate, decentralized urban development to promote urban-rural linkages, and economic infrastructure needed to reduce factor costs and stimulate private sector investment and growth. 
- Improved access to basic social services. IDA will continue to support access to education and improved quality of teaching, expanded coverage of basic health care and HIV/AIDS prevention and treatment and increased access to clean water and sanitation, particularly in urban areas.

- Increased employment and income opportunities for the poor. A two-pronged approach will focus, first, on the labor market and employment strategy for urban workers. Second, IDA will support efforts to reduce risk, increase revenues, upgrade economic and market infrastructure and enhance women's opportunities in rural areas, along with promoting community-based land and natural resource management for sustainable development.

- Better governance with greater decentralization. Governance affects the achievement of development outcomes across all strategic pillars and sectors. Efforts to enhance governance and accountability will be integral to all IDA-supported activities. Particular emphasis will be placed on supporting a more efficient judiciary, promoting public resource management and increased decentralization and strengthening local government's capacity and participation in public policy decisions.

30. The current Bank Portfolio comprises 14 IDA and 2 GEF commitments of US\$ 579.7 million, of which US\$ 418 million are undisbursed. IDA's detailed portfolio in Burkina Faso is as follows:

Burkina Faso: Financial Relations with the World Bank (As of November 21, 2007; in millions of U.S. dollars)

\begin{tabular}{|l|r|r|r|}
\hline \multicolumn{1}{|c|}{ IDA Lending Operations } & $\begin{array}{c}\text { Approval } \\
\text { Date }\end{array}$ & $\begin{array}{c}\text { IDA/GEF } \\
\text { Commitments in } \\
\text { US\$ Million }\end{array}$ & $\begin{array}{c}\text { Undisbursed } \\
\text { Amount of } \\
\text { Active Projects }\end{array}$ \\
\hline Energy Access Project & $07 / 26 / 2007$ & 38.8 & 39.2 \\
\hline Decentralized Urban Capacity Building & $05 / 29 / 2007$ & 10.0 & 10.4 \\
\hline Community Based Rural Development & $03 / 27 / 2007$ & 74.0 & 75.6 \\
\hline Agriculture Diversification \& Market Development & $06 / 20 / 2006$ & 66.0 & 68.3 \\
\hline Post Primary Education & $06 / 20 / 2006$ & 22.9 & 17.2 \\
\hline Health Sector Sup. \& AIDS & $04 / 27 / 2006$ & 47.7 & 46.9 \\
\hline Admin Capacity Building & $03 / 22 / 2005$ & 7.0 & 5.1 \\
\hline Power Sector Development & $11 / 30 / 2004$ & 4.5 & 45.9 \\
\hline GEF Sahel Lowland Ecosys Mgmt & $06 / 22 / 2004$ & 10.0 & 2.3 \\
\hline STATCAP & $03 / 25 / 2004$ & 92.1 & 4.1 \\
\hline Transp Sector & $04 / 08 / 2003$ & 30.7 & 65.8 \\
\hline Compet \& Enterprise Development & $03 / 04 / 2003$ & 2.3 & 24.7 \\
\hline Development Learning Center & $07 / 29 / 2002$ & 7.5 & 32.6 \\
\hline GEF Nat Res Mgmt Partnership & $05 / 21 / 2002$ & 70.0 & $\mathbf{5 7 9 . 7}$ \\
\hline Basic Education Sector & $01 / 22 / 2002$ & 0.1 \\
\hline Ouaga Water Supply & $03 / 20 / 2001$ & & 0.0 \\
\hline Total & & 418.0 \\
\hline
\end{tabular}

Source: World Bank. 
31. The Bank's proposed remaining lending program for the FY06-09 period $^{21}$ will consist of: one programmatic development lending operation per fiscal year; and investment operations potentially in the water and education sectors subject to discussions with the Government and IDA availability. In addition, Burkina will participate in regional projects to improve infrastructure networks and increase agricultural productivity ${ }^{22}$.

\section{IMF-World Bank collaboration}

32. Areas in which the Fund leads. The Fund takes the lead in the policy dialogue on macroeconomic policies and monitors macroeconomic performance through quantitative performance criteria. In addition, it has established structural performance criteria in the areas of tax policy, financial transparency and good governance, and trade policy.

33. Areas in which the Bank leads. The Bank takes the lead in economic growth and poverty reduction The Bank is supporting the implementation of the PRSP in the areas of cotton sector reform, public finance management, good governance, decentralization, energy sector and economic diversification and competitiveness through a series of poverty reduction support credits (PRSC), complemented with a portfolio of specific projects addressing issues related to HIV/AIDS, education, infrastructure investments in transport, water and sanitation, urban and rural development, private sector development, and statistical capacity building.

34. Areas of shared responsibility. The staffs of the Bank and Fund consult with each other on a regular basis on all aspects of the policy dialog in order to ensure a well coordinated approach. Bank and Fund staffs are expected to attend Board discussions in the other institution, and will normally be called to the table to present their views on areas of the reform program where their institution is in the lead. Bank and Fund staffs collaborate as needed on a variety of topics in ways that are consistent with their areas of emphasis. These include but are not limited to the following: debt sustainability assessments; level and composition of public expenditures; public financial management; anti-corruption efforts; and HIPC resource use.

\footnotetext{
${ }^{21}$ FY09 IDA allocation will depend on IDA 15 negotiations currently underway.

${ }^{22}$ A regional aviation project, a regional transit facilitation project, a West Africa power pool project and a West African agricultural productivity program.
}

Prepared by World Bank staff. Questions may be referred to Mr. Gilles Alfandari (Sr. Economist, phone: 202458-9498). 


\section{APPENDIX III. BURKINA FASO: STATISTICAL IsSUES}

Overall, data provision is adequate for surveillance purposes, but serious shortcomings hamper economic and program monitoring. The country has participated in the General Data Dissemination System (GDDS) since December 2001 and its metadata are posted on the Dissemination Standards Bulletin Board (DSBB). However, the metadata have not been updated since 2001. Following the conversion of the National Institute of Statistics and Demography (INSD) into an autonomous agency, its human and material resources were significantly increased in 2002.

The country has received technical assistance (TA) under the government finance statistics (GFS) component of the regional GDDS project (funded by Japan) for member countries of the West African Economic and Monetary Union (WAEMU). ${ }^{23}$ A data ROSC mission visited Burkina Faso in May 2003 and the report was published in March 2004. The May 2006 and September 2006 STA missions helped the authorities update the statistical plans for improvement and recommended increasing resources to support statistical reforms, especially to the INSD, for additional staff and survey work. This was seen as a prerequisite to enhanced overall effectiveness of technical assistance.

\section{Real sector}

Serious problems have been identified in both national accounts and price statistics. The INSD compiles the national accounts following the harmonized WAEMU guidelines, which are in line with the $1993 S N A$. Annual data are available on GDP estimates by economic activity (19 industries) and by expenditure categories at current and constant (1985) prices, as well as by institutional sector accounts. Also, a general table of transactions and an overall balance of goods and services are available.

The quality of the national accounts estimates is affected by the scarcity of suitable data sources and by deficiencies in statistical practices. In particular, the informal sector is not properly captured, with estimates derived from limited informal sector surveys conducted in 1989 and 1996. Although included in the directory of industrial and commercial enterprises, most medium and small enterprises belonging to the "modern sector" fall short of submitting accounting statements or tax declarations. Other deficiencies revealed from GDDS metadata are the residual estimation of private household consumption in the absence of an adequate framework to validate data (i.e., supply-use tables), and the use of an outdated base year (1985) for constant price estimates. The country has completed, with TA from the Fund and other donors, the current price accounts for 2000 and revised the 1999 data. A work program aiming at improving the quality of the national accounts and producing estimates for missing years has been set up with AFRITAC West assistance. To this end, the INSD will receive further TA from the AFRISTAT and INSEE-France.

\footnotetext{
${ }^{23}$ Benin, Burkina Faso, Côte d'Ivoire, Guinea-Bissau, Mali, Niger, Senegal, and Togo.
} 
The consumer price index compiled by the INSD follows the methodology of the harmonized index adopted by the WAEMU member countries. The index only covers expenditures by households living in the capital. Further restrictions are the exclusion of non-African households, various types of purchased goods and services, as well as services of owneroccupied dwellings. The weight for the item "food, beverages, and tobacco" (33.9 percent of the total) is very low in comparison with neighboring countries. A possible explanation is that the survey from which the weights are taken did not cover a full year. There are planssubject to the availability of funding - to update the weights. Currently, the base year is 1996. When a product is unavailable, its price is presumed to remain unchanged for a period of up to three months, which is in conformity with the WAEMU methodology. However, best practice would impute a price change for these items on the basis of the prices recorded for closely related products. The software package used for calculating the consumer price index needs to be improved. There do not seem to be other major problems concerning the index, whose periodicity and timeliness meet SDDS requirements. The index is published by the INSD and is also available on the Central Bank of West African States (BCEAO) and AFRISTAT websites.

The authorities do not compile a producer price index or wholesale price index. According to plans for improvement posted on the DSBB, the development of these indices is not envisaged, even for the medium term.

\section{Government finance}

Annual data are published in the International Financial Statistics (IFS) through 2005 . No detailed monthly or quarterly data have been reported to STA for publication. The 2006 Government Finance Statistics Yearbook includes data for 2004 and 2005 that were for the first time reported in the format of the Government Finance Statistics Manual 2001 (GFSM 2001). The data cover budgetary operations only, but include a breakdown by function for 2004. In general, GFS compilation is constrained by a lack of coordination among fiscal agencies. The ROSC identified as areas for improvement the production of functional and ministerial breakdown of expenditure, extending the coverage of the TOFE to the general government, and basing compilation on the Treasury ledger. The above-mentioned areas benefited from the June-July 2007 FAD/AFRITAC West public finance management mission. It provided a medium-term strategy to improve budget management, furthered the progress on prior STA recommendations, and strongly encouraged the authorities to adopt functional classification of expenditure and other methods consistent with GFSM 2001.

\section{Monetary and financial statistics}

Preliminary monetary data are prepared by the national agency of the BCEAO and released officially with a lag of two to three months. Most of the problems in the monetary statistics are not specific to Burkina Faso, but affect all member countries of the WAEMU. For example, the BCEAO has encountered difficulties in estimating currency in circulation in each WAEMU member country due to large backlogs of unsorted banknotes held by the central bank in its various national agencies. Another problem has been the slower-thanexpected implementation of the new accounting system by banks since its introduction on January 1, 1996. These delays contribute substantially to the lag in reporting monetary statistics. 
The problems underlying delays in reporting of monetary statistics have not been resolved, despite technical assistance and additional measures to accelerate the bank note sorting operations to estimate currency in circulation in the WAEMU countries. In August 2005, the BCEAO informed STA of a change in the method to estimate currency in circulation in the WAEMU countries. The new method, based on updated sorting coefficients ("coefficients de tri"), has been applied backwards to time series from December 2003 and aims at improving the accuracy and timeliness of monetary statistics in the WAEMU countries. The African Department and STA await more information from the authorities to review the new methodology. Meanwhile, however, key monetary aggregates such as broad money, net foreign assets and other monetary indicators have undergone substantial revisions.

Following a technical assistance mission to the BCEAO headquarters in 2001, the authorities agreed on an action plan for the implementation of the Monetary and Financial Statistics Manual (MFSM) and on the introduction of an area-wide page for the WAEMU in the IFS; the latter was achieved in January 2003.

In August 2006, as part of the authorities' efforts to implement the MFSM's methodology, the BCEAO reported to STA monetary data for June 2006 for all member countries using Standardized Report Forms (1SR-central bank, 2SR-other depository corporations, and 5SRmonetary aggregates). These data were reviewed in STA and feedback was provided to the authorities. A response from the authorities is pending.

\section{Balance of payments}

The BCEAO national agency disseminates balance of payments statistics with a seven-month lag, in partial compliance with the recommendations of the GDDS, and annual international investment position data with an eighteen-month lag. Regarding trade data, the customs computer system (SYDONIA) was upgraded in 1999, and its implementation in the main border customs offices is complete; this allowed for better monitoring of import data and should improve the coverage of informal trade. Further improvement of services and transfers (especially workers' remittances) coverage is clearly linked to the future intensification of the contacts with reporting bodies. The 2003 data ROSC mission found that the response rate for the survey among industrial and commercial enterprises was only 40 percent. To address this, the mission recommended that more attention and resources be devoted to improve data collection. Updates for the IFS and the BOPSY since 2001 are pending.

In the financial account, the foreign assets of the private nonbank sector are well covered through the use of data from the Bank for International Settlements. The organization of annual surveys for the reporting of foreign direct investment transactions is still at a preliminary stage. The BCEAO authorities have indicated that they are looking forward to integrating two additional sources aimed at improving the quality of the balance of payments reports: the regional stock exchange transactions, and the firms' balance sheet database (centrale des bilans). They have also indicated that quarterly data derived from banking settlement reports will soon be used to assess the existing information. The balance of payments compilers receive payments statements every ten days; however, the information is not used in the compilation of the annual balance of payments statements, but rather to support data quality controls and to provide early information to the BCEAO authorities. 
The computer debt-management system software, SYGADE, developed by the United Nations Conference on Trade and Development, was introduced in 1999 and is fully operational. Information on debt disbursement has also been fully integrated with the expenditure-monitoring system. 


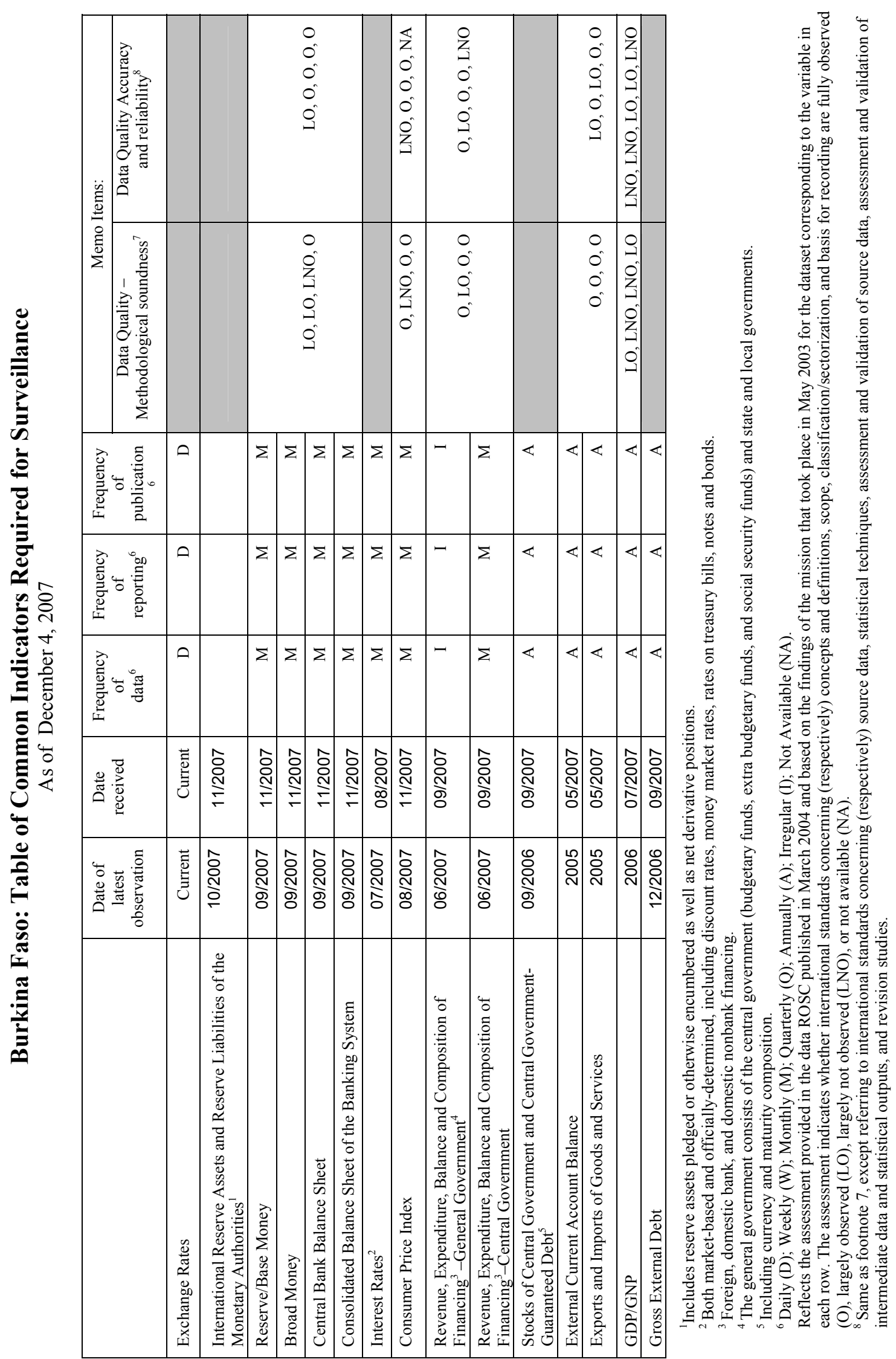




\section{INTERNATIONAL MONETARY FUND}

EXTERNAL

Public Information Notice

RELATIONS

DEPARTMENT

Public Information Notice (PIN) No. 08/02

International Monetary Fund

FOR IMMEDIATE RELEASE

$70019^{\text {th }}$ Street, NW

January 15, 2008

Washington, D. C. 20431 USA

\section{IMF Executive Board Concludes 2007 Article IV Consultation with Burkina Faso}

On January 9, 2008, the Executive Board of the International Monetary Fund (IMF) concluded the Article IV consultation with Burkina Faso. ${ }^{1}$

\section{Background}

Burkina Faso has made considerable progress towards macroeconomic stability over the past decade. Real GDP growth over the past 10 years was strong, averaging 6 percent annually, and inflation has been contained. Growth was broad based, supported recently in particular by the telecommunications and transportation sectors. Structural reforms and stability oriented macroeconomic policies have strengthened the market orientation of the economy and improved its flexibility. The gains from macroeconomic reforms have resulted in improvements in social indicators, with household survey poverty incidence reducing from 54.6 in 2000 to 46.4 percent in 2005. Nevertheless, Burkina Faso continues to rank among the poorest countries in the world, and reaching the Millennium Development Goals might be challenging.

Burkina Faso's macroeconomic performance in 2006 was better than projected during the last Article IV consultation despite a difficult external environment. Real GDP growth was around 5.5 percent and inflation fell below the WAEMU convergence criterion of 3 percent because of lower food prices. The current account improved as official current transfers

\footnotetext{
${ }^{1}$ Under Article IV of the IMF's Articles of Agreement, the IMF holds bilateral discussions with members, usually every year. A staff team visits the country, collects economic and financial information, and discusses with officials the country's economic developments and policies. On return to headquarters, the staff prepares a report, which forms the basis for discussion by the Executive Board. At the conclusion of the discussion, the Managing Director, as Chairman of the Board, summarizes the views of Executive Directors, and this summary is transmitted to the country's authorities.
}

Washington, D.C. 20431 • Telephone 202-623-7100 • Fax 202-623-6772 • www.imf.org 
exceeded expectations. Exports grew strongly partly because the fall in world cotton prices was not fully passed on to farmers. Fiscal policy loosened as planned, with the fiscal deficit (excluding grants) rising.

The overall positive macroeconomic performance reflects sound policy implementation, but also delayed adjustment to world cotton prices and additional debt relief. The limited pass through of world cotton prices shielded producers from the decline in world prices, keeping production - as well as exports and real GDP growth — high. The result was large financial losses at ginning companies; and the largest, partially-owned company, SOFITEX, had to be recapitalized at great cost to the budget. The authorities' policy to pass-through higher energy prices through automatic fuel price adjustments and a tariff increase for electricity were critical for adjusting to the oil price shock. Debt sustainability benefited from MDRI relief, which eased a key constraint on fiscal policy. The revenue effort remained low, including in comparison to other WAEMU countries; with lower-thanprojected revenues, the authorities also had to cut back expenditure increases.

Burkina Faso's medium-term outlook was impacted by an external shock relating to the balance of payments implications of weather-related declines in cotton exports and increased oil prices. This is expected to reduce growth, and has negatively affected the debt sustainability outlook. Real GDP growth is expected to decline to roughly 4.5 percent for 2007 though an expected increase in gold production could partly offset these effects. The current account deficit, excluding official transfers, will likely widen in 2007 and 2008. However, higher grant inflows, including disbursements from the Millennium Challenge Corporation (MCC), should help rein in the current account deficit, including transfers. The continued appreciation of the euro will make it harder for Burkina Faso to grow its exports base.

Ongoing structural reforms include steps to improve revenue performance. Domestic revenues are still low by regional standards, and measures focus on improving tax compliance and broadening the tax base. Reforms to improve tax administration include the computerization of the large taxpayer office, the removal of exemptions, and the streamlining of the tax code. The strengthening of public financial management is another focus of the authorities' reform program. In other areas, structural reforms are aimed at reducing constraints to the business environment, reduce corruption and improve international competitiveness. The authorities are also working with stakeholders on cotton sector reform.

\section{Executive Board Assessment}

Executive Directors commended the Burkinabè authorities for implementing strong policies in 2006 and 2007, in the context of a difficult macroeconomic environment. These policies have contributed to robust economic growth and low inflation.

Directors noted that the fall in international cotton prices, the appreciation of the euro, and rising oil prices pose challenges for sustaining growth and macroeconomic stability going 
forward. They welcomed the adjustment measures taken by the authorities in response to these challenges, and underscored the importance of maintaining a sound fiscal policy and pressing ahead with structural reforms to improve competitiveness, diversify the economy, and attract private investment. A prudent policy framework is especially important to improve external competitiveness.

Directors encouraged the authorities to reduce the fiscal deficit by increasing the revenueto-GDP ratio over the medium term. This will be necessary to raise priority spending while reducing the current account deficit and maintaining fiscal and external debt sustainability. In this connection, timely implementation of revenue administration and comprehensive tax policy measures will be crucial. Directors therefore welcomed the focus on revenueraising reforms in 2008 and encouraged early adoption of the planned tax policy reform. Directors also recommended against contracting new non-concessional borrowing, and stressed that the authorities should seek new assistance in the form of grants wherever possible.

Directors commended the authorities' efforts to strengthen public financial management and governance by improving budget preparation and execution, tightening expenditure controls, and tracking foreign-financed and poverty-reducing expenditure more closely. They welcomed in particular the steps taken to strengthen the government's audit capacity. Directors encouraged the authorities to further enhance transparency and expenditure prioritization, and welcomed their decision to join the Extractive Industries Transparency Initiative.

Directors commended the adoption of the new cotton producer price mechanism, which is a major step toward putting cotton ginning companies on a sustainable footing. They encouraged the authorities to liberalize the cotton sector and reduce the government's role, and to re-activate the automatic mechanism for adjusting domestic petroleum prices. Directors commended the substantial progress achieved in improving the business climate, and encouraged continued attention to improving governance, reducing rigidities in the labor market, and strengthening public institutions and infrastructure. Directors noted that, while the banking system appears to be stable, increasing vulnerabilities point to the need to strengthen the system further. The upcoming FSAP would be a good opportunity to help formulate the necessary reform measures.

Public Information Notices (PINs) form part of the IMF's efforts to promote transparency of the IMF's views and analysis of economic developments and policies. With the consent of the country (or countries) concerned, PINs are issued after Executive Board discussions of Article IV consultations with member countries, of its surveillance of developments at the regional level, of post-program monitoring, and of ex post assessments of member countries with longer-term program engagements. PINs are also issued after Executive Board discussions of general policy matters, unless otherwise decided by the Executive Board in a particular case. 


\section{Burkina Faso: Selected Economic Indicators, 2004-08}

\begin{tabular}{|c|c|c|c|c|c|}
\hline & 2004 & 2005 & $\begin{array}{l}2006 \\
\text { Est. }\end{array}$ & $\begin{array}{l}2007 \\
\text { Proj. }\end{array}$ & $\begin{array}{l}2008 \\
\text { Proj. }\end{array}$ \\
\hline & \multicolumn{5}{|c|}{$\begin{array}{l}\text { (Annual percentage change; unless otherwise } \\
\text { specified) }\end{array}$} \\
\hline \multicolumn{6}{|l|}{ GDP and prices } \\
\hline GDP at constant prices & 4.6 & 7.1 & 5.5 & 4.2 & 4.5 \\
\hline Consumer prices (annual average) & -0.4 & 6.4 & 2.4 & -0.7 & 2.0 \\
\hline \multicolumn{6}{|l|}{ Money and credit } \\
\hline Credit to the private sector ${ }^{1}$ & 6.1 & 14.9 & 11.2 & 9.6 & 7.4 \\
\hline Broad money (M2) & -7.2 & -3.8 & 10.2 & 15.8 & 6.2 \\
\hline \multicolumn{6}{|l|}{ External sector } \\
\hline Terms of trade & 11.0 & -23.9 & 3.7 & -2.9 & -6.1 \\
\hline Real effective exchange rate $(-=$ depreciation $)$ & -0.5 & 2.9 & 0.2 & $\ldots$ & $\ldots$ \\
\hline & \multicolumn{5}{|c|}{ (Percent of GDP; unless otherwise indicated) } \\
\hline \multicolumn{6}{|l|}{ Central government finances } \\
\hline Domestic revenue & 12.8 & 12.3 & 12.3 & 13.3 & 13.6 \\
\hline Total expenditure (commitment basis) & 21.4 & 21.7 & 22.9 & 26.7 & 26.2 \\
\hline Overall fiscal balance, excl. grants (commitments) & -8.6 & -9.4 & -10.7 & -13.4 & -12.7 \\
\hline Overall fiscal balance, incl. grants (commitments) ${ }^{2}$ & -4.3 & -4.9 & -5.1 & -6.2 & -5.4 \\
\hline \multicolumn{6}{|l|}{ External sector and debt indicators } \\
\hline Exports of goods and services & 10.7 & 10.0 & 11.7 & 10.7 & 10.3 \\
\hline Imports of goods and services & 24.3 & 24.6 & 24.6 & 25.4 & 26.6 \\
\hline Current account balance (excl. official transfers) & -13.4 & -14.6 & -12.5 & -14.1 & -16.0 \\
\hline Current account balance (incl. official transfers) & -10.4 & -11.4 & -9.6 & -10.1 & -12.2 \\
\hline External debt & 41.2 & 37.6 & 19.9 & 20.9 & 23.6 \\
\hline NPV of external debt & 18.1 & 19.0 & 10.6 & 11.5 & 13.1 \\
\hline NPV of external debt as percent of exports & 164.4 & 185.4 & 88.1 & 104.7 & 124.2 \\
\hline NPV of external debt as percent of revenues & 141.6 & 154.2 & 86.1 & 86.5 & 96.6 \\
\hline
\end{tabular}

Sources: Burkinabè authorities; and IMF staff estimates and projections.

${ }^{1}$ Percent of beginning-of-period broad money.

2 Excluding MDRI grants. 
Press Release No.08/04

FOR IMMEDIATE RELEASE

January 9, 2008
International Monetary Fund

Washington, D.C. 20431 USA

\section{IMF Executive Board Completes First Review Under PRGF Arrangement with Burkina Faso, Approves US\$5.5 Million Disbursement, and Increases Access Under the Arrangement}

The Executive Board of the International Monetary Fund (IMF) today completed the first review of Burkina Faso's economic performance under the three-year, SDR 6.02 million (about US\$9.5 million) Poverty Reduction and Growth Facility(PRGF) arrangement. The completion of the first review enables the release of an amount equivalent to SDR 3.51 million (about US\$5.5 million) bringing total disbursements under the arrangement to SDR 4.01 million (about US\$6.3 million). The Executive Board also approved an SDR 9.03 million (about US\$14.3 million) increase in access under the PRGF arrangement and granted waivers for the non- observance of two structural criteria pertaining to the adoption of the single customs document, and the notification of nonfilers by the tax administration on the basis of corrective actions taken.

The PRGF arrangement with Burkina Faso was approved on April 23, 2007 (see Press Release No. 07/77) to support the government's economic reform program for 2007-10.

The PRGF is the IMF's concessional facility for low-income countries. It is intended that PRGFsupported programs are based on country-owned poverty reduction strategies adopted in a participatory process involving civil society and development partners and articulated in a Poverty Reduction Strategy Paper (PRSP). This is intended to ensure that PRGF-supported programs are consistent with a comprehensive framework for macroeconomic, structural, and social policies to foster growth and reduce poverty. PRGF loans carry an annual interest rate of 0.5 percent and are repayable over 10 years with a $5 \frac{1}{2}$-year grace period on principal payments.

In commenting on the Executive Board's decision, Mr. Murilo Portugal, Deputy Managing Director and Acting Chair, stated:

"The Burkinabè authorities have maintained a strong policy performance in a difficult macroeconomic environment. The fall in international cotton prices, the appreciation of the euro, and rising oil prices posed severe challenges. The authorities addressed these challenges through 
appropriate adjustment measures, in particular by facilitating a pass through of international price movements. In this context, the new cotton producer price mechanism represents a major step toward putting cotton ginning companies on a sustainable footing. Resuming the automatic price adjustment mechanism for domestic petroleum prices will also be critical to facilitate economic adjustment to higher oil prices.

"In 2008, the expected decline in cotton exports and rise in oil imports will pose further external challenges. The Fund is helping Burkina Faso to meet the challenges by providing additional resources of SDR 9.03 million (about US\$13.9 million) in balance-of-payment support. Temporary factors, in particular adverse weather conditions, contribute to the expected widening of the current account deficit. However, the international price shocks also have a permanent component, and the authorities need to strengthen competitiveness in order to improve the long-run balance-ofpayments outlook.

"The planned fiscal stance for 2008 strikes an appropriate balance between adjusting to a deterioration in the debt sustainability outlook and protecting expenditures under adverse economic conditions. The authorities plan to focus in 2008 on further strengthening tax and customs administration, together with significant tax policy reforms. The availability of additional grants from the World Bank and the African Development Bank will make a significant contribution toward improving the debt sustainability outlook. This will need to be reinforced by policy measures, particularly a reduction in the fiscal deficit including grants over the medium term," Mr. Portugal said. 


\section{Statement by Laurean W. Rutayisire, Executive Director for Burkina Faso January 9, 2008}

On behalf of my Burkina Faso authorities, I would like to thank the Executive Board, Management and Staff for their continued support to Burkina Faso. My authorities are very grateful to staff for the constructive and high quality policy exchange over the past years and also for the fruitful discussions recently held in Ouagadougou.

In spite of a difficult external environment marked by low cotton prices, the country recorded a good macroeconomic performance in 2006, with a growth rate of $5 \frac{1}{2}$. Inflation fell below 3 percent, the convergence criterion of the monetary union. Even though revenue collection was adversely affected by slowdown in economic activity, the fiscal position was in line with expectations, owing to a higher inflow of grants and spending restraint. Exports increased strongly, but due to increases in the prices of oil imports and unfavorable international cotton prices, the current account deteriorated. The country's external position benefited from MDRI, which helped reduce by half the stock of external debt.

In order to enhance the country's resilience to exogenous shocks and make steady progress in poverty reduction and growth, my authorities have embarked on a comprehensive reform agenda within the framework of the PRGF, including tax and customs administration reforms, the adoption of a new public finance strategy aimed at yielding higher revenue collection and improving public financial management. In spending, my authorities efforts aimed at better tracking and prioritizing expenditures in order to increase growth enhancing and poverty reducing outlays. The agenda also involves the reform of the cotton sector, structural reforms to improve public sector efficiency, including through increased transparency and accountability and continued improvements in the business climate. In this latter respect, Burkina Faso's selection by the International Finance Corporation (IFC) as one of the best reformers in its latest Doing Business Report is a testimony of my authorities' commitment to- and ownership of-their ambitious reform agenda.

In view of the overall satisfactory program performance, amid adverse exogenous shocks, and given the commitment of my authorities to sound economic policies going forward, I request the Board's support for the completion of the first review of the PRGF-supported program and my authorities' request for an augmentation of access under the PRGF arrangement by 15 percent of quota, in order to smooth the adjustment of reserves. In addition, my authorities have already implemented the missed performance criterion on the implementation of a single customs declaration form and have initiated corrective actions to meet the missed criterion on tax administration as soon as possible.

\section{I- RECENT ECONOMIC DEVELOPMENTS}

Economic activity in 2007 has been buoyant, owing to my authorities steadfast implementation of a comprehensive policy response supplemented by an increased assistance from development partners. Inflation kept falling and has turned negative recently, even with the full pass-trough of increases in world oil prices to domestic prices. However, GDP growth projection has been reduced to $4 \frac{1}{4}$ percent, following the sharp reduction of cotton production. The production of cotton fell sharply, due to a decline in the floor price to cotton producers, a late announcement of the producer 
floor price, delayed payments from the cotton ginning company to producers- following banks refusal to extend to it further credit for the 2006-07 campaign, and a late rainfall.

On fiscal policy, my authorities maintained a prudent stance by restraining spending, while implementing reforms aimed at raising revenue, so as to create the fiscal space needed for priority spending. On the revenue side, key reforms were implemented, including in tax and custom administration and additional allocation of resources were made for audits and collection efforts. In tax administration, my authorities started using the functionalities of the tax administration computer system to automatically notify late tax filers. Further organizational improvements are being considered to ensure of the full implementation of the notification measure by end-January 2008. In customs administration, a single custom declaration form is being used since November 2007. Moreover, a computerized customs-specific valuation database is in place in all the computerized offices and will be used to improve the custom process. On spending, my authorities have limited spending to priority areas and one-off priority spending, such as the recapitalization of SOFITEX or the payment of VAT refund arrears. Further additional spending was restricted to foreign-financed capital spending.

My authorities took steps to reduce external competitiveness pressures following the increase of some real exchange rate indicators, including through structural reforms and a reduction of income taxes to a level in line with regional averages. They also took steps to increase the banking system soundness and promote financial development.

Structural reforms focused on reforming the cotton sector, efforts to fight corruption and improve the business climate. In order to ensure the financial viability of cotton ginning companies which registered significant losses, my authorities have completed the recapitalization of SOFITEX. Moreover, a new producer price mechanism for cotton was adopted, which will be in line with world prices. On governance and the fight against corruption, my authorities took steps to implement the national strategy for good governance, the Plan National de Bonne Gouvernance, $(P N B G)$. They streamlined the institutions involved under a new Autorité Supérieure de Contrôle $d^{\prime}$ Etat (ASCE) vested with more autonomy and powers to take legal action. On the business climate, my authorities have made significant progress, as reflected in Burkina Faso's rating improvement in IFC's Doing Business Report. They reduced the time required to register a company to 23 days, halved the cost of enforcing judgments, reduced property registration and transfer fees and introduced specialized commercial chambers to provide a one stop window for businesses.

\section{II- POLICY AND REFORM AGENDA FOR 2008}

My authorities plan to implement policies aimed at improving Burkina Faso's competitiveness, in order to diversify the sources of growth, increase the economy' resiliency to exogenous shocks and reduce poverty. In doing so, they will strive to preserve debt sustainability.

Fiscal policy will aim at creating the fiscal space required to make steady progress towards the millennium development goals, while preserving macroeconomic stability. This will require additional spending, especially in the face of increased social needs arising from the crisis in the cotton sector as well as recent flooding. Policy action in this respect is significantly complicated by 
the heightened debt sustainability concerns following the downturn in the cotton sector as this sector represents a significant share of Burkina Faso's exports. In view of these competing objectives, my authorities opted to maintain a prudent fiscal stance by targeting a deficit of 5.4 percent of GDP for 2008. To achieve their goal, my authorities plan to increase revenue collection, while prioritizing spending.

On revenue collection, they plan to further modernize tax administration, reinforce public financial management and implement an ambitious revenue administration reform agenda, in order to raise the revenue-to-GDP ratio by 0.2 percentage point in 2008. They also plan to front-load tax reforms aiming at broadening the tax base and preserving competitiveness, including by lowering corporate income tax to a level in line with regional standards. On the expenditure side, my authorities plan to increase health- and education-related spending as well as infrastructure outlays. They are committed to work with development partners, including the World Bank, to increase the efficiency of public spending, by conducting public expenditure reviews and project effectiveness analyses and by improving budget preparation and execution. Notably, they plan to take steps to better track expenditures and improve internal and external expenditure controls. They welcome technical assistance received from the IMF, especially the recent FAD mission, which will is a valuable input to their reform strategy.

On Structural Reforms, my authorities intend to finalize a strategy to reform and liberalize the cotton sector, improve governance and the business climate and promote financial sector development. They are closely consulting stakeholders, in order to define a comprehensive strategy for the cotton sector. The price smoothing fund (fonds de lissage) is expected to be finalized with the help of the Agence Française de Développement (AFD). However, key operating principles in this endeavor are already agreed upon, including self-financing, sustainability and transparency. As regards governance and the business climate, my authorities take good note of the reports of Transparency International, the World Bank's GICC and Doing Business Report, and the UNDP's Human Capital Index. While they had wished the reports' methodologies were improved to ensure comparability across countries at different income levels as well as consistency overtime, my authorities nevertheless consider the reports as informative and valuable inputs in identifying priority areas in need of improvement. On the upside, the reports show that, in areas within the Fund's core mandate, Burkina Faso's ranking is outstanding. Moreover, the country's rating in the IFC's Doing Business Report has significantly improved and ranked well on many indicators of quality of governance and corruption. Nonetheless my authorities reiterate their commitment to work closely with development partners to further improve on the current performance.

On governance, my authorities are committed to a steadfast implementation of the PNGB's which they hope will benefit from the comprehensive Governance and Anti-Corruption Diagnostics planned for 2008 with support from the World Bank. On the business climate, my authorities plan further reforms, in order to improve the economy's competitiveness, with an the aim of diversifying the sources of growth and increasing the role of the private sector in the economy. As for the

financial sector, my authorities will build on the results already achieved to continue to ensure the soundness of the banking system and reinforce the role of financial intermediation in promoting the private sector. 


\section{III- CONCLUSION}

My Burkina Faso authorities have demonstrated steadfast commitment to implementing the policies and reforms of their PRGF-supported program, even as they faced significant challenges. Although they expect many of the reforms to yield results in the medium-term, my authorities have made significant progress in tax and customs administration, taken steps to combat corruption, and continued to improve the business climate.

Going forward, my authorities are engaged in accelerating the pace of reforms, with the view to making progress towards achieving the Millennium Development Goals, while preserving macroeconomic stability. As recently as last week, President Compaoré reiterated his objective to significantly improve the country's human capital in 2008, which will contribute to progress towards meeting the MDGs and sustaining a broad-based economic growth. In view of the strong track record of my Burkinabè authorities in program implementation and their commitment to, and ownership of, sound economic policies and reforms, I will appreciate the Board's support to their requests. 